\title{
1994 Pacific Northwest Loads and Resources Study
}

This document is a product of the Energy Resources Development and Implementation Process:

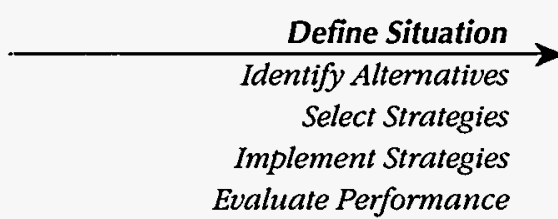

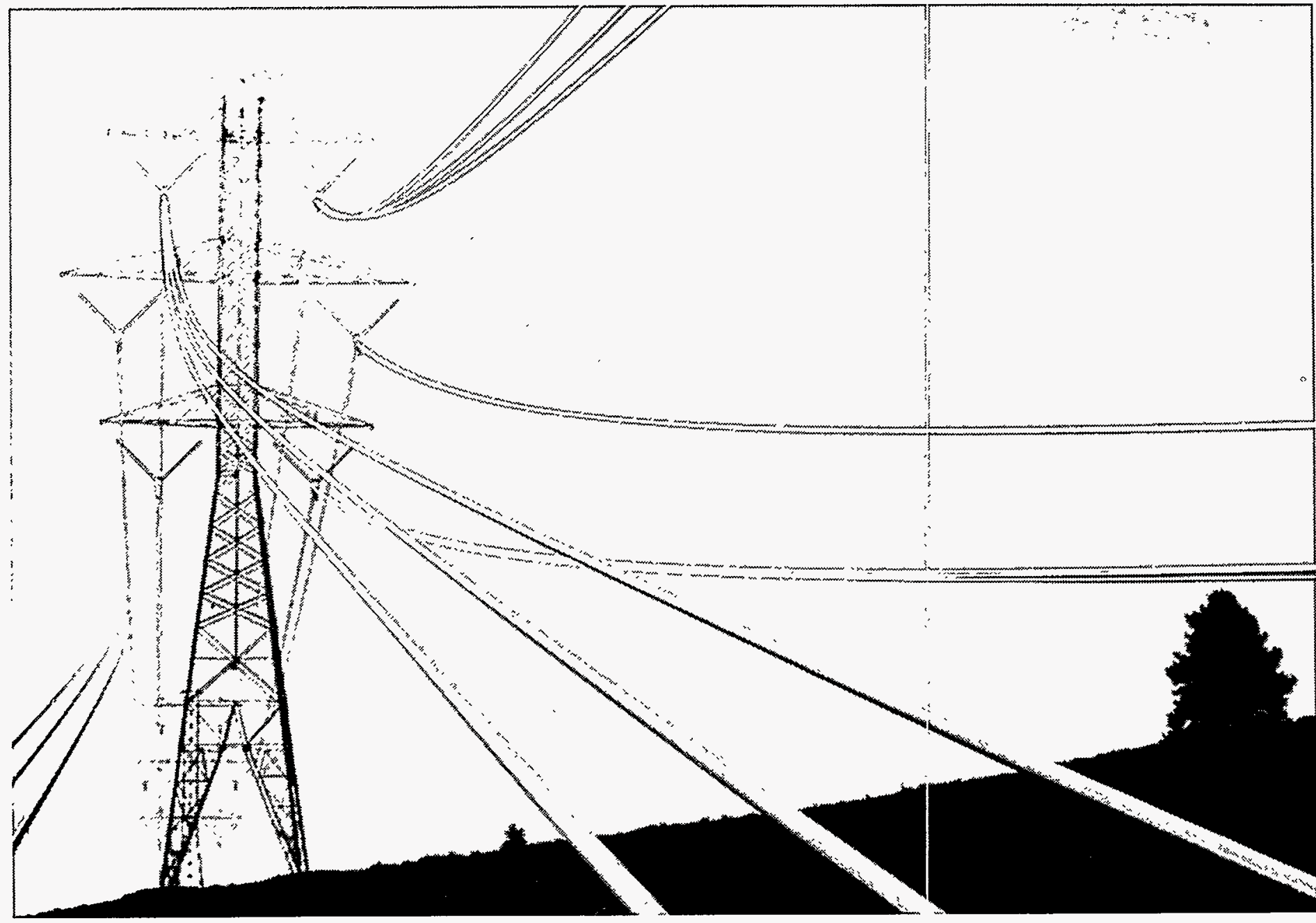

DISTRIBUTION OF THIS DOCUMENT IS UNLIMITED 


\section{Energy \\ Resources \\ Development \\ and \\ Implementation Process}

The Energy Resources Program contains all the steps needed to plan for and manage energy resources. This chart reflects that process, with major tasks for each step. Though we display a linear process, it is a simplification; many interactions among the stages take place.

Throughout the process, Bonneville asks

customers, the Northwest Power Planning Council, utility and environmental groups, the public and others for their advice and comment.

Customers Northwest Power Planning Council Utility and

Environmental Groups The Public

\section{Defining the}

To define the resource picture, Bonneville assesses its customers' power

requirements for the next 10 years and the supply of existing resources. Bonneville and the Northwest Power Planning Council publish energy demand forecasts, and analysts forecast how much power from existing resources will be avail-

able to meet projected uses. The difference must be met by new resources.
Resource Picture

\section{Identifying}

Alternatives

Analysts track potential resources and predict future supplies of conservation and generation resources, including imports and power exchanges. Analysts study all aspects of a resource: reliability, public opinion, cost, environmental impact, regulatory transmission and fuel constraints, and development time. Alternatives considered include opportunities for coordinating hydro system operations with Canada and for power purchases and transfers with Canadian and Southwest utilities.

\section{Selecting}

Using information on loads and resources, Bonneville weighs combinations of resources, their

consequences, and public comment to choose the most appropriate and costeffective resource strategy. The Resource Program documents this strategy.

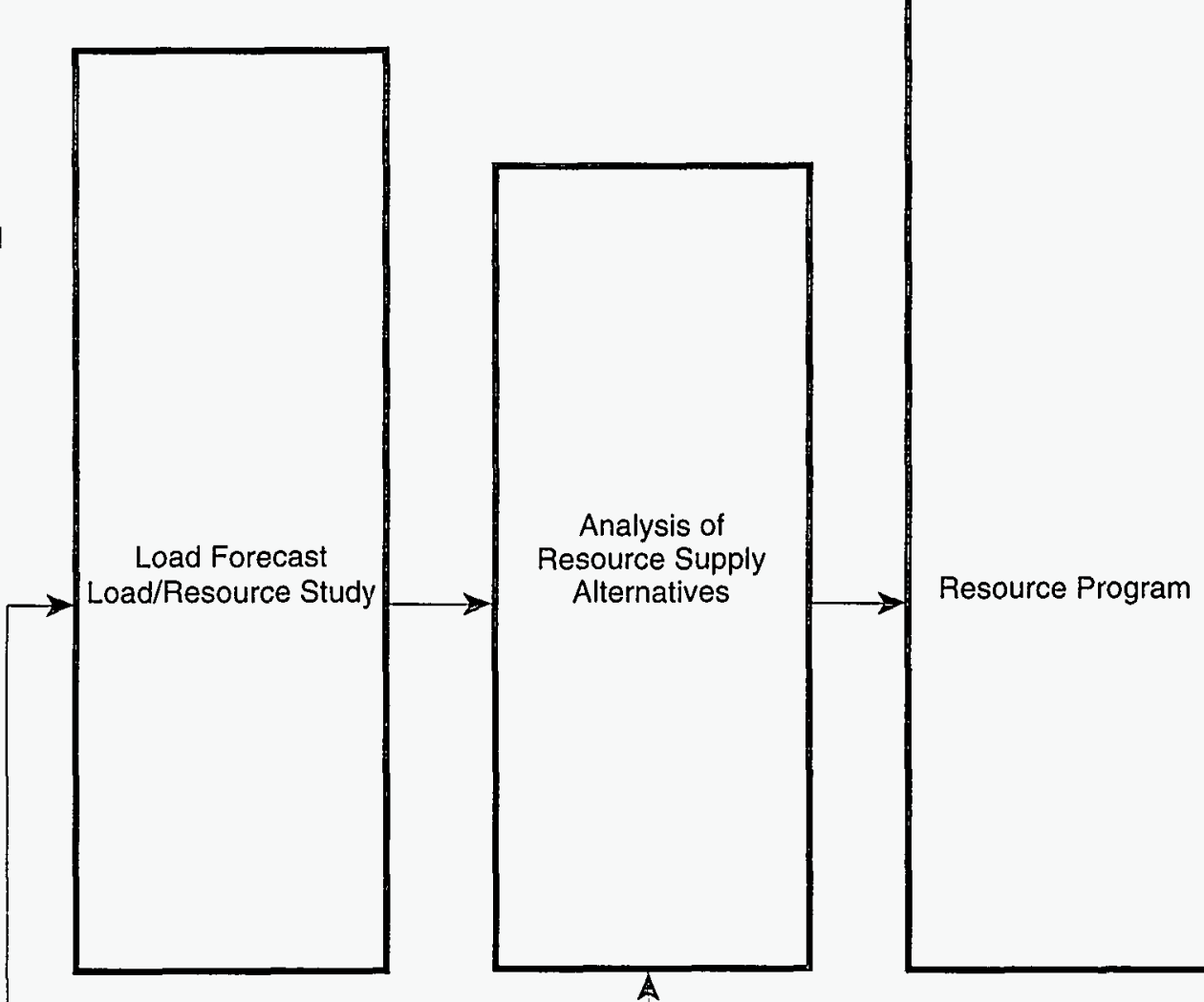

\section{Implementing} Strategies

Fulfilling the plans in the Resource Program is the next step. Working with utilities, resource developers, interest groups, the public, and others, Bonneville sponsors conservation and generation programs and projects. BPA conducts environmental reviews of programs and projects and also provides oversight for generation projects. The result: megawatts of electricity generated or saved for the region.

\section{Evaluating Performance}

How well did actions meet BPA's objectives? Answering this question through program evaluation provides information on energy

savings, energy production, costs and other measures of program quality. It is BPA's policy to evaluate all energy resource acquisitions. 


\section{PACIFIC NORTHWEST LOADS AND RESOURCES STUDY}

\section{DISCLAIMER}

This report was prepared as an account of work sponsored by an agency of the United States Government. Neither the United States Government nor any agency thereof, nor any of their employees, makes any warranty, express or implied, or assumes any legal liability or responsibility for the accuracy, completeness, or usefulness of any information, apparatus, product, or process disclosed, or represents that its use would not infringe privately owned rights. Reference herein to any specific commercial product, process, or service by trade name, trademark, manufacturer, or otherwise does not necessarily constitute or imply its endorsement, recommendation, or favoring by the United States Government or any agency thereof. The views and opinions of authors expressed herein do not necessarily state or reflect those of the United States Government or any agency thereof.

\section{MASTER}

\section{BONNEVILLE POWER ADMINISTRATIION December 1994}





\section{DISCLAIMER}

Portions of this document may be illegible in electronic image products. Images are produced from the best available original document. 


\section{ACKNOWLEDGMENTS}

Preparation of the annual Pacific Northwest loads and resources study is a complex, multidisciplinary effort. The managers of BPA's Marketing Support Group wish to acknowledge the team-BPA staff and others-whose diligence and dedication result in a reliable, high quality document.

Marketing Support Group

Market Forecasting \& Segment Analysis

Customer \& Competitor Analysis

Resource Optimization Group

Hydro system regulation study and data collection

Pacific Northwest Utilities Conference Cornmittee

Loads and resources data collection 


\section{TABLE OF CONTENTS}

Section I: Introduction

Pacific Northwest Planning Area

Regional Firm Resources 3

Analysis of Regional Firm Loads and Resources $\quad 5$

Analysis of Federal System Firm Loads and Resources

Nonfirm Resources $\quad 5$

Load Forecasting 6

Canadian Treaty Downstream Benefits 6

Canadian Entitlement to Columbia Storage Power Exchange (CSPE) · , 6

Through March 31, 2003

Canadian Entitlement to Canada, Beginning April 1, 1998

Major Sources of Uncertainty 8

Section III: Changes in the 1994 Pacific Northwest Loads and 9

Resources Study

Hydro Regulation Study

New Federal System Firm Resources . 9

Conservation Reductions 10

New Non-Generating Public Agency Resources $\quad 11$

Section IV: Federal System Analysis $\quad 13$

Federal System Firm Energy Loads $\quad 14$

Federal System Firm Peak Loads $\quad 15$

Existing Federal System Firm Resources · 17

Federal System Nonfirm Resources $\quad 20$

Federal System Firm Energy Surpluses/Deficits $\quad 20$

Section V: Planning to Meet Forecasted Deficits 23

Contractual Resource Options $\quad 23$

Non-Treaty Storage $\quad 24$

Federal System Firm Capacity Surpluses/Deficits $\quad 26$

Federal System Loads and Resources Comparison-Energy $\quad 27$

Federal System Loads and Resources Comparison-Capacity. $\quad 30$

Section Vl: Regional Analysis $\quad 33$

Regional Firm Energy Loads $\quad 33$

Regional Firm Peak Loads' $\quad 34$

Regional Firm Resources ～. $\quad 36$

Regional Nonfirm Resources $\quad 37$

Regional Firm Energy Surpluses/Deficits $\quad-\quad 37$

Regional Firm Capacity Surpluses/Deficits $\quad 39$ 
Section VII: Federal System Exhibits $\quad 41$

Federal System Critical Period Energy Analysis for 10 Operating Years . 43

Exhibit 1. Medium Load 44

Monthly Firm Energy Surpluses/Deficits Under Medium Loads for 1930

Water Conditions

Exhibit 2. OY 1995-96 48

Exhibit 3. OY 1999-2000 50

Exhibit 4. OY 2004-05 52

Federal System Monthly 50-Hour Capacity Surplus/Deficit Under Medium Loads for 1930 Water Conditions for 10 Operating Years 55

Exhibit 5. Medium Loads $\quad 56$

Federal System Monthly Capacity Analysis Under Medium Loads for 1930 Water Conditions

Exhibit 6. OY 1995-96

Exhibit 7. OY 1999-2000

Exhibit 8. OY 2004-05 62

Footnotes For Exhibits 1 through 8

Section VIII: Pacific Northwest Regional Exhibits $\quad 67$

Regional Critical Period Energy Analysis for 10 Operating Years: 69

Exhibit 9. Medium Loads 70

Regional Monthly Analysis Under Medium Loads for 1930 Water

$\begin{array}{ll}\text { Conditions } & 73\end{array}$

Exhibit 10. OY 1995-96 74

Exhibit 11. OY 1999-2000 _. 76

Exhibit 12. OY 2004-05 78

Regionäl Monthly 50-Hour Capacity Surplus/Deficit Under Medium Loads for 1930 Water Conditions for 10 Operating Years . 81

Exhibit 13. Medium Loads $\quad 82$

Regional Monthly Capacity Analysis Under Medium Loads for 1930 Water Conditions $\quad \ldots \quad \cdot \quad 83$

Exhibit 14. OY 1995-96 84

Exhibit 15. OY 1999-2000 86

Exhibit 16. OY 2004-05 . 88

Footnotes For Exhibits 9 through $16 \quad 90$

Section IX: Glossary ' 
Figure 1. Federal Firm Energy Loads, 1994 BPA Forecast

Figure 2. Federal Firm Peak Loads Under Extreme Weather Conditions, OY 1995-96, 1999-2000, and 2004-05, Medium Loads

Figure 3. Federal Firm Energy Surpluses/Deficits

Figure 4. Effect of May Water Budget and June Columbia River Flow Augmentation on the Federal Firm Energy Surplus

Figure 5. 1995-96 Federal Firm Capacity Surpluses/Deficits Under Extreme

Weather Conditions, Medium Loads

Figure 6. Regional Firm Loads, 1994 BPA Forecast

Figure 7. Regional Firm Peak Loads for OY 1995-96, 1999-2000, and 2004-05 Under Extreme Weather Conditions, Medium Loads

Figure 8. Regional Firm Energy Surpluses/Deficits

Figure 9. 1995-96 Regional Firm Capacity Surpluses/Under Extreme Weather Conditions, Medium Loads

\section{TABLES}

Table 1. Canadian Entitlement to Canada, Energy and Capacity Obligations Beginning April 1, 1998

Table 2. New Federal System Resources

Table 3. 1994 Pacific Northwest Loads and Resources Study, Cumulative Conservation Savings and Other Load Adjustments

Table 4. Federal System Hydroelectric Projects

Table 5. Non-Federally Owned BPA Resources and Contracts

Table 6. Federal System Firm Resources for OY 1995-96

Table 7. Federal System Firm Energy Surpluses/Deficits Assuming Existing Loads, Resources, and Contracts

Table 8. Existing Federal System Contractual Resource Options

Table 9. Changes in Federal System Firm Energy Surplus/Deficit

Table 10. Changes in Federal System 50-Hours-Per-Week Firm Capacity Surplus/Deficit for OY 1995-96

Table 11. Regional Firm Resources for OY 1995-96

Table 12. Regional Firm Energy Surpluses/Deficits Assuming Existing Contracts. 


\section{PACIFIC NORTHWEST LOADS AND RESOURCES STUDY}

\section{INTRODUCTION}

The 1994 Pacific Northwest Loads and Resources Study presented herein establishes a picture of how the agency is positioned today in its loads and resources balance. It is a snapshot of expected resource operation, contractual obligations, and rights. This study does not attempt to present or analyze future conservation or generation resource scenarios. What it does provide are base case assumptions from which scenarios encompassing a wide range of uncertainties about BPA's future may be evaluated.

The Loads and Resources Study is presented in two documents: 1) this summary of Federal system and Pacific Northwest region loads and resources and 2) a technical appendix detailing the loads and resources for each major Pacific Northwest generating utility. This analysis updates the 1993 Pacific Northwest Loads and Resources Study, published in December 1993.

In this loads and resources study, resource availability is compared with a range of forecasted electricity consumption. The forecasted future electricity demands-firm loads-are subtracted from the projected capability of existing and "contracted for" resources to determine whether BPA and the region will be surplus or deficit. If resources are greater than loads in any particular year or month, there is a surplus of energy and/or capacity, which BPA can sell to increase revenues. Conversely, if firm loads exceed available resources, there is a deficit of energy and/or capacity, and additional conservation, contract purchases, or generating resources will be needed to meet load growth.

The Pacific Northwest Loads and Resources Study analyzes the Pacific Northwest's projected loads and available generating resources in two parts: 1) the loads and resources of the Federal system, for which BPA is the marketing agency; and 2) the larger Pacific Northwest regional power system, which includes loads and resources in addition to the Federal system.

The loads and resources analysis in this study simulates the operation of the power system under the Pacific Northwest Coordination Agreement (PNCA) produced by the Pacific Northwest Coordinating Group.

This study presents the Federal system and regional analyses for the medium load forecast. This analysis projects the yearly average energy consumption and resource availability for Operating Years (OY) ${ }^{1}$ -1995-96 through 2004-05. The study shows the Federal system's and the region's monthly estimated maximum electricity

${ }^{1}$ Operating Year $(\mathrm{CY})$ is the 12-month period August 1 through July 31. For example OY 199596 is August 1, 1995 through July 31, 1996. 
demand, monthly energy demand, and monthly maximum generating capabilitycapacity-for .OY 1995-96, 1999-2000, and 2004-05. The Federal system and re- gional monthly capacity surpluses/deficits are summarized for 10 operating years.

The Federal system analysis is presented in Section IV, beginning on page 13. The analysis for the Pacific Northivest region is presented in Section VI, page 33.
A glossary of terms is included in Section IX, page 93 .

Additional copies of this summary, along with copies of the 1994 Pacific Northwest Loads and Resources Study Technical Appendix: Volume 1 (available February 1995) can be obtained from BPA's Public Involvement Office, toll-free, 1-800-6224520 . 


\section{BACKGROUND}

\section{Pacific Northwest Planning Area}

The Pacific Northwest regional planning area is defined by the Pacific Northwest Electric Power Planning and Conservation Act (Northwest Power Act), enacted in December 1980. It includes Oregon, Washington, Idaho, Montana west of the Continental Divide, and portions of $\mathrm{Ne}$ vada, Utah, and Wyoming that lie within the Columbia River drainage basin. In addition, any rural electric cooperative customers not in the geographic area described above that were served by BPA on the effective date of the Northwest Power Act are included in planning for resources to meet load.

\section{Regional Firm Resources}

The Pacific Northwest regional resources are comprised of generating resources operated or being built by Federal entities, public agencies, investor-owned utilities (IOUs), and independent power producers (IPPs). This study contains BPA's current projection of generation from existing resources and those future resources with signed contracts.

\section{Hydro Resources}

Energy Capability: BPA long-range planning is based on the firm energy capability of the hydro system. The firm hydro energy capability is the amount of power produced by these regional hydro resources in the historical sequence of low water conditions-called the critical period-re- corded for the Columbia River Basin. Currently, the critical period includes September 1928 through February 1932. This creates a 42-month critical period. The energy produced by the region's hydro projects during the critical period is calculated using the generation average. The hydro regulation study used in this analysis estimated the streamflows described in the National Marine Fisheries Service (NMFS) Draft Biological Opinion dated March 16, 1994. Besides including traditional streamflow requirements and May Water Budget, the NMFS Draft Biological Opinion included June Columbia River Flow Augmentation (CRFA) to further enhance fish passage. The June CRFA and May Water Budget fish mitigation measures are described below.

- May Water Budget was developed under the Northwest Power Planning Council's (Council) Columbia River Basin Fish and Wildlife Program. It includes the storage of 3.45 millionacre-feet (MAF) of water behind reservoirs for release in the springusually May.

- June CRFA was developed by the NMFS's Draft Biological Opinion dated March 16, 1994. It includes the storage of 3.5 MAF behind the reservoirs in Janurary through April 15 for release in late spring-usually June.

The critical period contains flows in the months of May and June that are in excess of those needed to meet the region's firm electric needs. To avoid overstating the Federal firm hydro energy generation re- 
sulting from implementing Water Budget flows and June CRFA, amounts of unisable generation resulting from the May and June flows are shown as reductions to Federal hydro generation. This is labeled "May Water Budget" and "June Columbia River Flow Augmentation" on the utilities' loads and resources tables. (See Section III, Changes in the 1994 Pacific Northwest Loads and Resources Study.) The regional hydro system generates approximately 12,700 average megawatts of firm energy under critical water conditions.

Capacity: The monthly instantaneous capacity of hydro projects is defined as the full-gate-flow maximum available generation at each project, based on the average monthly elevation resulting from 1929-30 water reservoir levels. BPA assumes 1929-30, water levels to estimate the regional hydro capacity because that year approximates a peaking capability that is consistent with the reliability criteria set forth in the Pacific Northwest Coordination Agreement.

The monthly instantaneous capacity is limited to 10 times the project's average monthly energy production because, at low or minimum water discharge, a plant may not be allowed to release enough water to achieve maximum capacity. The region's hydro projects have constraints and storage. limitations within any water condition.

BPA's planning projections reduce the estimated instantaneous hydro capacity to reflect a Federal sustained peaking level of 50 hours per week. This level provides estimated firm hydro capacity that can be maintained each day and continued for weeks at a time. This definition of firm capacity provides a better measure of resource capability. The hydro generation also is adjusted to allow for scheduled hydro maintenance, spinning reserves, and forced outage reserves.
Sections VII and VIII contain tables showing the amount of surplus capacity as defined above. These capacity tables, based on critical water conditions, should be used to determine the amount of capacity available to support firm sales. Capacity surplus values do not reflect potential nighttime return problems on the system. Nighttime return considerations are discussed under Federal System Firm Capacity Surpluses/Deficits, page 26.

Multiple-Use Planning: Pacific Northwest hydro projects have many uses besides power generation. The projects may provide flood control, supply irrigation for farming, assist in river navigation and recreation, and contribute to municipal water supplies. In addition, constraints also are in place to protect and enhance resident and anadromous fish populations. These nonpower uses place operating requirements on the reservoirs and limit hydroelectric power production. BPA's resource planning takes into account all presently known nonpower operating requirements in assessing regional hydro system capability.

The Corps of Engineers, Bureau of Reclamation, and BPA are, jointly preparing a System Operation Review (SOR) Environmental Impact Statement (EIS) on the operation of the Columbia River hydropower system. This EIS will allow the three Federal agencies to make decisions on (1) adopting a System Operating Strategy (SOS), (2) renewing the Pacific Northwest Coordination Agreement, (3) renegotiating five Canadian Entitlement allocation agreements, and (4) developing a means to periodically review and update the SOS.

The Council, BPA, and other Pacific Northwest entities will continue to evaluate new ways to enhance fisheries and wildlife. Future proposals could include additional amendments to the Council's Fish and Wildlife Program, recommendations arising from the System Operation Review, and/or 
implementation of additional programs in support of the Endangered Species Act. The impacts of future proposals are unknown. These proposals, however, most likely will increase non-power requirements on the hydro system and reduce operating flexibility, change the monthly shape of streamflows, and change the availability of sustained Federal capacity. Future studies will incorporate these impacts.

\section{Thermal Resources}

The expected output of regional thermal resources is based on the energy and capacity capabilities submitted to BPA by the project owners. The output of all thermal plants is reduced to allow for scheduled maintenance, spinning reserves, and forced outage reserves.

\section{Analysis of Regional Firm Loads and Resources}

The Pacific Northwest regional analysis contains the Federal system loads and resources, plus non-Federal regional loads, contractual obligations, and generating resources. The region has three load groups: Federal system, generating public agencies, and IOUs. The regional hydro resources are owned and operated by various Federal entities, public agencies, and IOUs. The regional thermal generating resources, fueled by biomass, coal, natural gas, oil, or nuclear power, are owned and operated by various regional entities.

The regional analysis is presented in Section VI, beginning on page 33 .

\section{Analysis of Federal System Firm Loads and Resources}

BPA is a power. marketing agency, responsible for acquiring and delivering sufficient power to serve the needs of its cus- tomers. BPA does not own generating resources. BPA's customer loads and contractual obligations, combined with the resources from which BPA acquires the power it sells, are collectively referred to as the Federal system. BPA owns and operates the primary transmission grid-more than 14,700 circuit miles of power lines-in the Pacific Northwest.

The Federal system loads are made up of BPA's sales to other Federal agencies, the region's public agencies, several -direct service industrial (DSI) customers, and other contractual obligations to deliver power. This study includes only the firm DSI loads; interruptible DSI loads are not served from firm resources. Operation of the Federal system under the PNCA serves interruptible DSI loads on a semi-firm basis, using various operational procedures.

The hydro resources of the Federal system include 30 dams owned and operated by the United States Bureau of Reclamation (USBR) and the United States Army Corps of Engineers (COE), plus hydroelectric projects owned by the city of Idaho Falls, Washington Public Power Supply System (WPPSS), and Lewis County Public Utility District (PUD). Added as a new resource in this year's study is BPA's purchase of firm power from Northern Wasco's McNary Fishway hydro unit. BPA. has the exclusive right to sell power generated by USBR and COE hydroelectric projects. BPA also markets the thermal generation from the WNP-2 nuclear plant, operated by WPPSS.

The Federal system analysis is shown in Section IV, beginning on page 13 .

\section{Nonfirm Resources}

Federal system firm resource capability is estimated using critical water flows. The regional hydro system, however, historically has experienced precipitation levels 
that produced greater-than-critical-period flows. This excess water is used to produce nonfirm energy.

BPA's loads and resources balance does not include nonfirm energy. Nonfirm energy could increase regional generation by about 3,800 to 4,200 average megawatts annually when averaged over 50 years of historical water flows. The Federal share of this nonfirm energy is about 2,300 to 2,600 average megawatts based on 50 years of hydro flow data. Capacity generally is available to support nonfirm energy sales.

Nonfirm energy in the Northwest is generally used to serve the interruptible portion of BPA's DSI load and displace higher cost thermal resources, and is stored for later release during the Columbia River's augmented flows in the month of June. Nonfirm energy in excess of Northwest needs is available for export to other markets.

\section{Load Forecasting}

The load/resource analysis used BPA's medium case load forecast that was prepared in August 1994. Loads for each of the following customer groups were estimated separately: non-generating public agencies, generating public agencies, aluminum DSIs, non-aluminum DSIs, IOUs, Federal agencies, and the USBR. In general, BPA's load forecasts are designed to respond to and reflect factors such as employment, electricity prices; aluminum prices, smelter production costs, and planned conservation actions. The IOU load forecast was produced by BPA in 1993. This forecast updated the economic assumptions from the 1991 joint BPA/Council forecast and also used a modified version of the residential sector.

\section{Canadian Treaty Downstream Benefits}

Obligations under the Columbia River Treaty will change during the study period. This treaty between the United States and Canada enhanced the use of storage in the Columbia River Basin. The treaty and treaty projects provide downstream benefits by increasing the firm power generating capability of U.S. hydro projects. Under the terms of the agreement, the downstream power benefits are shared equally between the two countries as determined by a joint Annual Operating Plan.

\section{Canadian Entitlement to Columbia Storage Power Exchange (CSPE) Through March 31, 2003}

Canada agreed to sell its share of the downstream power benefits, called the Canadian Entitlement, for 30-year periods beginning with the completion of each of the three Canadian Treaty Projects (Mica, Duncan, and Arrow). The Canadian Entitlement was sold to the Columbia Storage Power Exchange (CSPE), a Pacific Northwest corporation that was formed to sell the Canadian benefits to participating Pacific Northwest utilities. The Canadian Entitlement sale to CSPE begins to expire April 1, 1998, 30 years after the completion of the first Treaty Project, and expires March 31,2003. 
Canadian Entitlement to Canada, Beginning April 1, 1998

A portion of the Canadian share of downstream power benefits will begin to return to Canada April 1, 1998, 30 years after the first Treaty Project was completed. All remaining Canadian downstream power benefits will revert to Canada by April 1, 2003,. 30 years after the third Treaty Project was completed. This analy sis assumes Canadian Entitlement deliveries to Canada under the basic principles of the Memorandum of Agreement between British Columbia and the United States negotiated during the fall of 1994. These principles changed the participating U.S. entities' capacity and energy obligations to Canada. The Canadian Entitlement Canada delivery starting April 1,1998, is included in each participating utility's loads and resources balance. BPA delivers the total Canadian Entitlement, shown in Table 1, and it is included as a Federal export.

\section{Table 1}

\section{Canadian Entitlement to Canada}

Energy and Capacity Obligations Beginning April 1, 1998

Energy in Average Megawatts

\begin{tabular}{|l|r|r|r|r|r|r|r|r|r|r|}
\hline OPERATING YEAR & \multicolumn{1}{|c|}{1996} & 1997 & 1998 & 1999 & 2000 & 2001 & 2002 & 2003 & 2004 & 2005 \\
\hline $\begin{array}{l}\text { Investor-Owned } \\
\text { Utilities }\end{array}$ & 0 & 0 & 2 & 21 & 47 & 48 & 47 & 57 & 81 & 80 \\
\hline Public Agencies & 0 & 0 & 3 & 15 & 31 & 30 & 30 & 40 & 57 & 57 \\
\hline Federal System & 0 & 0 & 12 & 101 & 222 & 221 & 220 & 278 & 392 & 391 \\
\hline $\begin{array}{l}\text { TOTAL ENERGY } \\
\text { OBLIGATION }\end{array}$ & 0 & 0 & 17 & 137 & 300 & 299 & 297 & 375 & 530 & 528 \\
\hline
\end{tabular}

January Capacity in Megawatts

\begin{tabular}{|l|r|r|r|r|r|r|r|r|r|r|}
\hline OPERATING YEAR & \multicolumn{1}{|c|}{1996} & 1997 & 1998 & 1999 & 2000 & 2001 & 2002 & 2003 & 2004 & 2005 \\
\hline $\begin{array}{l}\text { Investor-Owned } \\
\text { Utilities }\end{array}$ & 0 & 0 & 0 & 0 & 0 & 0 & 0 & 0 & 0 & 0 \\
\hline Public Agencies & 0 & 0 & 0 & 0 & 0 & 0 & 0 & 0 & 0 & 0 \\
\hline Federal System & 0 & 0 & 0 & 86 & 521 & 521 & 521 & 521 & 950 & 950 \\
\hline $\begin{array}{l}\text { TOTAL CAPACITY } \\
\text { OBLIGATION }\end{array}$ & 0 & 0 & 0 & 86 & 521 & 521 & 521 & 521 & 950 & 950 \\
\hline
\end{tabular}




\section{Major Sources of Uncertainty}

\section{Loads and Resources Uncertainty}

Future Federal system and regional firm surpluses/deficits are subject to a number of uncertainties over the 10-year study period. These uncertainties include:

- BPA's future marketing efforts and/or revised resources acquisition, including conservation, under BPA's impending business plan;

- Possible increases in resource acquisitions by BPA's public agency customers, which would decrease their purchases from BPA;

- Deviation from the forecasted rate of load growth;

- Changes in conservation program levels, including model conservation standards (MCS) implementation

- Failure of existing or contracted generating resources to operate at anticipated times and levels; and

- Changes in existing hydro system operation in response to programs developed to address the Endangered Species Act or other environmental considerations.

These uncertainties could affect both the size of projected surpluses or deficits and the times at which they occur.

\section{Contractual Uncertainty}

BPA's contractual obligation to serve future regional load growth is uncertain because there is no precise way to predict the amount of load growth regional utilities will place on BPA in coming years. This study assumes that the following contracts, though they are subject to change as noted, will extend throughout the 10-year study period. What occurs when these contracts expire, which will be at varying times during the 10-year study period; may affect the Federal system and regional loads and resources balances:

- BPA's power sales contracts with its DSI, public agency, and IOU customers expire June 30,2001 . Renegotiation of these contracts may result in new or different Federal obligations.

- The Pacific Northwest Coordination Agreement will expire June 30, 2003. BPA expects this agreement, which coordinates operation of the Pacific Northwest power system and that of Canada, will be replaced with a new agreement. The provisions of a new agreement may be different from the existing agreement. 


\section{CHANGES IN THE 1994 PACIFIC NORTHWEST LOADS AND RESOURCES S'TUDY}

This section describes the major changes in the assumptions of the 1994 Pacific Northwest Loads and Resources Study compared to the 1993 study. Other changes are reflected in the data for each utility contained in the 1994 Pacific Northwest Loads and Resources Study Technical Appendix.

\section{Hydro Regulation Study}

This study incorporates the hydro requirements contained in the NMFS Draft Biological Opinion dated March 16, 1994.

In addition to all current flow requirements, the NMFS Draft Biological Opinion includes June CRFA, providing 3.5 MAF of storage behind the reservoirs' dams, January through April 15, for release in June to enhance fish passage. This creates energy deficits in the winter during critical water conditions and potential power purchases. Under better water conditions, natural runoffs provide enough storage to meet CRFA requirements. CRFA reduced the Federal system critical period energy by 217 average megawatts when compared to last year's study. During the 42-month critical period, June CRFA with the
May Water Budget produces generation for the Federal system that is beyond normal amounts that can be marketed in that month. June CRFA energy, as well as May Water Budget, are included as reductions to the Federal system loads and resources analysis. In last year's study, CRFA was assumed to be handled operationally using non-firm energy and power purchases.

\section{New Federal System Firm Resources}

BPA contracted for several resources for use in meeting long-range loads.

There are four new Federal non-utility generating (NUG) resources which provide up to 184 average megawatts over the study period. These are shown in Table 2, page 10 . The energy produced by these projects is shown as Federal NUGs on line 36 in Exhibits 1 through 4, pages 43 through 53. Additionally, Table 2 lists up to 96 average megawatts of new non-utility generation contracted for by BPA since last year's analysis. 


\section{Table 2}

\section{New Federal System Resources}

\begin{tabular}{|l|c|c|c|}
\hline Name & Type & On-Line Date & Energy (aMW) \\
\hline New Federal Non-Utility Generation: & October-1996 & 124 \\
\hline Tenaska \#2 (Frederickson) & Combustion Turbine & October 1996 & 50 \\
\hline SDS Lumber & Cogeneration & January 1996 & 1 \\
\hline Clearwater - & Hydro & January 1996 & 9 \\
\hline Wyoming Wind (BPA share) & Wind & $\mathbf{1 8 4}$ \\
\hline \hline
\end{tabular}

New BPA-Contracted Non-Utility Generation:

\begin{tabular}{|l|c|c|c|}
\hline Wauna & Cogeneration & October 1996 & 29 \\
\hline Newberry & Geothermal & November 1997 & 30 \\
\hline Glass Mountain (Vale) & Geothermal & October 1998 & 28 \\
\hline Columbia Hills Wind & Wind & January 1996 & 9 \\
\hline \hline \multicolumn{2}{|l}{ Total BPA-Contracted Non-Utility Generation } \\
\hline
\end{tabular}

\section{Conservation Reductions}

This analysis assumes that energy consumers will change their consumption in response to changes in electricity price. The 1994 BPA load forecast was reduced for the following conservation program types and due to conservation reinvention.

1. As in previous loads and resources studies, the load forecast was reduced for conventional programmatic conservation measures. These measures are currentlybudgeted BPA-sponsored programs and are counted as a reduction to loads. These programs include residential, commercial, industrial, and agricultural programmatic conservation, and targeted acquisitions. They are detailed on line 1 of Table 3 , page 12.

2. This year's study includes other BPAfunded conservation and load reductions due to conservation reinvention programs and changes in the competitive power marketing business. This is a new reduction to the 1994 study and includes the following:

- Additional performance-based conservation billing credits contracts, consistent with the Regional Act's billing credit provisions, resulting from responses to a BPA.request for proposals;

- Competitive acquisitions, which are performance-based conservation purchase arrangements resulting from responses to BPA's Competitive Acquisition request for proposals;

- Power plants, which includes contracts BPA has with individual utilities and with consortia of utilities to use third party financing toward comprehensive utility conservation programs;

- Tiered rate conservation response due to retail consumer changes in 
retail rate structure resulting from BPA implementing tiered rates;

- Market transformation reductions due to lasting changes in the market that result from the penetration of energy efficient technologies and practices; and

- Non-MCS codes and standards, which are conservation means not currently included in MCS.

These programs are detailed on line 2 in Table 3.

Table 3, line 3, shows additional customer-funded conservation programs. These conservation measures are not fully defined and are not included as a load reduction. They are shown to help illustrate the total cumulative conservation savings within the Pacific Northwest region, following guidelines set in the 1994 BPA Business Plan and the Council's regional power iplan. Total cumulative conservation savings are shown in Table 3 , line 4.

\section{New Non-Generating Public Agency Resources}

This year's analysis contains new public agency resources including Clark County PUD's Cogentrix (202 average megawatts) and Grays Harbor: PUD's share of Centralia (50 average mega.watts). 


\section{Table 3}

1994 Pacific Northwest Loads and Resources Study Cumulative Conservation Savings and Other Load Adjustments

Energy in Average Megawatts

\begin{tabular}{|c|c|c|c|c|c|c|c|c|c|c|}
\hline Operating Year ${ }^{1}$ & 1996 & 1997 & 1998 & 1999 & 2000 & 2001 & 2002 & 2003 & 2004 & 2005 \\
\hline \multicolumn{11}{|c|}{ 1. Conventional ConserVATION REDUCTIONS ACCOUNTED FOR IN THE 1994 BPA LOAD FoRECAST } \\
\hline \multicolumn{11}{|l|}{ Programmatic Conservation } \\
\hline Residential & 88.5 & 88.5 & 88.5 & 88.5 & 88.5 & 88.5 & 88.5 & 88.5 & 88.5 & 88.5 \\
\hline Commercial & 46.2 & 46.2 & 46.2 & 46.2 & 46.2 & 46.2 & 46.2 & 46.2 & 46.2 & 46.2 \\
\hline Industrial & 36.2 & 36.2 & 36.2 & 36.2 & 36.2 & 36.2 & 36.2 & 36.2 & 36.2 & 36.2 \\
\hline Agricultural & 8.1 & 8.1 & 8.1 & 8.1 & 8.1 & 8.1 & $\overline{8.1}$ & 8.1 & 8.1 & 8.1 \\
\hline SUB-TOTAL & 179.0 & 179.0 & 179.0 & 179.0 & 179.0 & 179.0 & 179.0 & 179.0 & 179.0 & 179.0 \\
\hline Targeted Acquisitions (TAP) & 31.1 & 33.9 & 35.2 & 36.0 & 36.9 & 37.4 & 37.6 & 37.9 & 37.9 & 37.9 \\
\hline $\begin{array}{l}\text { TOTAL CONSERVATION REDUCTIONS IN THE LOAD } \\
\text { FORECAST }\end{array}$ & 210.1 & 212.9 & 214.2 & 215.0 & 215.9 & 216.4 & 216.6 & 216.9 & 216.9 & 216.9 \\
\hline
\end{tabular}

\begin{tabular}{|c|c|c|c|c|c|c|c|c|c|c|}
\hline \multicolumn{11}{|c|}{ 2. ADDITIONAL CONSERVATION \& CONSERVATION REINVENTION LOAD REDUCTIONS ACCOUNTED FOR IN THE 1994 BPA LOAD FORECAST } \\
\hline Billing Credits & 0.2 & .0 .2 & 0.2 & 0.2 & 0.2 & 0.2 & 0.2 & 0.2 & 0.2 & 0.2 \\
\hline Competitive Acquisitions & 18.7 & 23.4 & 26.6 & 27.8 & 28.4 & 28.9 & 29.1 & 29.4 & 29.4 & 29.4 \\
\hline Power Plants & 53.2 & 56.5 & 56.5 & 56.5 & 56.5 & 56.5 & 56.5 & 56.5 & 56.5 & 56.5 \\
\hline Assumed Tiered Rate Response & 4.0 & 8.0 & 12.0 & 17.0 & 23.0 & 30.0 & 38.0 & 47.0 & 47.0 & 47.0 \\
\hline Assumed Market Transformation & 1.0 & 3.0 & 6.0 & 10.0 & 14.0 & 18.0 & 23.0 & 27.0 & 27.0 & 27.0 \\
\hline Adjustments for Codes \& Standards & 13.0 & 19.0 & 25.0 & 31.0 & 37.0 & 43.0 & 49.0 & 55.0 & 55.0 & 55.0 \\
\hline $\begin{array}{l}\text { TOTAL ADDITIONAL LOAD REDUCTIONS IN THE LOAD } \\
\text { FORECAST }\end{array}$ & 300.2 & 323.0 & 340.5 & 357.5 & 375.0 & 393.0 & 412.4 & 432.0 & 432.0 & 432.0 \\
\hline
\end{tabular}

3. Additional Customer Funded Conservation not Included in the 1994 BPA Load Forecast

\begin{tabular}{|l|l|l|l|l|l|l|l|l|l|l|}
\hline Customer-Funded Conservation & 18.0 & 38.0 & 65.0 & 95.0 & 125.0 & 156.0 & 189.0 & 223.0 & 223.0 & 223.0 \\
\hline
\end{tabular}

\begin{tabular}{|c|c|c|c|c|c|c|c|c|c|c|}
\hline 4. TOTAL PROJECTED CONSERVATION SAVINGS ${ }^{2}$ & 318.2 & 361.0 & 405.5 & 452.5 & 500.0 & 549.0 & 601.4 & 655.0 & 655.0 & 655.0 \\
\hline
\end{tabular}

The conservation data is cumulative since 1992.

Price induced conservation is not included in these conservation savings because the load forecast already accounts for price induced conservation.

1 Operating Year (OY) is the 12-month period August 1 through July.31. For example OY 1995-96 is August 1, 1995 through July 31, 1996.

${ }^{2}$ Total conservation savings consistent with the 1994 BPA Business Plan. 


\section{FEDERAL SYSTEM ANALYSIS}

This study provides base case assumptions from which scenarios encompassing a wide range of uncertainties about BPA's future may be evaluated. It incorporates only load forecast uncertainty and capacity availability under extreme weather conditions.

The Federal system loads and resources analysis is based on the following assumptions:

- Capacity surplus/deficit values do not reflect potential nighttime return problems on the Federal system;

- The region experiences medium load growth;

- The Pacific Northwest Coordination Agreement, which expires June 30, 2003 , is replaced with a like agreement;

- BPA's power sales contracts with Pacific Northwest Federal and public agencies, IOUs, and DSIs, which expire June 30, 2001, are renewed with like agreements;

- All existing Federal contractual arrangements not included under $\mathrm{Pa}$ cific Northwest power sales contracts expire and are not renewed;

- Federal surplus firm power sales to the cities of Burbank, Glendale, and Pasadena, and the Southern California Edison Company (SCE), are shown as power sales through their expiration.

- BPA's surplus firm power sale to $\mathrm{M}-\mathrm{S}-\mathrm{R}$ remains a power sale through
October 31,2009 , then converts to a capacity/energy exchange until it expires;

- BPA's surplus firm power sale to Puget Sound Power and Light terminates and: converts to a seasonal power exchange beginning in OY 2001-02, per the terms of the contract;

- BPA delivers 150. megawatts of surplus peak capacity to PGE through June 30, 2001.

- A surplus capacity contract of 50 megawatts with WWP continues through September 30, 2010;

- Sustained capacity limits are 50 hours per week.

- BPA's capacity sale of 1,100 peak megawatts to PacifiCorp (formerly doing business as Pacific Power \& Light, a.k.a., PP\&L) continues through August 31, 2001;

- BPA serves all of the Pacific Northwest public agencies' net firm load requirements not served by their own resources;

- Extreme vreather adjustments during the months of November through February. These adjustments vary monthly fiom 1,400 to 1,800 peak megawatts under the medium load forecast; and

- The IOUs do not make new longterm BPA purchases under their power sales contracts. 
The assumption that there will be no long-term power -purchases by BPA's IOU customers is due to the uncertainty of the IOUs' intentions. BPA believes this assumption is reasonable because: 1) The IOUs have not informed BPA to the contrary; and 2) the IOU power sales contracts contain a 7-year notice requirement that provides BPA adequate time to secure resources to meet increased IOU obligations. Currently, no IOU is placing an obligation on BPA.

PGE was purchasing capacity of 150 megawatts through June 30,1999 , under its power sales contract. This contract. has since been revised and the capacity now is purchased under the surplus peak rate schedule through June 30, 2000.

\section{Federal System Firm Energy Loads}

The Federal system firm loads include BPA's firm DSI load, ${ }^{1}$ sales to Federal agencies, current obligations to regional

${ }^{1}$ This study includes only firm DSI loads; interruptible DSI loads are not served from firm resources. Operation of the Federal system under the PNCA serves the interruptible DSI loads on a semi-firm basis using various mechanisms. public agencies and IOUs under their power sales contracts, and other inter- and intra-regional contractual obligations.

The Federal system firm energy loads under the medium load forecast for OY 1995-96 through 2004-05 are shown in Figure 1. The methods and assumptions used to complete this year's range of forecasts are discussed under Load Forecasting, page 6 .

The Federal loads include all intra-regional contracts made within the Pacific Northwest, called contracts out, and interregional contracts or exports of firm surplus power to Southwest utilities. The Federal firm energy loads under the medium load forecast are presented on line 8 of Exhibit 1, page 44, and monthly for the medium load forecast for OY 1995-96, 1999-2000, and 2004-05 assuming 1930 water conditions in Exhibits 2 through 4, pages 48 through 53 . 


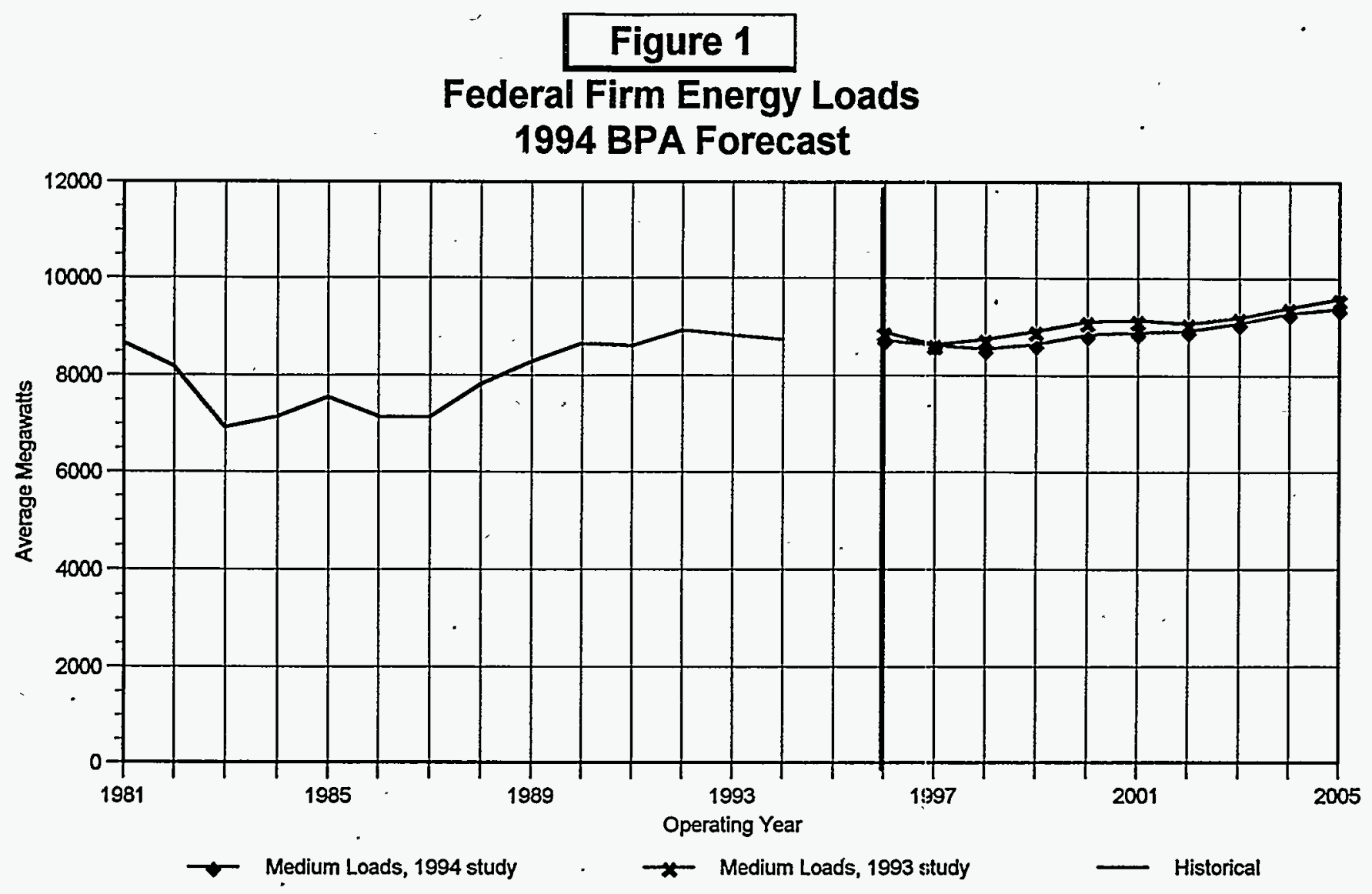

MPMO: 1294

\section{Federal System Firm Peak Loads}

Figure 2, page 16, shows the Federal firm peak loads for OY 1995-96, 19992000, and 2004-05 under the medium load forecast. Figure 4 shows the Federal firm peak loads under the medium load forecast for OY 1995-96. The figures show the expected 1-hour monthly demand under the 1994 BPA load forecast, and include extreme weather adjustments. Extreme weather conditions were assumed for the months of November through February and estimate a 5-percent probability that the actual peak load will be exceeded. The extreme weather adjustment includes possible increased obligations on BPA by the public agencies during extreme weather conditions. In the remaining months of
March through October, the peak loads estimate normal weather conditions with a 50-percent probability that the actual peak load will be exceeded. The peak load projections are reduced by a diversity component to address the fact that all peak electrical demands do not occur simultaneously throughout the region.

This year's study includes the following BPA contract:

- A capacity sale of 1,100 megawatts to PacifiCorp through August 31, 2011; and

- A sale of 150 peak capacity megawatts to PGE through June 30, 2000.

This study assumes that public agencies will purchase capacity from BPA under their power sales contracts to meet peak loads not served by their own resources. 
The monthly Federal firm peak loads are presented on line 15 , and the monthly extreme weather obligations are presented on lines 47 and 50 of Exhibits 6 through 8, pages 58 through 63 , for the medium load forecast for OY 1995-96, 1999-2000, and 2004-05, assuming Federal obligations under 1930 water conditions.

\section{Figure 2}

\section{Federal Firm Peak Loads Under Extreme Weather Conditions OY 1995-96, 1999-2000, and 2004-05}

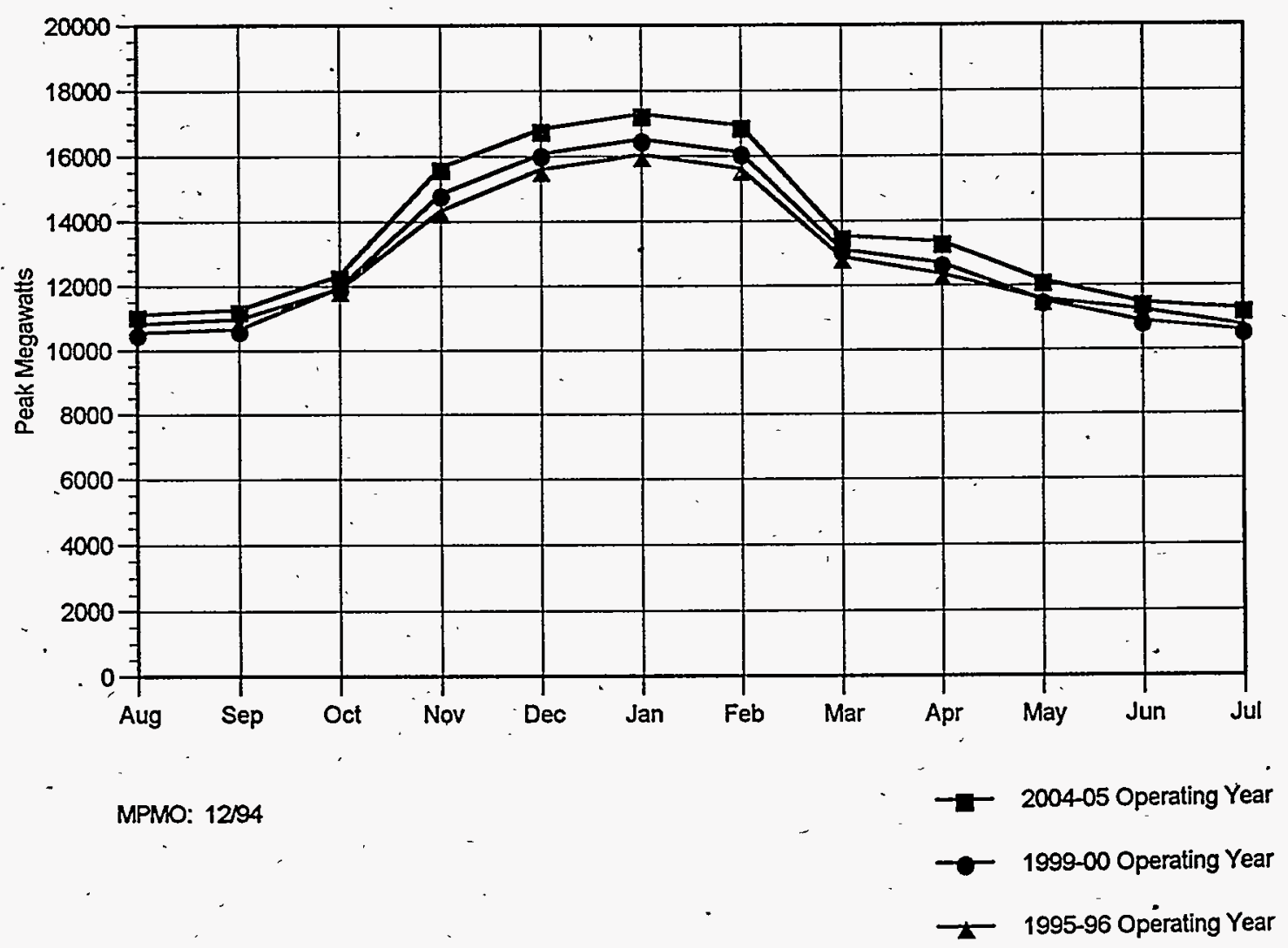


Existing Federal System Firm Resources

The Federal system hydro resources from which BPA markets power are shown in

- Table 4, page 18. In addition, BPA markets power purchased from non-Federally owned resources. BPA's. capacity/energy exchange contracts provide energy to BPA

- as payment for the capacity BPA delivers.
The non-Federally owned resources, return energy associated with BPA's existing capacity/energy exchanges, contractual resources, and other BPA hydro-related contracts are shown in Table 5, page 19.

Combined, these resources represent BPA's available firm resources. A detailed listing of all Federal generating resources is contained in the 1994 Pacific Northwest Loads and Resources Technical Appendix: Volume 1 (available Febrùary 1995). 
Table 4

Federal System Hydroelectric Projects

\begin{tabular}{|c|c|c|c|c|c|}
\hline Project & $\begin{array}{l}\text { Initial Year of } \\
\text { Service }\end{array}$ & $\begin{array}{l}\text { Number of } \\
\text { Units }\end{array}$ & $\begin{array}{l}\text { Name-plate } \\
\text { Rating } \\
\text { (MW) }\end{array}$ & $\begin{array}{l}\text { Instantaneous } \\
\text { Generating } \\
\text { Capacity } \\
\text { (peak MW) }\end{array}$ & $\begin{array}{l}\text { Firm } \\
\text { Energy } \\
\text { (aMW) }\end{array}$ \\
\hline \multicolumn{6}{|c|}{ U.S. BUREAU OF́ RECLAMATION HYDROELECTRIC PROJECTS } \\
\hline Grand Coulee & 1941 & 27 & $6,187.5$ & 6,684 & 1,875 \\
\hline Grand Coulee Pump Gen. & 1973 & 6. & 314.0 & 314. & 0 \\
\hline Hungry Horse & 1952 & 4 & 392.0 & 428 & 98 \\
\hline Palisades & 1957 & 4 & 142.2 & 164 & 61 \\
\hline Anderson Ranch & 1950 & 2 & 27.0 & 30 & 11 \\
\hline Minidoka : & 1909 & 7 & 13.4 & 16 & 9 \\
\hline Roza & 1958 & .1 & 11.3 & 13 & -4 \\
\hline Black Canyon & 1925 & 2 & 8.0 & 10 & 7 \\
\hline Chändler & 1956 & 2 & 12.0 & 13 & 7 \\
\hline \multicolumn{2}{|c|}{ TOtal U.S. BụReau of RECLAMATION Projects ${ }^{\circ}$} & 55 & $7,107.4$ & 7,672 & 2,072 \\
\hline \multicolumn{6}{|c|}{ U.S. ARMY CORPS OF ENGINEERS HYDROELECTRIC PROJECTS } \\
\hline Chief Joseph & 1955 & 27 & $2,069.0$ & 2614 & 1,156 \\
\hline John Day & 1968 & 16 & $2,160.0$ & 2484 & 911 \\
\hline The Dalles & 1957 & 22 & $1,780.0$ & 2074 & 723 \\
\hline Bonneville & 1938 & 18 & $1,050.0$ & 1186 & 477 \\
\hline McNary & 1953 & 14 & 980.0 & 1127 & 662 \\
\hline Lower Granite & 1975 & 6 & 810.0 & 932 & 217 \\
\hline Lower Monumental & 1969 & 6 & 810.0 & 930 & 218 \\
\hline Little Goose & 1970 & 6 & 810.0 & 932 & 213 \\
\hline Ice Harbor & 1961 & 6 & 603.0 & 693 & 177 \\
\hline Libby & 1975 & 5 & 525.0 & 600 & 205 \\
\hline Dworshak & 1974 & 3 & 400.0 & 460 & 164 \\
\hline Lookout Point & 1954 & 3 & 120.0 & 138 & 24 \\
\hline Detroit & 1953 & 2 & 100.0 & 115 & 34 \\
\hline Green Pefer & 1967 & 2 & 80.0 & 92 & 22 \\
\hline Lost Creek & 1975 & 2 & 49.0 & 56 & 23 \\
\hline Albeni Falls & 1955 & 3 & 42.6 & 49 & 26 \\
\hline Hills Creek & 1962 & 2 & 30.0 & 35 & 14 \\
\hline Cougar & 1964 & 2 & 25.0 & 29 & 12 \\
\hline Foster & .1968 & 2 & 20.0 & 23 & 10 \\
\hline Big Cliff & 1954 & 1 & 18.0 & 21 & 10 \\
\hline Dexter & 1955 & 1 & 15.0 & 17 & 8 \\
\hline \multicolumn{2}{|c|}{ TOTAL CORPS OF ENGINEERS PROJECTS } & 149 & $12,496.6$ & 14,607 & 5,306 \\
\hline \multicolumn{2}{|l|}{ HYDRO EFFICIENCY IMPROVEMENTS ${ }^{3}$} & $\mathbf{0}$ & $\mathbf{0}$ & $\mathbf{0}$ & 45 \\
\hline \multicolumn{2}{|l|}{ TOTAL USBR AND COE PROJECTS } & 204 & $19,604.0$ & 22,279 & 7,378 \\
\hline \multicolumn{2}{|c|}{ MAY WATER BUDGET OVERGGENERATION 4} & $\mathbf{0}$ & $\mathbf{0}$ & $\mathbf{0}$ & -216 \\
\hline \multicolumn{2}{|c|}{$\begin{array}{l}\text { JUNE COLUMBIA RIVER FLOW AUGMENTATION } \\
\text { OVERGENERATION }^{4}\end{array}$} & $\mathbf{0}$ & $\mathbf{0}$ & 0 & -162 \\
\hline \multicolumn{2}{|l|}{ TOTAL USBR AND COE PROJECTS } & 204 & $19,604.0$ & 22,279 & 7,000 \\
\hline
\end{tabular}

${ }^{1}$ Maximum generation under optimum conditions. Does not reflect reduction to the peaking capacity of the hydro system due to the drafting of reservoirs and other project constraints.

${ }^{2}$ Firm energy from a 42-month critical period.

${ }^{3}$ Contracted hydro efficiency improvements are being completed on various hydroelectric projects. These efficiency improvements were not included in this year's hydro regulation.

${ }^{4}$ May Water Budget and June Columbia River Flow Augmentation reductions are due to excessive generation in the months of May and June during the 42-month critical period in support of fish mitigation. 
Table 5

\section{Non-Federally Owned BPA Resources and Contracts Capacity based on January 1996}

\begin{tabular}{|c|c|c|c|c|c|}
\hline Project & Type & Operator & $\begin{array}{l}\text { Date in } \\
\text { Service }\end{array}$ & $\begin{array}{l}\text { DY 1995-96 } \\
\text { Capacity } \\
\text { (peak MW) }\end{array}$ & $\begin{array}{c}\text { OY 1995-96 } \\
\text { Firm Energy } \\
\text { (aMW) }\end{array}$ \\
\hline \multicolumn{6}{|c|}{ Existing Non-Federally Owned BPA Resources } \\
\hline WNP-2 & Nuclear & WPPSS & 1984 & $1,170^{1}$ & $819^{1}$ \\
\hline Packwood Lake & Hydro & WPPSS & 1964 & 30 & 8 \\
\hline Idaho Falls & Hydro & $\begin{array}{l}\text { City of Idaho } \\
\text { Falls }\end{array}$ & 1982 & 18 & 18 \\
\hline Cowlitz Falls & Hydro & $\begin{array}{l}\text { Lewis County } \\
\text { PUD }\end{array}$ & 1994 & $25^{2}$ & 22 \\
\hline $\begin{array}{l}\text { McNary Fishway } \\
\text { Hydro Unit }\end{array}$ & Hydro & $\begin{array}{l}\text { Northern } \\
\text { Wasco PUD }\end{array}$ & 1997 & $0^{3}$ & $0^{3}$ \\
\hline Big Creek Hydro Unit & Hydro & $\begin{array}{l}\text { Mission } \\
\text { Valley } \\
\end{array}$ & 1981 & 1 & 0 \\
\hline \multicolumn{4}{|c|}{ TOTAL NON-FEDERALLY OWNED BPA RESOURCES } & 1,244 & 867 \\
\hline \multicolumn{6}{|l|}{ Firm Contracts } \\
\hline \multicolumn{4}{|l|}{ Canadian Entitlement } & 162 & 58 \\
\hline \multicolumn{4}{|c|}{ Restoration, Columbia River Treaty w/Canada } & 0 & -26 \\
\hline \multicolumn{4}{|c|}{ Southwest Capacity/Energy Exchanges } & $\mathbf{0}$ & 10 \\
\hline \multicolumn{4}{|c|}{ Montana Power Capacity/Energy Exchange } & 0 & 29 \\
\hline \multicolumn{4}{|c|}{ PacifiCorp (Wyoming) Import for Southern Idaho Load } & 189 & 94 \\
\hline \multicolumn{4}{|c|}{ Basin Electric Cooperative Purchase ${ }^{4}$} & 120. & 85 \\
\hline \multicolumn{4}{|c|}{ WNP-3 Exchange Settlement Agreements } & $\mathbf{0}$ & 113 \\
\hline \multicolumn{4}{|c|}{ Montana Power Purchase 5} & 75 & 53 \\
\hline \multicolumn{4}{|c|}{ Puget Sound Power \& Light Purchase ${ }^{6}$} & 0 & 29 \\
\hline \multicolumn{4}{|c|}{ San Diego Gas \& Electric, Capacity/Energy Exchange ${ }^{7}$} & $\mathbf{0}$ & 22 \\
\hline \multicolumn{4}{|c|}{ San Diego Gas \& Electric, Deferred Return Energy ${ }^{T}$} & 0 & 51 \\
\hline \multicolumn{4}{|c|}{ Southern California Edison Environmental Storage ${ }^{8}$} & 0 & 7 \\
\hline \multicolumn{4}{|c|}{ TOTAL BPA FIRM CONTRACTED RESOURCES } & 546 & $\mathbf{5 2 7}$ \\
\hline \multicolumn{4}{|c|}{ TOTAL NON-FEDERALLY OWNED BPA RESOURCE CONTRACTS } & 1,790 & 1,394 \\
\hline
\end{tabular}

\footnotetext{
${ }^{1}$ Efficiency improvements will increase WNP-2 capacity to 1,170 megawatts and energy capability to 878 average megawatts when completed in OY 2001.

${ }^{2}$ Operational capacity is 70 megawatts, but is restricted in January.

3 Operational date is July 1,1997 . Peak capability. will be 8 megawatts and 7 average megawatts of annual energy.

${ }^{4}$ The Basin Electric Cooperative contract began November, 1991, and ends April 23, 1999.

5 The Montana Power Company contract began July 1, 1993, and ends June 30, 1996.

6 The Puget Sound Power \& Light contract began July 1, 1993, and ends June 30, 1996.

7 The San Diego Gas \& Electric contract begins August 1, 1993, and ends July 31, 1997.

8 The Southern California Edison contract begins April 16, 1995, and ends February 29, 2005.
} 
Table 6 summarizes the Federal system firm energy resources and contracts available to meet Federal firm loads for OY 1995-96. Federal system firm energy resources are comprised as follows: 83 percent from hydroelectric power, 10 percent from one nuclear power plant, and 7 percent from BPA's firm contracts.

\section{Table 6}

Federal System1 Firm Resources for OY 1995-96² Capacity based on January 1996

\begin{tabular}{|l|c|c|c|c|}
\hline & $\begin{array}{c}\text { Sustained } \\
\text { Peak Capacity } \\
\text { (MW) }\end{array}$ & $\begin{array}{c}\text { Generating } \\
\text { Peaking } \\
\text { Capacity } \\
\text { \% of Total }\end{array}$ & $\begin{array}{c}\text { Firm } \\
\text { Energy } \\
\text { (aMW) }\end{array}$ & $\begin{array}{c}\text { Firm. } \\
\text { Energy } \\
\% \text { of Total }\end{array}$ \\
\hline Hydro & 15,008 & 91 & 7,122 & 83 \\
\hline Nuclear & 1,170 & 7 & 819 & 10 \\
\hline Firm Contracts & 375 & 2 & 573 & 7 \\
\hline \hline TOTAL FEDERAL ResourCES & $\mathbf{1 6 , 5 5 4}$ & $\mathbf{1 0 0}$ & $\mathbf{8 , 5 1 9}$ & 100 \\
\hline
\end{tabular}

${ }^{1}$ Includes Federally and non-Federally owned projects.

2 Operating Year (OY) is the 12-month period August 1 through July 31. For example, OY 1995-96 is August' 1, 1995, through July 31, 1996.

\section{Federal System Nonfirm Resources}

BPA planning does not include nonfirm energy in its Federal system loads and resources balance; however, it is an important component of BPA's marketing programs and revenue forecasts. Regional nonfirm energy can vary from zero in the worst water conditions to as much as 8,300 average megawatts in the best water year. Federal system nonfirm energy comprises approximately 60 percent of the region's nonfirm energy. Federal nonfirm energy averaged over 50 years of historical water flows would increase the Federal. system resources from 2,300 to 2,600 average megawatts.

The NMFS Draft Biological Opinion dated March 16, 1994, was incorporated in this year's 50-year nonfirm energy analysis. This changes the shape and availability of nonfirm energy.

\section{Federal System Firm Energy . Surpluses/Deficits}

This analysis includes all operating requirements currently adopted by the hydroelectric project owners and the firm planning assumptions from the NMFS Draft Biological Opinion dated March 16, 1994.

The Federal firm energy surpluses/deficits under the various load forecasts for OY 1995-96 through 2004-05 are presented in Table 7, page 21 , and graphically shown in Figure 3, page 22. The Federal system is energy deficit throughout the 10-year study period under the medium load forecast. Although utility loads continue to grow through the 1990 s, the 
Federal system deficit, under medium loads, does not increase significantly due to the expiration of the WNP-1 exchange contract obligation on June 30,1996 , returning 340 average megawatts of firm energy to the Federal system.

The components of the 10-year critical period average Federal energy loads and resources balances under the medium load scenario is presented in Exhibit 1, line 45, page 44.
To show the monthly variability of the loads and resources study, the monthly Federal system energy components assuming medium loads under 1930 water conditions for OY 1995-96, 1999-2000, and 2004-05 are shown in Exhibits 2 through 4, pages 48 through 53 .

Figure 4, page 22, shows the impact of the May Water Eudget and June CRFA on the Federal system energy surpluses/deficits.

\section{Table 7 \\ Federal System Firm Energy Surpluses/Deficits Assuming Existing Loads, Resources, arid Contracts Energy In Average Megawatts}

\begin{tabular}{|c|c|c|c|c|c|c|c|c|c|c|}
\hline & \multicolumn{10}{|c|}{ OPERATING YEAI? } \\
\cline { 2 - 11 } & 1996 & 1997 & 1998 & 1999 & 2000 & 2001 & 2002 & 2003 & 2004 & 2005 \\
\hline Medium Load Scenario & -210 & -12 & -22 & -114 & -301 & -303 & -309 & -422 & -590 & -699 \\
\hline
\end{tabular}

1 Operating Year (OY) is the 12-month period August 1 through July 31. For example, OY 1995-96 is August 1, 1995, through July 31, 1996. 
Figure 3

Federal Firm Energy Surpluses/Deficits

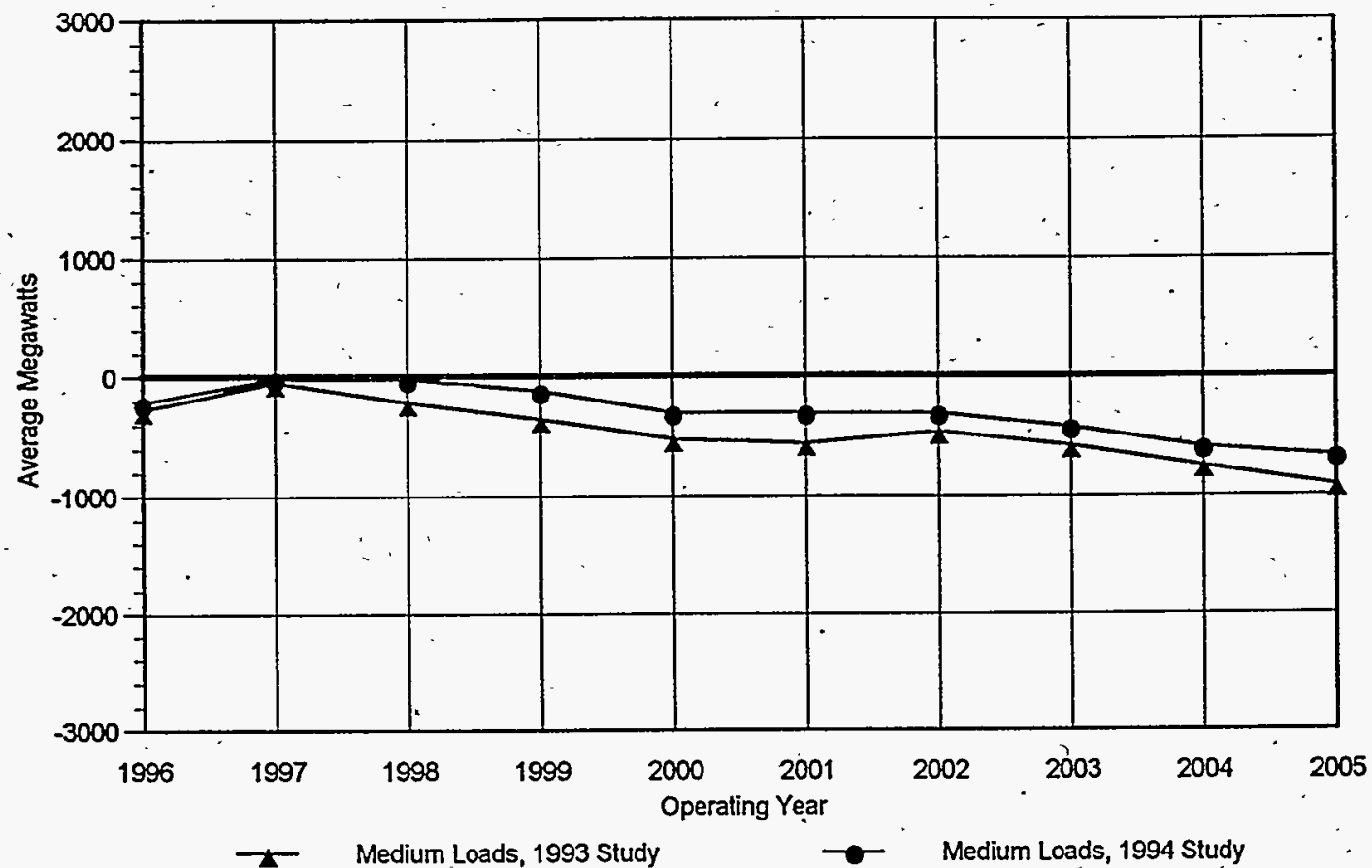

Figure 4

Effect of May Water Budget and June Columbia River Flow Augmentation on the Federal Firm Energy Surplus Medium Load Forecast

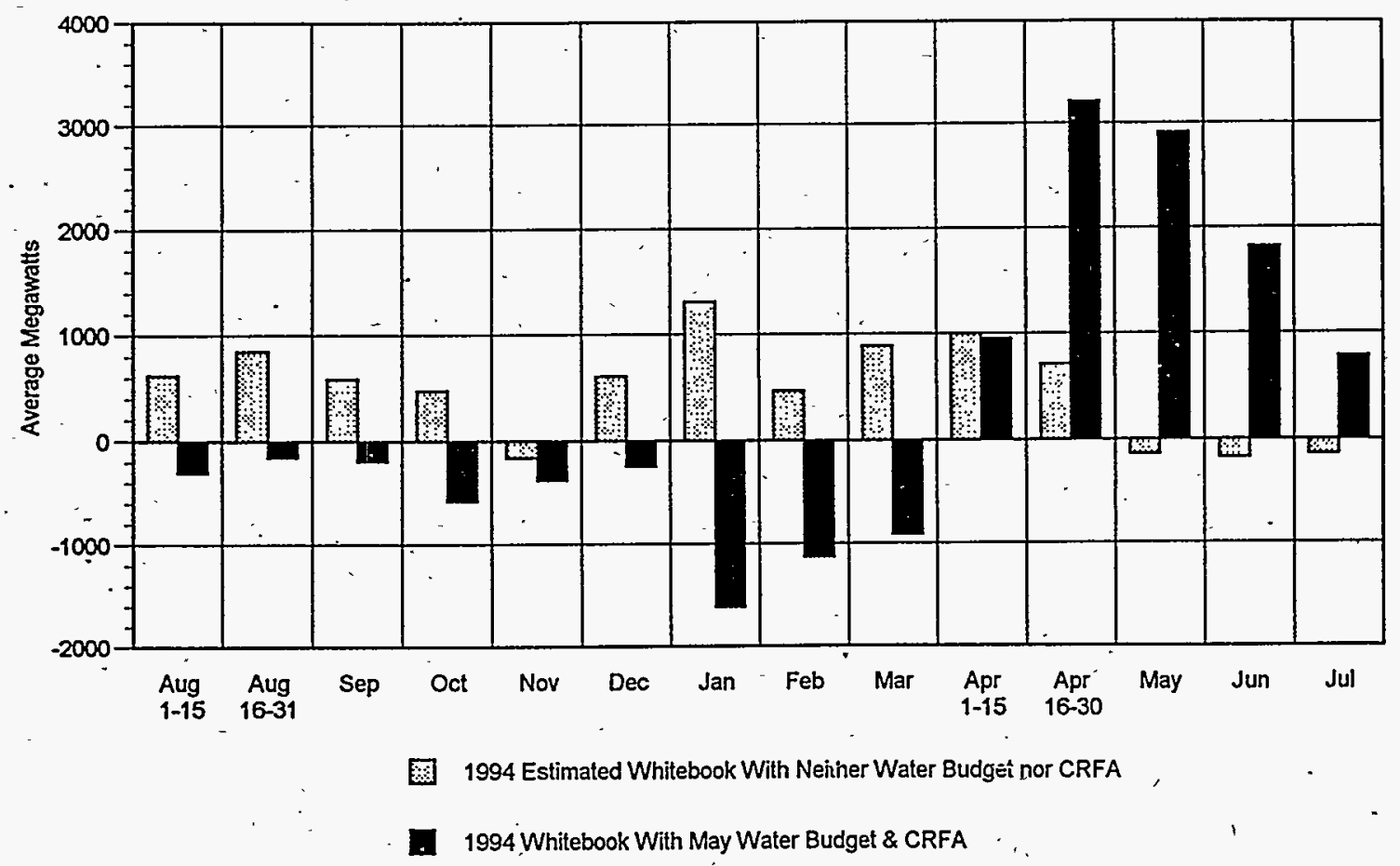




\section{PLANNING TO MEET FORECASTIED DEFICITS}

As part of its Competitiveness Project, BPA has developed marketing and business plans that may alter the way the agency acquires and markets resources. Therefore, only existing contractual resource options now available to BPA are included in this section of the study.

\section{Contractual Resource Options}

BPA has long-term surplus firm power sale and capacity/energy exchange contracts with five Southwest utilities: Southern California Edison (SCE); the M-S-R Public Power Agency (M-S-R), whose members include the Modesto Irrigation District, and the cities of Santa Clara and Redding, California; and the cities of Burbank, Glendale, and Pasadena, California.

BPA also has a long-term surplus firm power sale and seasonal exchange contract with one Northwest utility-Puget Sound Power and Light.

The above contracts contain provisions, throughout their duration, for complete or partial termination of energy deliveries if that energy is needed to serve BPA's firm requirements.

The Southwest utilities contracts allow BPA to terminate surplus firm energy deliveries and convert these contracts to capacity/energy exchange contracts under the following conditions:

- On an annual basis, following a determination by BPA under annual
Pacific Northwest Coordination Agreement planning; or

- On 60-days' notice pursuant to Public Law 88-55:?.

These provisions relieve BPA of its energy delivery obligations and make those resources available to BPA for meeting firm energy requirements. Energy may be acquired from the following categories:

- Energy made available from the termination of energy deliveries under Southwest surplus firm energy sales;

- Exchange energy available upon conversion of the Southwest surplus firm energy sales to capacity/energy exchanges; and

- Supplemental energy available to BPA for purchase upon conversion of the Southwest surplus firm energy sales to capacity/energy exchanges.

In the event that BPA terminates energy deliveries of these. Southwest surplus sales and converts them to exchanges, provisions within the contracts, except the city of Burbank's, allow for later reversion back to surplus energy sales, depending on the availability of Federal surplus firm energy and certain other conditions.

This study assumes that these contracts retain their power sale status throughout their terms (expiration dates range from OY 2007-08 to 2012-13). Should BPA terminate these sales and convert them to capacity/energy exchanges, exchange energy would become available to BPA as a firm resource. The additional resources resulting from early conversion of these sur- 
plus firm power sales to capacity/energy exchanges are shown in Table 8, lines 1 and 2 , page 25 .

Supplemental Energy: If BPA terminates Southwest sales and converts them to capacity/energy exchange contracts, BPA may elect to purchase supplemental energy in that same operating year. The amount of additional resources that would become available upon early conversion of these contracts and purchase of supplemental energy is shown in Table 8, line 3 .

Option Energy: BPA also has contractual rights to purchase optional energy from Southern California Edison. This contract allows BPA to purchase up to 71 average megawatts of optional energy on a rolling 5-year basis starting in OY 1994-95. In addition, BPA has nearterm contractual rights to purchase optional energy from San Diego Gas and Electric Company. This contract allows BPA to purchase up to 4.5 average megawatts of option energy during OY 1994-95 through OY 1996-97. BPA considers these contracts as resource options, which BPA may elect to purchase; they are not considered firm resources in this study. BPA included Southern California Edison option energy as a firm resource in the 1993-94 Pacific Northwest Coordination Agreement operating plan. The total optional energy available to BPA under these contracts is shown in Table 8, line 4.

Pacific Northwest Surplus Firm Energy: In addition, BPA has a surplus firm sale and seasonal power exchange agreement with Puget Sound Power and Light. This contract contains provisions that allow BPA to terminate the surplus energy sale on the earlier of:

- 5-years' written notice from BPA; or

- on July 1, 2001.
In this event, the surplus energy sale converts to a seasonal power-for-power exchange. BPA's right to issue 5-years' written notice is in accordance with Section 5(a) of the Bonneville Project Act; (Public Law 75-329, as amended), and Section 5(f) of the Northwest Power Act (Public Law 96-501). This study assumes that this surplus sale will extend through OY 2000-01, when the contract is required to be converted to seasonal exchange status. If BPA needs the energy earlier, the contract will be terminated as a power sale and convert to a seasonal power exchange in that year and for the remainder of the contract. The earliest that BPA can terminate surplus firm energy deliveries to Puget Sound Power and Light Company is OY 2000-01. The amount of resources available to BPA, under all load forecasts, from the conversion of this contract to a seasonal power exchange is shown in Table 8 , line 5 .

\section{Non-Treaty Storage}

On July 9, 1990, BC Hydro and BPA signed an agreement increasing United States-Canadian coordination of the Columbia River system. This agreement cooperatively manages 4.5 million acre-feet of non-treaty hydro storage through June 30, 2003. Studies on the increased coordination indicate a possible increase of 300 average megawatts in firm energy for the combined Canadian and Pacific Northwest systems. Fifty percent of the beriefit, 150 average megawatts, is available to the United States. The Federal system share is 115 average megawatts. This energy, however, is not as valuable as a firm resource because non-treaty storage has a lower refill priority than primary storage reservoirs. Therefore, BPA intends to use the non-treaty storage as a resource option 
to increase flexibility in operating the hydro system. Since this energy may not be available every year, it is not included as a firm resource in this loads and resources study.
However, it may be included as a firm resource in future studies. Non-treaty storage is included in Table 8 , line 6.

Table 8

\section{Existing Federal System Contractual Resource Options Energy In Average Megawatts}

\begin{tabular}{|l|r|r|r|r|r|r|r|r|r|r|}
\hline OPERATING YEAR ${ }^{1}$ & 1996 & 1997 & 1998 & 1999 & 2000 & 2001 & 2002 & 2003 & 2004 & 2005 \\
\hline $\begin{array}{l}\text { 1. Termination of PSW } \\
\text { Surplus Power Sales }\end{array}$ & 212 & 237 & 237 & 237 & 237 & 237 & 237 & 237 & 237 & 237 \\
\hline $\begin{array}{l}\text { 2. Exchange Energy } \\
\text { From PSW }\end{array}$ & 68 & 71 & 74 & 73 & 71 & 70 & 69 & 68 & 67 & 66 \\
\hline $\begin{array}{l}\text { 3. Supplemental Energy } \\
\text { From PSW }\end{array}$ & 37 & 38 & 39 & 41 & 42 & 43 & 44 & 46 & 47 & 48 \\
\hline $\begin{array}{l}\text { 4. Optional Energy From } \\
\text { PSW }\end{array}$ & 76 & 76 & 71 & 71 & 71 & 0 & 0 & 0 & 0 & 0 \\
\hline $\begin{array}{l}\text { 5. Termination of PNW } \\
\text { Surplus Power Sale }\end{array}$ & 0 & 0 & 0 & 0 & 0 & 75 & 0 & 0 & 0 & 0 \\
\hline 6. Non-Treaty Storage & 115 & 115 & 115 & 115 & 115 & 115 & 115 & 115 & -0 & 0 \\
\hline TotaL ConTRACTUAL Options & 508 & 537 & 536 & 537 & 536 & 540 & 465 & 466 & 351 & 351 \\
\hline
\end{tabular}

${ }^{1}$ Operating Year (OY) is the 12-month period August 1 through July 31. For example, OY 1995-96 is August 1, 1995, through July 31, 1996. 
Federal System Firm Capacity Surpluses/Deficits

Figure 5 shows the Federal firm capacity surpluses/deficits under the medium load forecast for OY 1995-96, 1999-2000, and 2004-05. This analysis incorporates all operating requirements currently adopted by the hydroelectric project owners and the firm planning assumptions from the NMFS Draft Biological Opinion dated March 16, 1994.

The monthly capacity surpluses/deficits incorporate the Federal System assumptions noted on page 13 .

\section{Figure 5}

\section{5-96 Federal Fịrm Capacity Surpluses/Deficits Under Extreme Weather Conditions'}

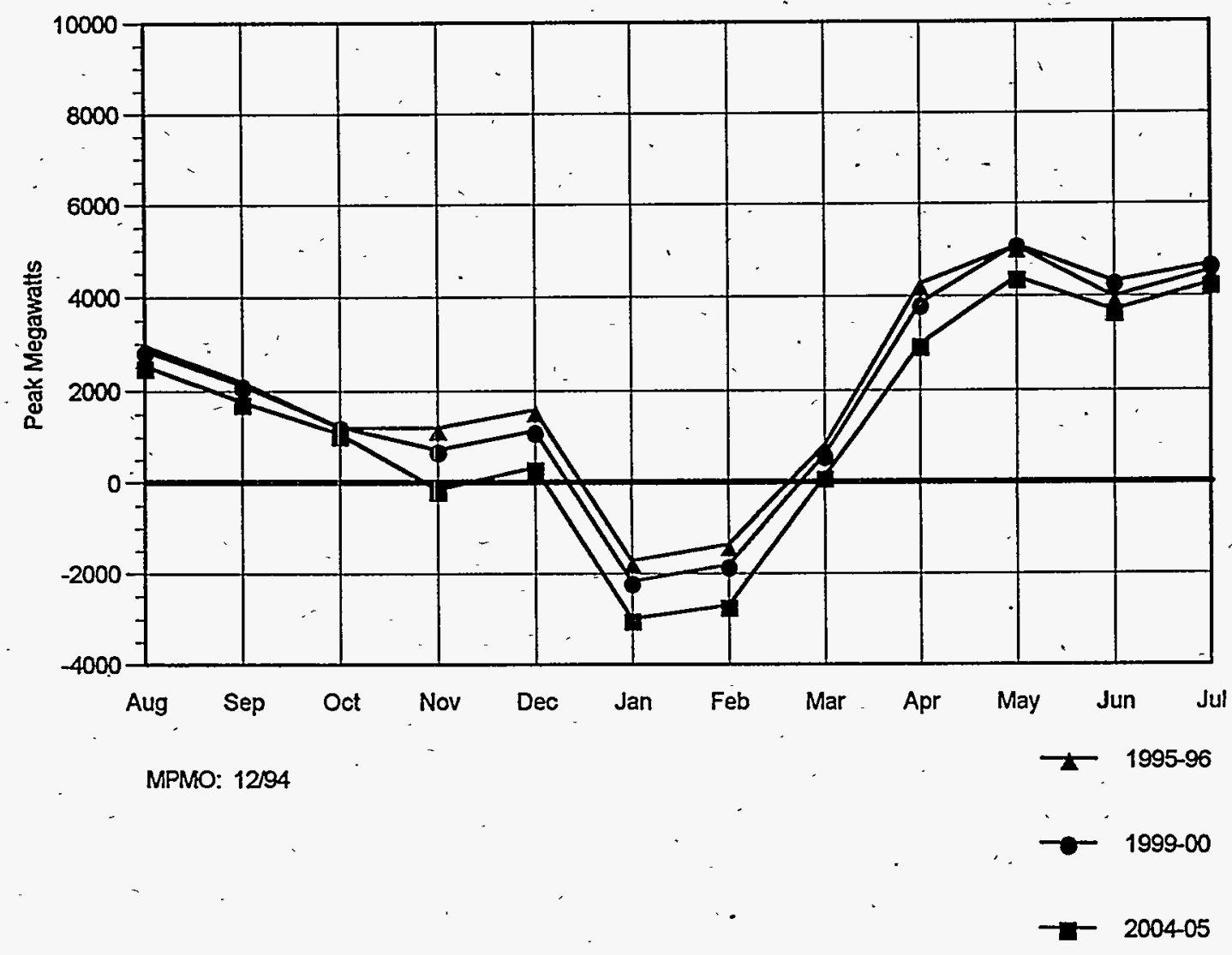

${ }^{1}$ Extreme weather conditions in the months of November, December, January, and February assume a

5-percent probability that the peak load will be exceeded. 
The study assumes that there are no nighttime return problems from future capacity sales. Nighttime return problems can occur when replacement energy from capacity sales, combined with minimum hydro generation, the output from other Federal resources, and other Federal contract returns are greater than BPA's nighttime load. The following factors contribute to nighttime return problems:

- Low Federal system loads;

- Additional nonpower hydro requirements that dictate minimum streamflows; and

- The inability of BPA's WNP-2 nuclear resource to cycle from day to night.

These requirements restrict the ability to accept nighttime return energy, even though there is surplus generating capability during the daytime. These constraints are common in summer and fall, when BPA's nighttime loads are low. BPA's future Federal surplus capacity transactions. may include provisions to:

- Limit return energy to a percentage of contract demand;

- Defer energy returns to a time more favorable to system operations; or

- Request cash payment in lieu of return energy.

BPA's surplus firm capacity values take into account the following Federal system - hydro constraints:

- Limitations on moving water between projects, including upstream storage;

- Pondage limitations due to hydraulic imbalance from reservoir to reservoir; and

- Navigation and recreation ..constraints, including restrictions on the rate of rise or fall of tailwater and forebay elevations.
As BPA acquires future resources, the added capacity will increase capacity available to the Federal System.

A 10-year summary of Federal capacity surpluses/deficits under the medium load forecast, assuming extreme weather conditions, is presented in Exhibit 5, page 56. The monthly variability of the Federal system capacity components that comprise the loads and resources study assuming medium loads for extreme weather under 1930 water conditions for OY 1995-96, 1999-2000, and 2004-05 are shown on line 51 in Exhibits 6 through 8 , pages 58 through 65 .

\section{Federal System Loads and Resources Comparison-Energy}

Table 9, page 29, shows changes in the energy analysis of the 1994 Pacific Northwest Loads and Resources Study compared to the 1993 Pacific Northwest Loads and Resources Study for OY 1995-96 through 2003-04. The table lists the Federal firm energy surpluses/deficits for the 1993 study and changes since last year to obtain the current firm energy surplus under the medium load forecast. Positive values in the table indicate an increase and negative values indicate a decrease in Federal system firm energy surpluses. Federal planned resource acquisitions are not included as firm resources because they have not yet been contracted for. Similarly, resource options that BPA already has contractual rights to acquire, if needed, have not been included because BPA may or may not exercise the options in any given year.

Changes were based on the following updates in loads, contracts, and resources:

\section{Federal Agencies and USBR}

Federal agencies' loads were decreased by 10 average megawatts for the study period. 


\section{DSi Aluminum Firm Loads}

The near-term portion of the 1994 BPA forecast assumes that DSI aluminum smelter firm load will be 1,916 average megawatts in OY 1996 are forecasted to remain constant over the study period. In the 1993 study, DSI aluminum smelter firm loads were forecasted to decline over the study period, thus decreasing the DSI aluminum loads.

\section{DSI Non-Aluminum Firm Loads}

There are few differences in the nonaluminum DSI loads from this year's analysis compared to the 1993 study.

\section{Non-Generating Public Agencies' Power Sales Contract Purchases}

This year's study shows decreased sales to small and non-generating public agencies due to load reductions included for competitive acquisitions, tiered rates, conservation responses, market transformation, power plants, and other codes and stàndards (not MCS) of up to 82 average megawatts over the study period. In addition, this study contains new small generating public resources including Clark County PU'D's Cogentrix (202 average megawatts) and Grays Harbor PUD's share of Centralia (50 average megawatts); which reduced the non-generating public agencies' purchases from BPA.

\section{Generating Public Agencies' Power Sales Contract Purchases}

Sales to the generating public agencies decreased due to load reductions included for competitive acquisitions, tiered rates, conservation responses, market transformation, power plants, and other non-MCS codes and standards. The generating public agencies" share of these load reductions totals up to 102 average megawatts over the study period.

\section{Exports}

BPA's new diversity exchange with Riverside, capacity/energy exchange with Pasadena, and environmental exchange with Southern California Edison represent the monthly load increases on BPA associated with these deliveries.

\section{Contracts Out}

The 1994 study includes a new contract with Washington Water Power for deferred power deliveries extending through June 30, 2000.

\section{Regulated Hydro}

The NMFS Draft Biological Opinion dated March 16, 1994, was used for the hydro regulation study. In addition, the inclusion of the May Water Budget and June CRFA significantly reduces the Federal system hydro generation.

\section{Imports}

To cover potential short-term firm energy deficits, BPA extended its purchase. from Basin Electric Cooperative through April 31, 1999.

In addition, BPA's new contracts include deferred replacement energy returns from San Diego Gas and Electric, diversity exchange from Riverside, exchange energy from Pasadena, and environmental exchange with Southern California Edison.

\section{Contracts In}

To cover potential short-term deficits, BPA purchased power from Puget Sound Power and Light and Montana Power through OY 1996-97. BPA also revised its WNP-1 contract with Washington Water Power for deferred returns considerations through June 30, 2000. 


\section{WNP-2}

WNP-2 turbine and efficiency improvements increased the nuclear plant's output by up to 127 average megawatts over last year's study.

\section{Non-Utility Generation}

Federal non-utility generation includes Tenaska II (Frederickson), SOS Lumber,
Clearwater, and Wyoming Wind, bringing up to 184 average megawatts of generation to the Federal system.

\section{Miscellaneous Changes}

The miscellaneous changes in this year's study include revised USBR loads, new Canadian Entitlement obligations beginning April 1, 1998, and revised transmission losses.

\section{Table 9}

\section{Changes in Federal System Firm Energy Siurplus/Deficit Medium Load Forecast}

Energy in Average Megawatts

\begin{tabular}{|c|c|c|c|c|c|c|c|c|c|}
\hline Operating Year ${ }^{1}$ & 1996 & 1997 & 1998 & 1999 & 2000 & 2001 & 2002 & 2003 & 2004 \\
\hline 1993 Federal Firm Energy Surplus Deficit $^{2}$ & -270 & 43 & -212 & -352 & -518 & -559 & -464 & -579 & -748 \\
\hline \multicolumn{10}{|c|}{ Load Changes: (+ Load Increase, - Load Decrease) } \\
\hline Federal Agencies \& USBR & -9 & -10 & -9 & -9 & -10 & -9 & -10 & -9 & -9 \\
\hline DSI Aluminum Firm Loads & -66 & 126 & 130 & 133 & 142 & 163 & 279 & 290 & 301 \\
\hline DSI Non-Aluminum Firm Loads & -11 & -1 & 2 & 2 & 2 & 1 & -1 & -2 & -2 \\
\hline Small Public Agency Purchases & -67 & -91 & -291 & -345 & -346 & -341 & -337 & -330 & -318 \\
\hline $\begin{array}{l}\text { Generating Public Agency } \\
\text { Purchases }\end{array}$ & 0 & -65 & -76 . & -91 & -91 & -91 & -98 & -85 & -85 \\
\hline Fed \& Generating Public Losses & -10 & 0 & -1 & 0 & 1 & 2 & 5 & 5 & 5 \\
\hline IOU Purchases & 0 & 0 & 0 & 0 & 0 & 0 & 0 & 0 & 0 \\
\hline Exports & 9 & 13 & 15 & 15 & 15 & 15 & 14 & 15 & 13 \\
\hline Contracts Out & 5 & 22 & 27 & 28 . & 25 & -1 & 0 & 0 & 0 \\
\hline Total Load Changes & -149 & -6 & -203 & -267 & -262 & -261 & -148 & -116 & -95 \\
\hline \multicolumn{10}{|c|}{ Resource Changes: (+ Resource Increase, - Resource Decrease) } \\
\hline Regulated Hydro & -217 & -217 & -217 & -240 & -240 & -240 & -240 & -240 & -240 \\
\hline Independent Hydro & -1 &.-1 & 0 & $\mathbf{0}$ & 0 & 0 & 0 & 0 & 0 \\
\hline May Water Budget & 49 & 38 & 30 & 44 & 49 & 53 & 59 & 74 & 82 \\
\hline June Columbia River Flow Aug. & -162 & -180 & -190 & -178 & -171 & -169 & -162 & -146 & -138 \\
\hline Imports & 86 & 81 & 81 & 60 & 22 & 22 & 22 & 22 & 22 \\
\hline Contracts In & 78 & 59 & 7 & 6 & 7 & 7 & 7 & 7 & 7 \\
\hline WNP-2 & 72 & 70 & 91 & 91 & 94 & 127 & 127 & 127 & 127 \\
\hline Non-Utility Generation & 6 & 175 & 183 & 183 & 183 & 183 & 183 & 183 & 183 \\
\hline Miscellaneous & 0 & 0 & 2 & 5 & 11 & 12 & 11 & 14 & 20 \\
\hline Total Resource Changes & -89 & 25 & -13 & -29 & 45 & -5 & 7 & 41 & $\overline{63}$ \\
\hline $\begin{array}{l}\text { Difference: } 1993 \text { Study Less } 1994 \text { Study } \\
\text { Resource Changes - Load Changes }\end{array}$ & 60 & 31 & 190 & 238 & 217 & 256 & 155 & 157 & 158 \\
\hline $\begin{array}{l}1994 \text { Federal System Firm Energy } \\
\text { Surplus/Deficit }{ }^{3}\end{array}$ & -210 & -12 & -22 & -114 & -301 & -303 & -309 & -422 & -590 \\
\hline
\end{tabular}

${ }^{1}$ Operating Year (OY) is the 12-month period August 1 through July 31. For example, OY 1995-96 is August 1, 1995, through July 31, 1996.

21993 Pacific Northwest Loads and Resources Study, December 1993, page 42.

3 1994 Pacific Northwest Loads and Resources Study, December 1994, page 21. 
Federal System Loads and Resources Comparison-Capacity

Table 10 , page 32 , shows changes in the capacity analysis of the 1994 Pacific Northwest Loads and Resources Study compared to the 1993 Pacific Northwest Loads and Resources Study for OY 1995-96. The table lists the Federal system firm 50-hoursper-week capacity surpluses/deficits for the 1993 study and changes since last year to obtain the current firm 50-hours-per-week capacity surplus under the medium load forecast. Positive values in the table indicate an increase and negative values indicate a decrease in the Federal system firm capacity surpluses. As previously discussed, Federal planned resource acquisitions not yet contracted for and contracted for resource options are not included as firm resources.

Changes were based on the following updates in loads, contracts, and resources:

\section{DSI Firm Loads}

The DSI near-term forecast shows capacity loads decreasing by as much as 142 peak megawatts in August of OY 1996 versus the 1993 study. This is due to lower aluminum prices, and drought conditions in: the region.

\section{Non-Generating Public Agencies' Power Sales Contract Purchases}

This year's study shows generally decreased sales to small and non-generating public agencies due to additional conservation load reductions, increases, Grays Harbor PUD's dedication of their share of Centralia, and Clark County PUD's Cogentrix plant, with loads decreasing as much as 182 peak megawatts in December of OY 1995-96.

\section{Generating Public Agencies' Power Sales Contract Purchases}

Sales to the generating public agencies under their power sales contracts decrease by up to 140 peak megawatts in February of OY 1995-96. This change is due to decreases in the generating public agencies peak load forecast due to additional load reductions of up to 102 peak megawatts and increases in the amount of resources dedicated by the generating public agencies to serve their own loads.

\section{Investor-Owned Utilities' Power Sales Contract Purchases}

Since last year's study, Portland General Electric revised its 150-megawatt capacity purchase from BPA: PGE now is purchasing this capacity under a surplus peak contract with BPA included in Contracts In.

\section{Exports}

Since last year's analysis, BPA has completed a capacity/energy exchange with Pasadena, a diversity exchange with Riverside, and an environmental exchange with Southern . California Edison, which decreased the available Federal capacity surplus during May through September.

\section{Contracts Out}

This year's study includes BPA's 1,100 peak megawatt capacity sale with PacifiCorp and 150 peak megawatt capacity sale with Portland General Electric.

\section{Federal System Diversity}

Decreases in the obligation of the Federal system to the public agencies and IOUs under their power sales contracts and new Federal contracts decreased Federal system diversity impacts. 


\section{Extreme Weather Adjustments}

The extreme weather adjustments changed slightly compared to the 1993 study mainly due to decreases in BPA's obligation to public agencies under their power sales contracts.

\section{Regulated Hydro}

As previously discussed, the 1994 hydro regulation study included CRFA. These changes included storing water in reservoirs in the winter for later release in the late spring and early summer. This created lower flows in the winter and additional flows, especially in the late spring and summer, thus reducing the available hydro in the winter and increased the hydro capability in the spring and early summer when compared to last year's study.

\section{Sustained Peaking Adjustment}

The 50-hours-per-week sustained peaking adjustment in this year's analysis decreased the regional capacity surplus in the hydro regulation versus the 1993 study. This is due to changes in the shaping of the hydro system due to CRFA. By storing in the months of January through April 15, the availability of sustained peaking diminished dramatically in some months.

\section{Imports}

To cover potential short-term firm energy deficits, BPA extended its purchase from Basin Electric Cooperative through April 31, 1999, which increased capacity resources.

\section{WNP-2}

The change in generation is due to efficiency improvement at the project.

\section{Hydro Reserves/Large Thermal Reserves/Spinning Reserves}

The change in reserves is due to variations in hydro and thermal capabilities.

\section{DSI Reserves}

The DSI system operating reserve is estimated at one-third the DSI firm load, limited by the amount of Federal thermal forced outage reserve.

\section{Contracts in}

BPA revised its WNP-1 obligation contract with Washington Water Power for deferred power deliveries to cover shortterm firm energy deficits.

\section{Miscellaneous Changes}

The miscellaneous changes in this year's study include revised USBR agency loads, and revised transmission losses. 


\section{Table 10}

Changes in Federal System 50-Hours-Per-Week Firm Capacity Surplus/Deficit For Operating Year 1995-961

Medium Load Forecast - Peak in Megawatts

\begin{tabular}{|c|c|c|c|c|c|c|c|c|c|c|c|c|c|c|}
\hline Operating Year 1995-96 & $\begin{array}{l}\text { Aug } \\
1-15\end{array}$ & $\begin{array}{c}\text { Aug } \\
16-31\end{array}$ & Sep & Oct & Nov & Dec & Jan & Feb & Mar & $\begin{array}{l}\text { Apr } \\
1-16 \\
\end{array}$ & $\begin{array}{c}\text { Apr } \\
16-30\end{array}$ & May & Jun & July \\
\hline 1993 Federal Firm Energy Surplus/Deficit ${ }^{2}$ & 4,782 & 5,188 & 3,535 & 3,470 & 3,162 & 3,029 & 3,563 & 2,583 & 5,095 & 4,673 & $.3,821$ & 5,421 & 2,681 & 3,091 \\
\hline \multicolumn{15}{|c|}{ Load Changes: (+ Load Increase, - Load Decrease) } \\
\hline Federal Agencies \& USBR & -11 & -11 & -11 & -12 & -8 & -8 &.-8 & -8 & -7 & -11 & -11 & -12 & -11 & -11 \\
\hline DSI Aluminum Firm Loads & -142 & -142 & -142 & -101 & -101 & -101 & -62 & -56 & -57 & -55 & -55 & -55 & -56 & 127 \\
\hline DSI Non-Aluminum Firm Loads & -27 & -27 & -27 & -23 & -6 & -6 & -14 & -6 & -6 & -6 & -6 & -6 & -10 & -10 \\
\hline Non-Generating Public PSC Purchases & -139 & -139 & -147 & -117 & -126 & -182 & -175 & 22 & -105 & 8 & 8. & -127 & 3 & -56 \\
\hline Generating Public PSC Purchases & -22 & -16 & -15 & -6 & -21 &,-52 & -140 & -11 & -72 & 69 & 69 & -103 & -42 & -42 \\
\hline Federal \& Generating Public Losses & -2 & -2 & 20 & 35 & 4 & -4 & -28 & -27 & -32 & -12 & -12 & -18 & -13 & 9 \\
\hline IOU PSC Purchase & -150 & -150 & -150 & -150 & -150 & -150 & -150 & -150 & -150 & -150 & -150 & -150 & -150 & -150 \\
\hline Exports & 15 & .15 & 15 & 0 & 0 & 0 & 0 & -1 & 0 & -1 & 51 & 118 & 117 & 117 \\
\hline Contracts Out & 1,192 & 1,192 & 1,274 & 1,274 & 1,192 & 1,252 & 1,252 & 1,252 & 1,233 & 1,233 & 1,233 & 1,192 & 1,274 & 1,213 \\
\hline Federal Diversity & -113 & -114 & -127 & -124 & -89 & -60 & -53 & -75 & -87 & -114 & -114 & -95 & -138 & -125 \\
\hline Extreme Weather Adjustment & 0 & 0 & 0 & 0 & -70 & -92 & -110 & -40 & 0 & 0 & 0. & 0 & 0 & $\underline{\underline{0}}$ \\
\hline Total Load Changes & 601 & 606 & 690 & 776 & 625 & 597 & 512 & 900 & 717 & 961 & 1,013 & 744 & 974 & 1,072 \\
\hline \multicolumn{15}{|c|}{ Resource Changes: (+, Resource Increase, - Resource Decrease) } \\
\hline Regulated Hydro & 118 & -21 & -15 & -7 & 7 & 23 & 141 & 311 & 824. & 1,259 & 1,031 & 446 & 11 & -706 \\
\hline Independent Hydro & & & 0 & & 0 & 0 & -1 & & -1 & -1 & & 0 & 0 & -1 \\
\hline Sustained Peaking Adjustment & $-1,606$ & $-1,551$ & -899 & $-1,568$ & $-1,549$ & $-1,063$ & $-5,203$ & $-3,602$ & $-4,618$ & -813 & 947 & -21 & 3,302 & 3,201 \\
\hline Imports & 200 & 200 & 200 & & 118 & 118 & 118 & 118 & 118 & 118 & 0 & 0 & 0 & 0 \\
\hline Contracts In & 67 & 67 & 67 & 67 & 67 & 67 & 68 & 65 & 68 & 63 & 63 & 10 & 10 & 0 \\
\hline WNP-2 & 20 & 20 & 20 & 20 & 20 & 20 & 20 & 20 & 20 & 20 & 0 & 0 & $-1,155$ & 15 \\
\hline Non-Utility Generation & 0 & 0 & $\mathbf{0}$ & 0 & 0 & 0 & 1 & 1 & 1 & 1 & 1 & 1 & 1 & 1 \\
\hline Hydro Reserves & -6 & 1 & 1 & 0 & 0 & -2 & -7 & -15 & -41 & -63 & -51 & -23 & -1 & \\
\hline Large Thermal Reserves & -3 & -3 & -3 & -3 & -3 & -3 & -3 & -3 & -3 & -3 & 0 & 0 & 173 & -2 \\
\hline Spinning Reserves & 35 & 38 & 22 & 37 & 37 & 24 & 123 & 80 & 93 & -10 & -47 & 0 & -41 & -62 \\
\hline DSI Operating Reserves & -58 & .58 & .58 & -42 & .36 &.-37 & -26 & -21 & -22 & -21 & -21 & -21 & -22 & 40 \\
\hline $\begin{array}{l}\text { Miscellaneous } \\
\end{array}$ & 1 & 0 & -1 & -2 & -1 & 2 & -1 & -1 & 0 & 0 & -1 & -1 & 0 & 0 \\
\hline Total Resource Changes & $-1,232$ & $-1,307$ & -666 & $-1,498$ & $-1,340$ & -851 & $-4,770$ & $-3,047$ & $-3,561$ & 550 & 1,923 & 391 & 2,278 & 2,522 \\
\hline $\begin{array}{l}\text { Difference: } 1993 \text { Study Less } 1994 \text { Study } \\
\text { Resource Changes - Load Changes }\end{array}$ & 833 & $-1,913$ & $-1,356$ & $-2,274$ & $-1,965$ & $-1,448$ & $-5,282$ & $-3,947$ & $-4,278^{-}$ & -411 & 910 & -353 & 1,304 & 1,450 \\
\hline $\begin{array}{l}\text { 1994 Federal System Firm Energy } \\
\text {. Surplus/Deficit }{ }^{3}\end{array}$ & 2,949 & $.3,275$ & 2,179 & 1,196 & 1,197 & 1,581 & $-1,719$ & $-1,364$ & 817 & 4,262 & 4,731 & 5,068 & 3,985 & 4,541 \\
\hline
\end{tabular}

${ }^{1}$ Operating Year (OY) is the 12-month period August 1 through July 31. For example, OY 1995-96 is August 1, 1995, through July 31, 1996.

21993 Pacific Northwest Loads and Resources Study, December 1993, Exhibit 11, page 84.

3 1994 Pacific Northwest Loads and Resources Study. December 1994, Exhibit 5, page 56. 


\section{REGIONAL ANALYSIS}

The regional loads and resources analysis is based on the following assumptions:

- Capacity surplus vàlues do not reflect potential nighttime return problems on the region's system.

- The Pacific Northwest Coordination Agreement, which expires June 30,2003 , is replaced with a like agreement;

- BPA's power sales contracts with Pacific Northwest Federal and public agencies, IOUs, and DSIs, which expire June 30, 2001, are renewed with like agreements;

- All existing regional contractual arrangements not included under Pacific Northwest power sales contracts expire and are not renewed;

- All Federal Southwest surplus firm power sales are shown as power sales through their expiration; and

- Extreme weather adjustments were included for the months of November through February. These adjustments vary monthly from 3,700 to 4,100 peak megawatts under the medium load forecast.
This analysis includes current operating requirements adopted by the hydroelectric project owners, and incorporates the NMFS Draft Biological Opinion dated March 16,1994.

\section{Regional Firm Energy Loads}

Regional firm energy loads for OY 1995 96 through 2004-05 based on BPA's 1994 medium load forecast are shown in Figure 6, page 34 . The load projections also include all intra-regional contracts made by Pacific Northwest utilities and the Federal system, and additional conservation reductions described in Conservation Reductions, page 10. The average annual rate of growth for the period from OY 1995-96 through 2004-05 is 1.0 percent per year under the medium load growth scenario. The regional firm energy load for the medium load forecast is presented on line 4 in Exhibit 9, pages 70 through 71, and the monthly firm loads for OY 1995-96, 1999-2000, and 2004-05 under the medium load forecast are presented in Exhibits 10 through 12, pages 74 through 79. 
Figure 6

Regional Firm Loads

1994 BPA Forecast

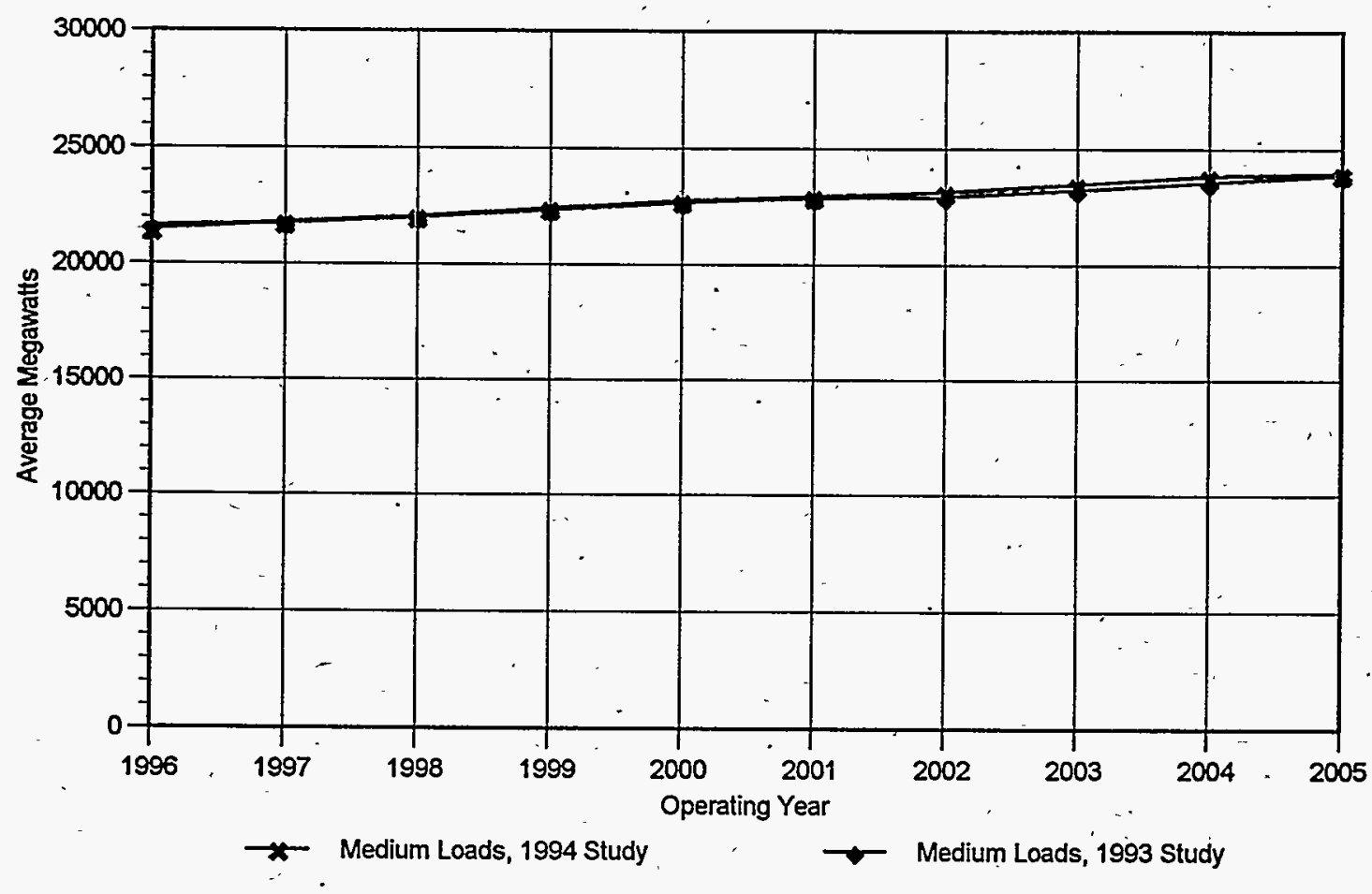

MPMO: $12 / 94$

\section{Regional Firm Peak Loads}

Figure 7 , page 35 , illustrates the regional firm peak loads under the medium load forecast for OY 1995-96, 1999-2000, and 2004-05. The figures show the expected 1-hour monthly. demand under the 1994 BPA load forecast and include extreme ' weather adjustments. Extreme weather conditions were assumed for the months of November through February and estimate a 5-percent probability that the forecasted peak load will be exceeded. In the months of March through October, the peak loads estimate normal weather conditions with a 50-percent probability that the forecasted peak load will be exceeded. - The projected regional peak loads include all intra-regional contracts made by Pacific Northwest utilities, including the Federal system. The peak load projections are decreased by a diversity factor due to the fact that all peak electrical demands do not occur simultaneously throughout the region.

The monthly regional firm peak loads are presented on line 4 , and the extreme weather adjustments to the regional peak loads are presented on line 37, of Exhibits 14 through 16 , pages 84 through 89 , for the medium load forecast. 
Figure 7

\section{Regional Firm Peak Loads for OY 1995-96, 1999-2000, and 2004-05 Under Extreme Weather Conditions Medium Loads}

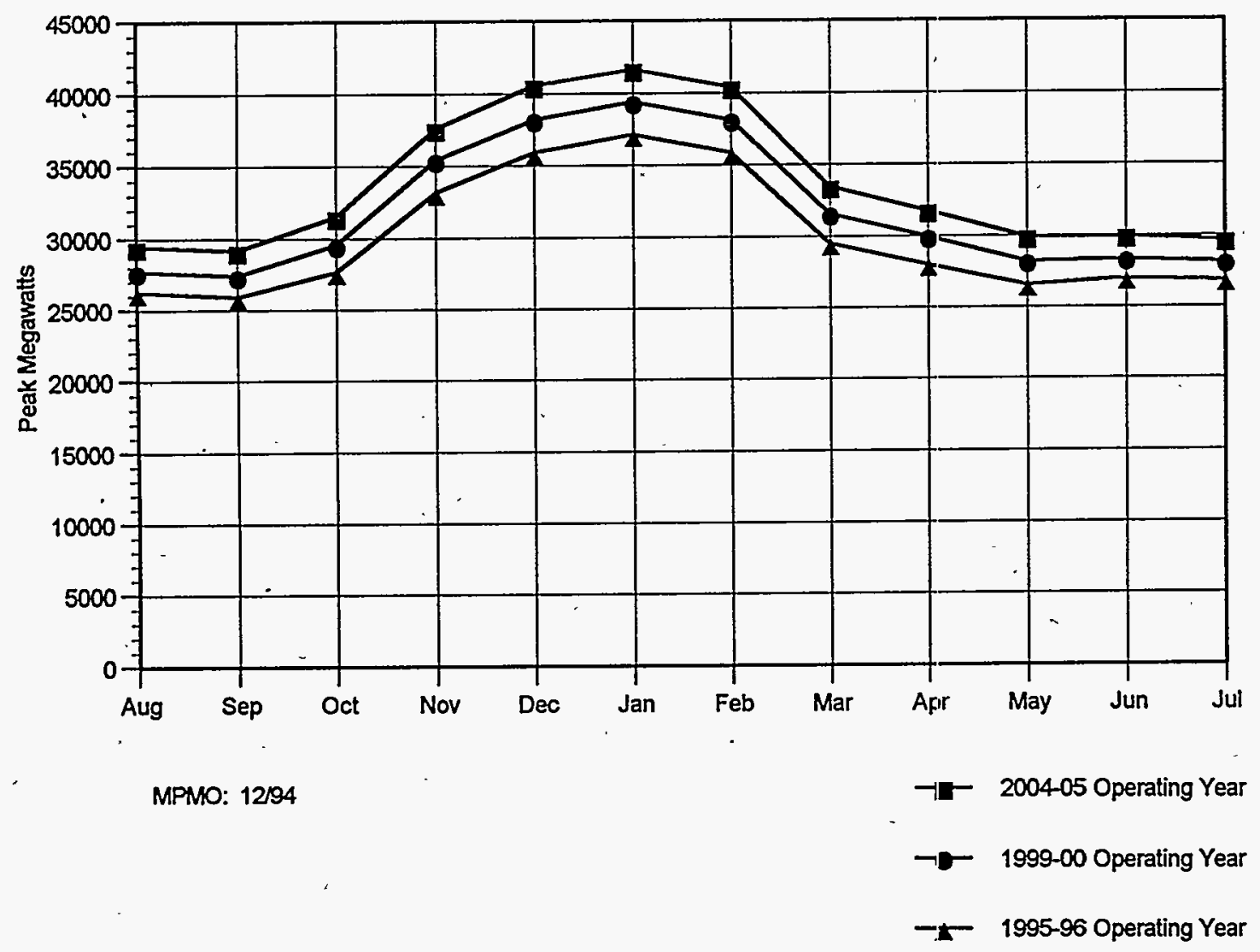




\section{Regional Firm Resources}

Table 11 summarizes the regional system resources for OY 1995-96. Hydroelectric resources make up a smaller percentage of the regional resources than of the Federal system resources because most of the thermal resources are owned by investor- owned utilities in the region. These thermal resources are composed primarily of IOUowned coal and nuclear plants. A detailed listing of all regional generating resources is contained in the 1994 Pacific Northwest Loads and Resources Technical Appendix: Volume 1 (available February 1995).

\section{Table 11}

Regional Firm Resources for OY 1995-961

Capacity based on January 1996

\begin{tabular}{|l|c|c|c|c|}
\hline Project Type & $\begin{array}{c}\text { Sustained } \\
\text { Peak Capac- } \\
\text { ity (MW) }\end{array}$ & $\begin{array}{c}\text { Generating } \\
\text { Peak } \\
\text { Capacity } \\
\% \text { of Total }\end{array}$ & $\begin{array}{c}\text { Firm Energy } \\
\text { (aMW) }\end{array}$ & $\begin{array}{c}\text { Firm Energy } \\
\% \text { of Total }\end{array}$ \\
\hline Hydro & 26,504 & $70^{\circ}$ & 12,312 & 60 \\
\hline Coal & 4,410 & 12 & 3,862 & 19 \\
\hline Nuclear & 1,170 & 3 & 819 & 4 \\
\hline Imports & 2,634 & 7 & 1,734 & 8 \\
\hline Combustion Turbines & 1,416 & 4 & 544 & 3 \\
\hline Non-Utility Generation & 1,139 & 3 & 1,012 & 5 \\
\hline Miscellaneous & 538 & 1 & 363 & 1 \\
\hline \hline TotAL Resources & 37,811 & 100 & 20,646 & 100 \\
\hline
\end{tabular}

${ }^{1}$ Operating Year (OY) is the 12-month period August 1 through July 31. For example, OY 1995-96 is August 1, 1994 through July 31, 1995. 
Regional Nonfirm Resources

As previously discussed, BPA uses critical water flows to compute the regional hydro firm energy for resource planning. Nonfirm energy is created when the region's hydro projects experience water flows greater than critical period levels.

Regional planning does not include nonfirm energy in the loads and resources balance. Nonfirm energy can vary from zero in the worst water year, to as much as 8,300 average megawatts in the best water year. The average annual nonfirm energy increases regional resources by about 3,800 to 4,200 average megawatts when averaged over 50 years of historical water flows.

The augmented Columbia and Snake River flows in the NMFS Draft Biological Opinion dated March 16, 1994 further changed the shape and amount of usable nonfirm energy.

\section{Regional Firm Energy Surpluses/Deficits}

This study includes all operating requirements currently adopted by the hydroelectric project owners and the firm planning assumptions from the NMFS Draft Eliological Opinion dated March 16, 1994

The regional critical period firm hydro energy shows a net decrease in this study compared to last year's study due to revised hydro project parameters, the impacts of the CRFA, changes in the shape of Columbia River generation, and up-grades at existing hydro projects.

The regional firm energy surpluses/ deficits for the medium load forecast for OY 1995-96 through 2004-05 are presented in Table 12, and depicted graphically in Figure 8, page 38. The region experiences firm energy deficits in OY 1995-96 under the medium load forecast.

The components of the regional energy loads and resources balances for the medium load scenario is presented on line 38 in Exhibit 9, page 70. Monthly regional firm energy loads under the medium load forecast for OY 1995-96, 1999-2000, and 2004-05 are presented in Exhibits 10 through 12, on pages 74 through 79 . 


\section{Table 12}

\section{Regional Firm Energy Surpluses/Deficits Assuming Existing Loads, Resources, and Contracts \\ Energy In Average Megawatts}

\begin{tabular}{|l|l|l|l|l|l|l|l|l|l|l|}
\hline & \multicolumn{10}{|c|}{ OPERATING YEAR 1} \\
\cline { 2 - 11 } & 1996 & 1997 & 1998 & 1999 & 2000 & 2001 & 2002 & 2003 & 2004 & 2005 \\
\cline { 2 - 10 } Medium Load Scenario & -834 & -928 & $-1,040$ & $-1,399$ & $-1,770$ & $-1,933$ & $-2,290$ & $-2,573$ & $-2,899$ & $-3,117$ \\
\hline
\end{tabular}

\section{Figure 8}

- Regional Firm Energy Surpluses/Deficits

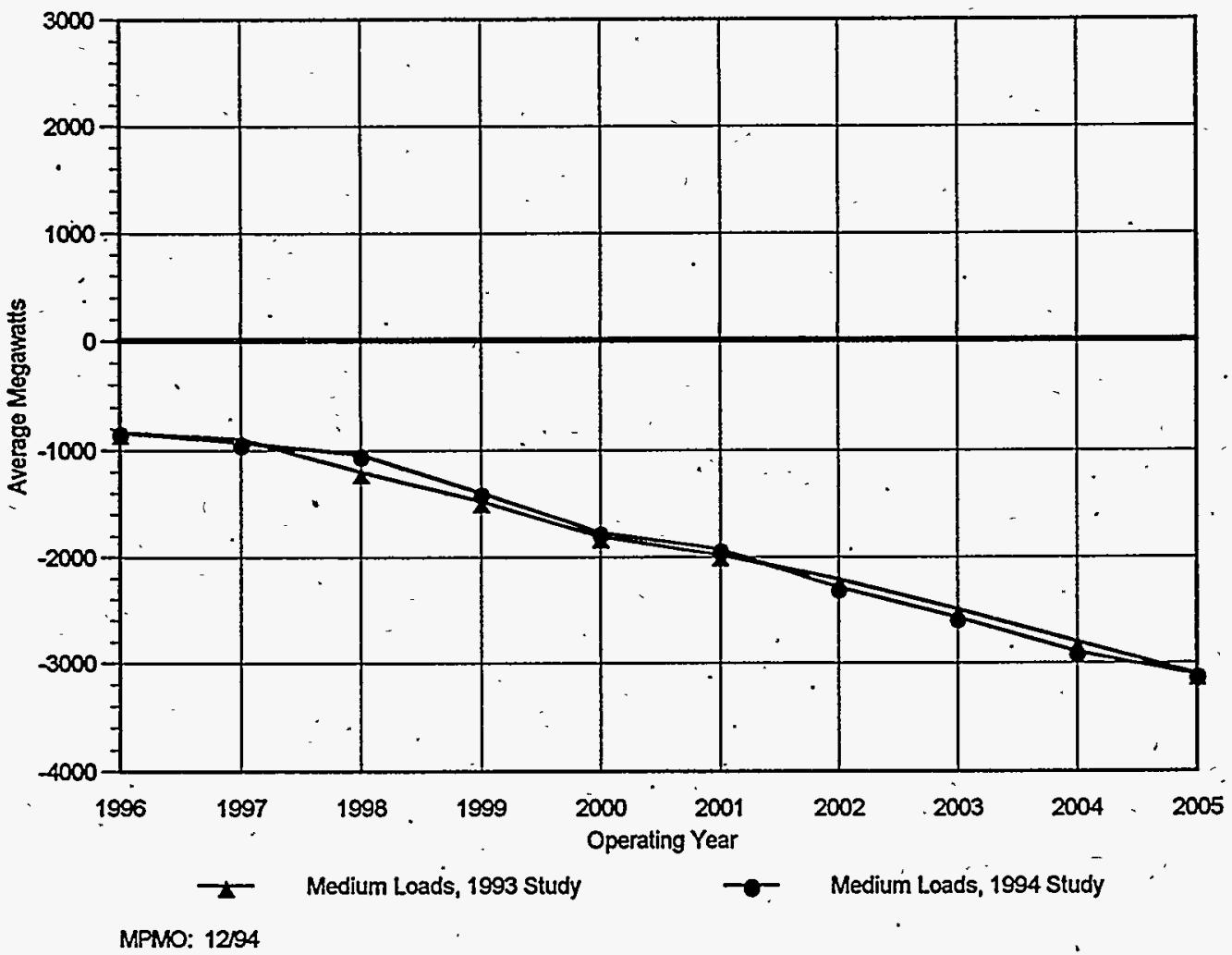

${ }^{1}$ Operating Year (OY) is the 12-month period August 1 through July 31. For example, OY 1995-96 is August 1, 1995, through July 31, 1996. 


\section{Regional Firm Capacity Surpluses/Deficits}

Figure 9 , page 40 , shows the region's firm 50-hours-per-week capacity surpluses/ deficits under the medium load forecast for OY 1995-96, 1999-2000, and 2004-05. This analysis incorporates all operating restrictions currently adopted by the hydroelectric project owners and the firm planning assumptions from the NMFS Draft Biological Opinion dated March 16, 1994.

The regional firm capacity surpluses/ deficits incorporate the regional assumptions on page 33 .

It is important to note that the capacity surplus values do not reflect potential nighttime return problems on the region's system. Peaking replacement energy from capacity sales is returned at night, when the output of the hydro system and other regional resources could be greater than the region's nighttime load. The following factors contribute to nighttime overgeneration:
- Low regional. system loads;

- Nonpower hydro requirements that dictate minimum streamflows; and

- The inability of the region's thermal resources to cycle from day to night.

These requirements restrict the ability to accept nighttime return energy, even though there is surplus generating capability during the daytime. These requirements are common in summer and fall, when the region's nighttime loads are low. Depending on water availability and economic conditions, return energy from these contracts could create low-priced forced energy sales and may reduce the region's ability to meét firm loads.

A 10-year summary of regional firm capacity surpluses/deficits for the medium load forecast is shown in Exhibit 13, page 82. Monthly firm capacity surpluses/deficits under the medium forecast for OY 1995-96, 1999-2000, and 2004-05 are presented in Exhibits 14 through 16 on pages 84 through 89 . 


\section{Figure 9}

\section{5-96 Regional Firm Capacity Surpluses/Deficits Under Extreme Weather Conditions'}

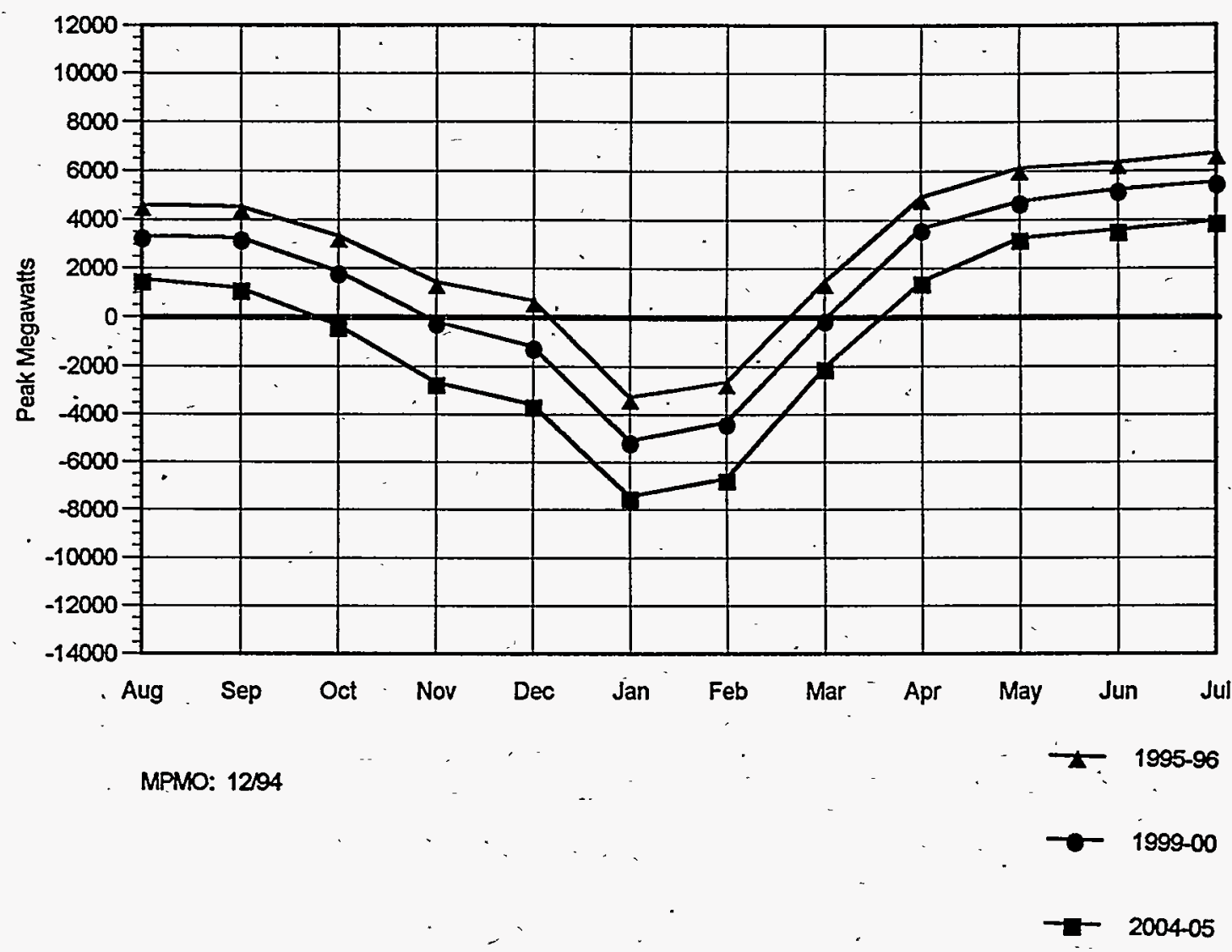

${ }^{\mathrm{I}}$ Extreme weather conditions in the months of November, December, January, and February assiume a 5-percent probability that the peak load will be exceeded. 


\section{SECTION VII \\ FEDERAL SYSTEM EXHIBITS}


THIS PAGE INTENTIONALLY LEFT BLANK.

42

Bonneville Power Administration 


\section{EXHIBIT 1 \\ FEDERAL SYSTEM CRITICAL PERIOD ENERGY ANALYSIS FOR 10 OPERATING Y'EARS}


SUMMARY OF FEDERAL SYSTEM LOADS AND RESOURCES IN THE PACIFIC NORTHWEST REGION UNDER THE PACIFIC NORTHWEST ELECTRIC POWER PLANNING AND CONSERVATION ACT

$M E D I U M \quad L O A D S$

OPERATING YEAR

1994 WHITEBOOK: $12 / 20 / 94$ RUN DATE: $12 / 20 / 94$

MEGAWATTS

1995-96 1996-97 1997-98 1998-99 $1999-0$ 2000- 1 2001- 2 2002- 3 2003- 4 2004- 5

LOADS FEDERAL AGENCIES

FEDERAL AGENCIES
FEDERAL \& GEN PUBLIC LOSSES USBR

4. DSI. ALUMINUM FIRM

5 DSI NON-ALUM FIRM

6 DSI FIRM LOSSES

SM \& NON GEN PUB PSC PUR I

8 FIRM SYSTEM LOAD

$\begin{array}{ccccc}1996-97 & 1997-98 & 1998-99 & 1999 \\ \text { AVG } & \text { AVG } & \text { AVG } & \text { AVG } & \text { AVG }\end{array}$

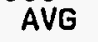
AVUG AVG

AVG AVG,

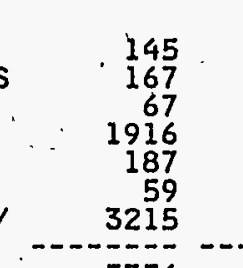

145
166
67
941
216

147
168
67
1941
217

3257

3122

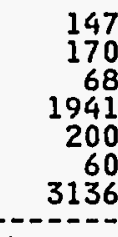

$\begin{array}{rr}47 & 148 \\ 70 & 171 \\ 68 & 67 \\ 1 & 1941 \\ 0 & 181\end{array}$

723

60

618
3194

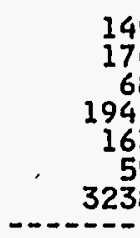

$\begin{array}{rr}149 & 1 \\ 174 & 150 \\ 68 & .175 \\ 141 & 1941\end{array}$

ANSFERS OUT

9 EXPORTS
10 CONTRACTS OUT
i1 CSPE TO WEST GROUP UTIL

12 GEN PUBLIC AGEN PSC PUR

13 IOU 'PSC PURCHASE

14 FED DIVERSITY

15 FIRM LOADS

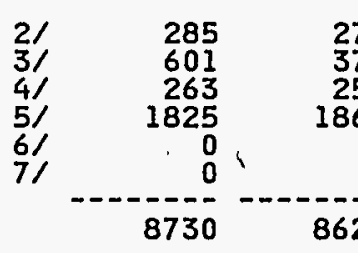

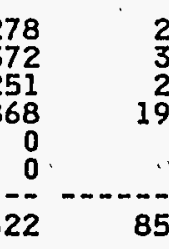

$\begin{array}{rr}276 & 396 \\ 394 & 395 \\ 236 & 178 \\ 1907 & 1960 \\ 0 & 0 \\ 0 & 0\end{array}$

5762

5792

161
59
3278

$\begin{array}{r}50 \\ 75 \\ 68 \\ 91 \\ 161 \\ 59 \\ 278 \\ \hline 832\end{array}$

151
177
68
1941

1941
160
59

59
3324

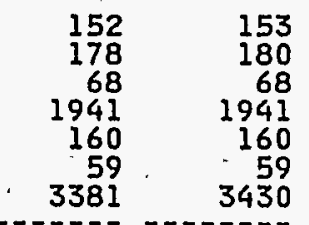

5880

5939

5991

TERRUPTIBLE LOADS

16 DSI ALUM TOP QUARTILE

17 DSI NON-ALUMINUM TO

19 TOTAL LOADS
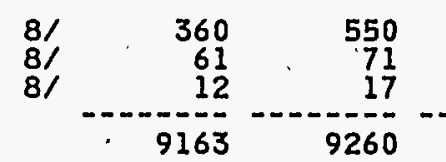

8536

8651

559
392
102
2028

558
365
98

5
8

555
341
94

1
4
0
0

$\begin{array}{rrr}634 & 788 & 777 \\ 341 & 341 & 341 \\ 62 & 0 & 0 \\ 2163 & 2222 & 2268\end{array}$

0 .

0

$8843 \quad 8881$

0

0
0

HYDRO RESOURCES

20 REGULATED HYDRO

21 INDY

$2 \% 297$

23. JUNE COL. RIVER FLOW AUG $9 /$

24 SUS. PKNG. ADUUSTMENT

26 CAN ENT NON-FED (CNDA)

27 RESTORATION

28 TOTAL HYDRO

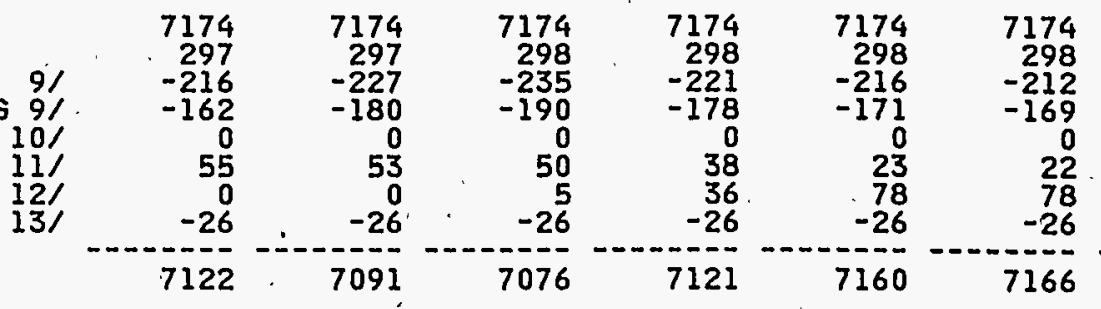

$\begin{array}{r}7174 \\ 298 \\ -206 \\ -162 \\ 0 \\ 21 \\ 77 \\ -26 \\ \hline 7176\end{array}$
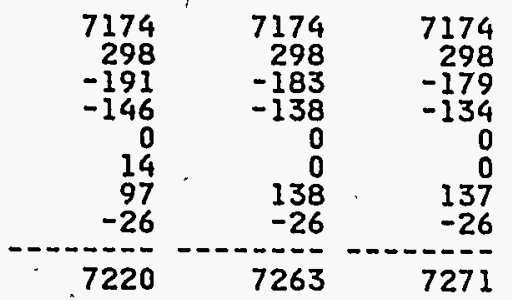
ABLE 2: FEDERAL SYSTEM (CONTINUED)

SUMMARY OF FEDERAL SYSTEM LOADS AND RESOURCES IN THE PACIFIC NORTHWEST REGION UNDER THE PACIFIC NORTHWEST ELECTRIC POHER PLANNING AND CONSERVATION ACT

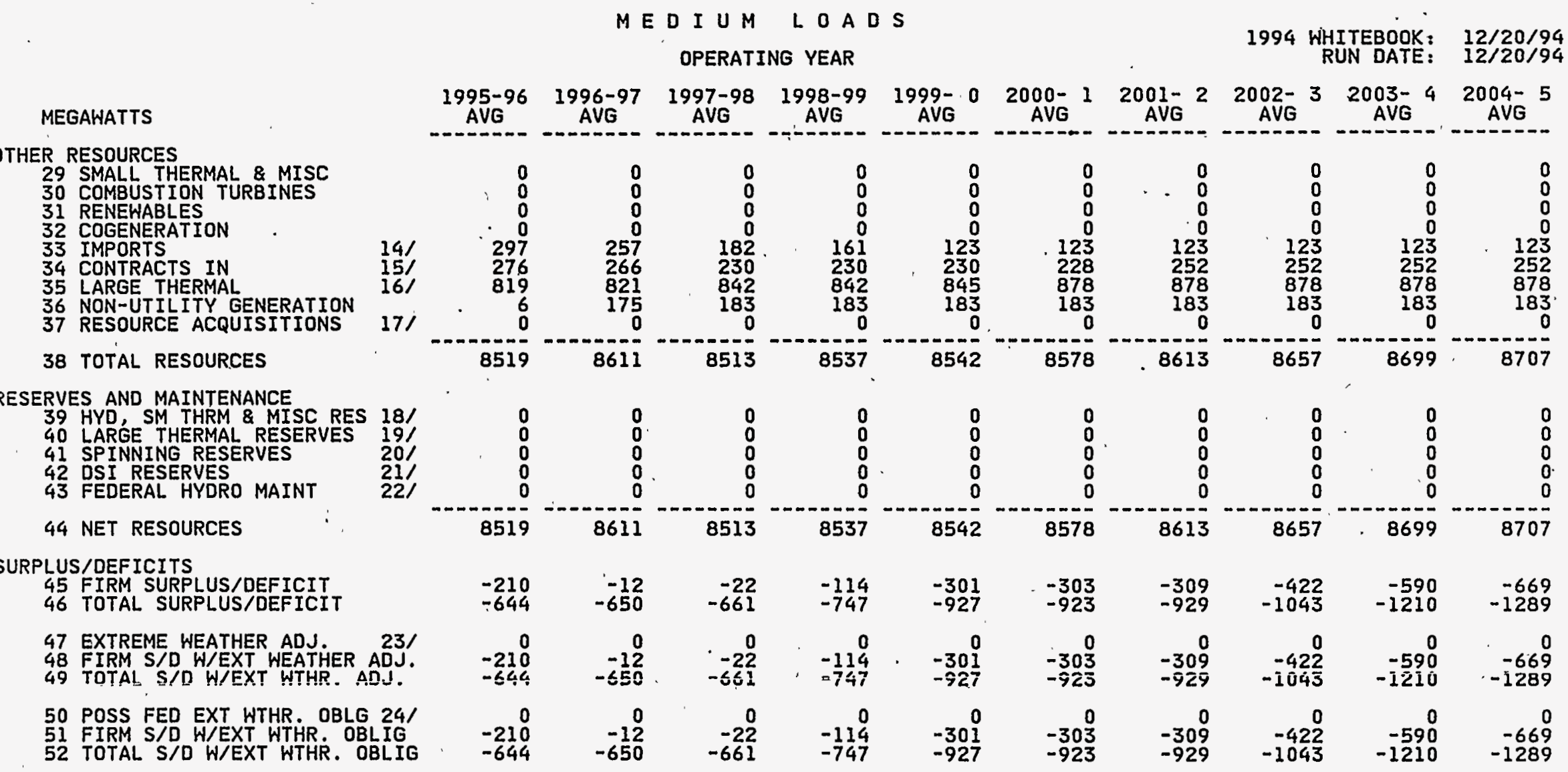

NOTE: 1. BPA SURPLUS POWER SALES CONTRACTS WITH THE PSW ARE SHOWN AS POWER SALES UNTIL THEY EXPIRE.

2. BPA SURPLUS POWER SALES CONTRACT WITH PSPEL IS SHOWN AS A POWER SALE THROUGH JUNE 30, 2001

3. THE FOLLOWING BPA CONTRACTS ARE RESOURCE OPTIONS AND NOT INCLUDED IN THIS ANALYSIS.

A. BGP TO BPA, SUPPLEMENTAL ENERGY

B. SCE TO BPA, SUPPLEMENTAL ENERGY 


\section{THIS PAGE INTENTIONALLY LEFT BLANK}


EXHIBITS 2 - 4

FEDERAL SYSTEM MONTHLY ENERGY ANALYSIS

- UNDER MEDIUM LOADS FOR 1930 WATER

CONDITIONS 
SUMMARY OF FEDERAL SYSTEM LOADS AND RESOURCES IN THE PACIFIC NORTHWEST REGION UNDER THE PACIFIC NORTHWEST ELECTRIC POWER PLANNING AND CONSERVATION ACT

MEDI U M LO A DS 1994 WHITEBOOK: $12 / 20 / 94$
RUN DATE:
$12 / 20 / 94$

1930 WATER YEAR

1995-96 OPERATING YEAR

ENERGY IN AVERAGE MEGAWATTS

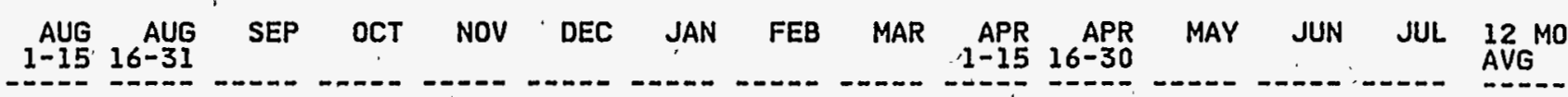

LOADS

FEDERAL AGENCIES.

$\begin{array}{lllllllllllllll}142 & 142 & 135 & 139 & 147 & 163 & 157 & 157 & 150 & 139 & 139 & 133 & 132 & 141 & 145\end{array}$

2 FEDERAL \& GEN PUBLIC LOSSES

USBR

4. OSI ALUMINUM FIRM

5 DSI NON-ALUM FIRM

6 DSI FIRM LOSSES

8 FIRM SYSTEM LOAD

$\begin{array}{rrrrrrrr}142 & 142 & 135 & 139 & 147 & 163 & 157 & 157 \\ 139 & 139 & 143 & 168 & 198 & 222 & 213 & 196 \\ 161 & 161 & 108 & 41 & 2 & 2 & 2 & 2 \\ 1858 & 1858 & 1858 & 1898 & 1898 & 1898 & 1935 & 1941 \\ 170 & 170 & 170 & 173 & 189 & 181 & 189 & 196\end{array}$

$53 \quad 53 \quad 53$

29892983

56

\begin{tabular}{lll}
189 & 196,194 \\
\hline & 196
\end{tabular}

153
49
1941

149

$\begin{array}{rrr}140 & 132 & 135 \\ 117 & 151 & 168\end{array}$

145
167
67

167
67
916

SFERS OUT

9 EXPORTS
10 CONTRACTS OUT
11 CSPE TO WEST GROUP UTIL
12 GEN PUBLIC AGEN PSC PUR
13 IOU PSC PURCHASE
14 FED DIVERSITY
15 FIRM LOADS

\begin{tabular}{rr}
$2 /$ & 380 \\
$3 /$ & 413 \\
$4 /$ & 268 \\
$5 /$ & 1546 \\
$6 /$ & 0 \\
$7 /$ & 0 \\
\hdashline & 8119
\end{tabular}

$\begin{array}{r}380 \\ 413 \\ 268 \\ 1562 \\ 0 \\ 0 \\ \hdashline 8130\end{array}$

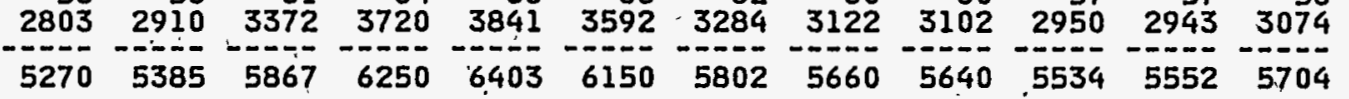

59
3216

5756

TERRUPTIBLE LOADS

16 DSI ALUM TOP QUARTILE

17 DSI NON-ALUMINUM TQ
18 TOP QUARTILE LOSSES

19 TOTAL LOADS

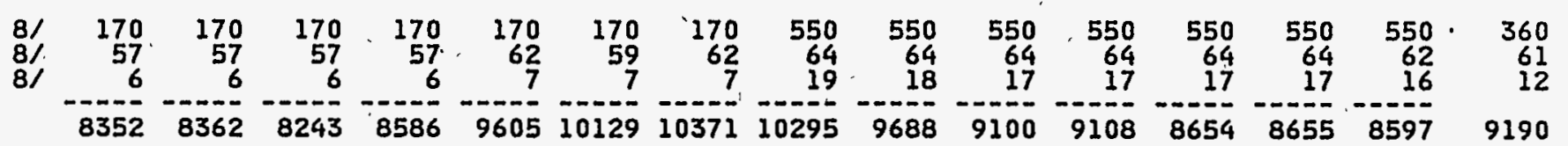

HYDRO RESOURCES

20 REGULATED HYDRO

21 INDEPENDENT HYDRO

22 MAY WATER BUDGE

23 JUNE COL. RIVER FLOW AUG 9',

24 SUS. PKNG. ADJUSTMENT

25 CAN. ENT. NON-FED(CSPE)

26 CAN. ENT: NON-FED(CNDA) 12

\begin{tabular}{rrrr}
$\prime$ & 6016 & 6228 & 5694 \\
& 407 & 356 & 321 \\
$9 /$ & 0 & 0 & \\
$9 \prime$ & 0 & 0 & \\
$10 /$ & 0 & 0 & \\
$11 /$ & 56 & 56 & 56 \\
$12 /$ & 0 & 0 & 0 \\
$13 /$ & -26 & -26 & -26 \\
\hline
\end{tabular}

$\begin{array}{lll}382 & 240 & 221 \\ 486 & 702 & 951 \\ 268 & 268 & 268\end{array}$

196

198
979

$\begin{array}{llllllll}187 & 189 & 185 & 222 & 389 & 420 & 398 & 284 \\ 938 & 789 & 503 & 503 & 162 & 224 & 57 & 601\end{array}$

263
1853

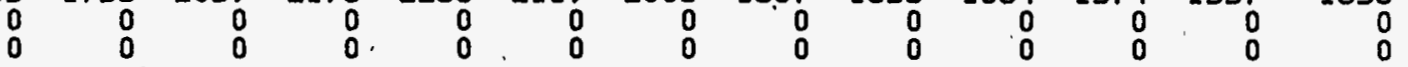

28 TOTAL HYDRO

$64536614 \quad 6045 \quad 6029$

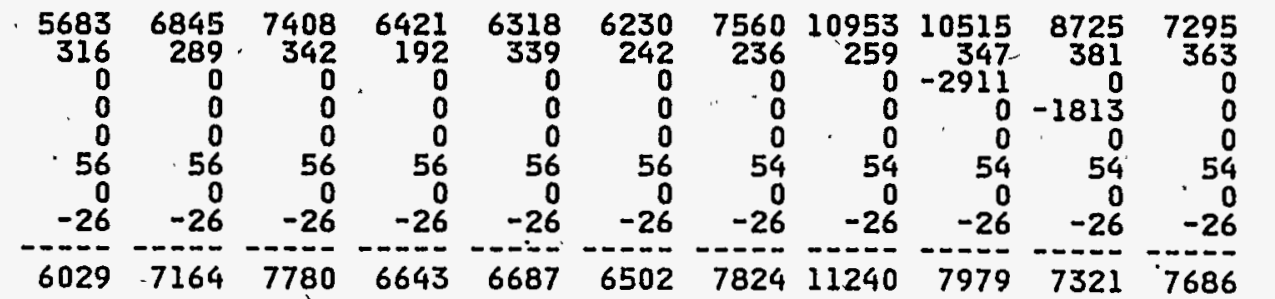

7209

$-243$

$-151$

0
55

$-26$

7158 
ABLE 2: FEDERAL SYSTEM (CONTINUED)

SHEET 2 OF 2

SUMMARY OF FEDERAL SYSTEM LOADS AND RESOURCES IN THE PACIFIC NORTHWEST REGION

UNDER THE PACIFIC NORTHWEST ELECTRIC POHER PLANNING AND CONSERVATION ACT

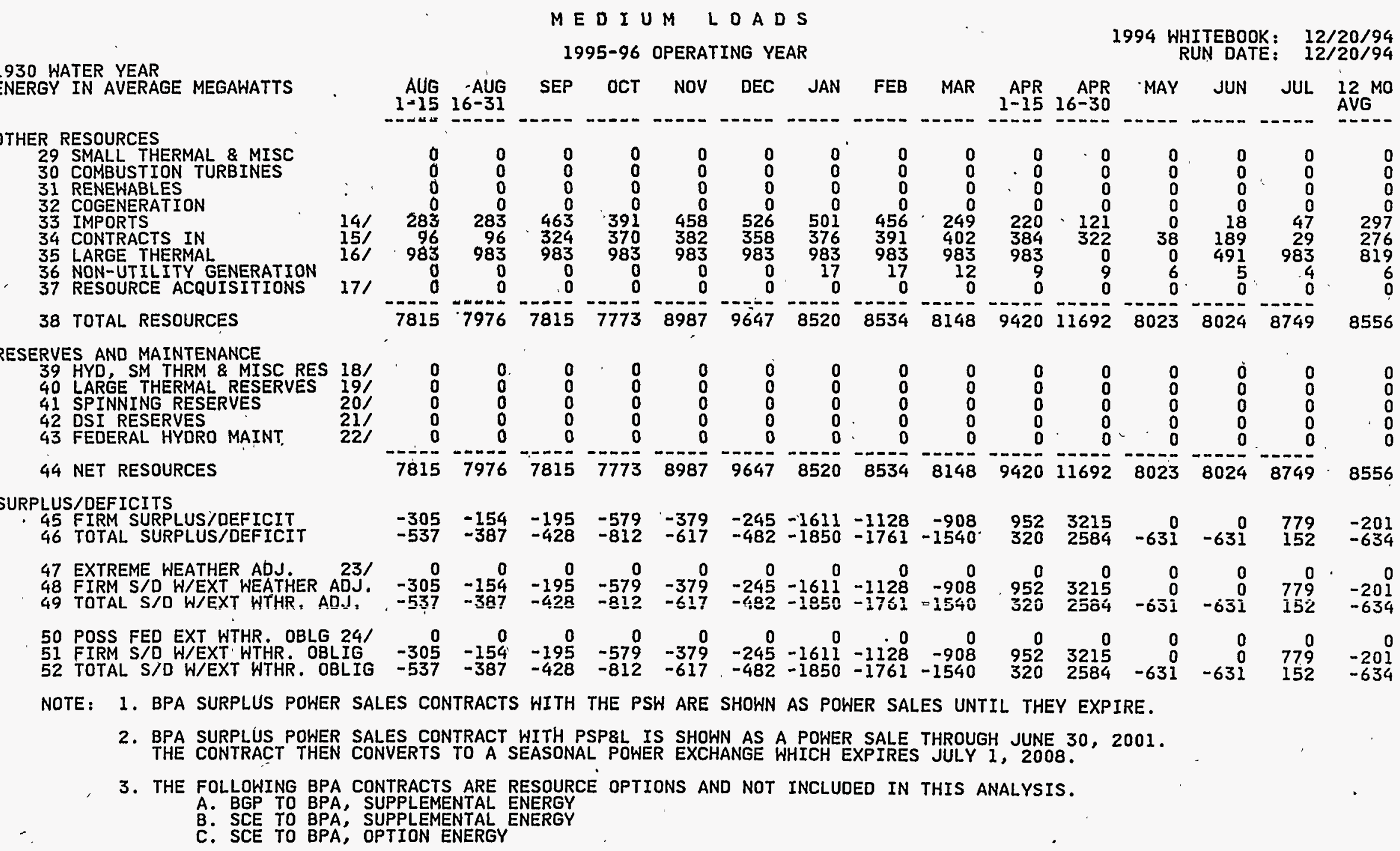


'

SUMMARY OF, FEDERAL SYSTEM LOADS AND RESOURCES IN THE PACIFIC NORTHWEST REGION UNDER THE PACIFIC NORTHWEST ELECTRIC POWER PLANNING AND CONSERVATION ACT

MEDIUM LOADS

1999- 0 OPERATING YEAR

1994 WHITEBOOK: $\quad 12 / 20 / 94$
RUN DATE: $\quad 12 / 20 / 94$

1930 WATER YEAR
ENERGY IN AVERAGE MEGAWATTS

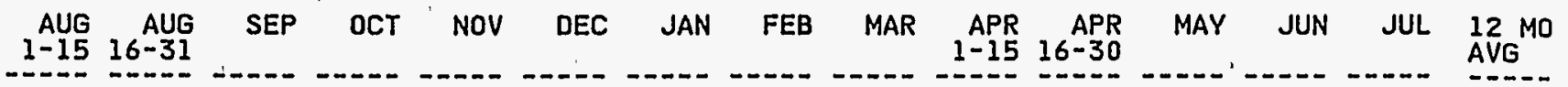

LOADS

1 FEDERAL AGENCIES

2 FEDERAL \& GEN PUBLIC LOSSES

3 USBR

4 DSI ALUMINUM FIRM

5 DSI NON-ALUM FIRM

6 DSI FIRM LOSSES

7. SM \& NON GEN PUB PSC PUR 11

8 FIRM SYSTEM LOAD $1-15$ 16-31

TRANSFERS OUT
9 EXPORTS
11 CSPE TO WEST GROUP UTIL
12 , GEN PUBLIC AGEN PSC PUR
13 IOU PSC PURCHASE
14 FED DIVERSITY
15 FIRM LOADS

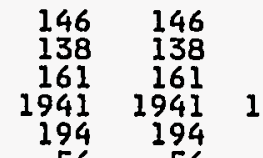

138
142
109
941

$\begin{array}{lll}56 & 56 & 192\end{array}$

562191

$\begin{array}{rrr}42 & 151 & 1 \\ 73 & 203 & 2 \\ 42 & 2 & \\ 41 & 1941 & 194 \\ 91 & 189 & 163\end{array}$

$\begin{array}{rr}67 & 161 \\ 30 & 2 \\ 2 & \\ 41 & 19 \\ 63 & 170\end{array}$

161
220
2
1941
1.70

$\begin{array}{rr}162 & 1 \\ 199 & 170 \\ 2 & \\ 1941, & 1941 \\ 185 & 183\end{array}$

154
170
4

$\begin{array}{rr}142 & 1 \\ 157 & 1 \\ 50 & \\ 1941 & 194\end{array}$

ERRUPTIBLE LOADS

16 DSI ALUM TOP QUARTILE

17 DSI NON-ALUMINUM TQ
18 TOP QUARTILE LOSSES

19 TOTAL LOADS

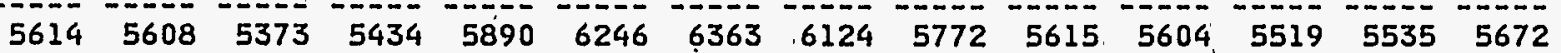

148

$\begin{array}{lllll}57 & 136 & 135 & 144 & 148 \\ 50 & 143 & 140 & 141 & 171\end{array}$

$\begin{array}{rrrr}50 & 117 & 151 & 169 \\ 91 & 1941 & 1941 & 1941\end{array}$

$\begin{array}{rrr}941 & 1941 & 1941 \\ 57 & 179 & 160\end{array}$

1941

181
60

3194

5762
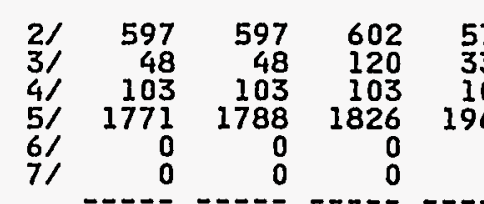

$\begin{array}{rr}579 & 547 \\ 337 & 782 \\ 103 & 103 \\ 1967 & 2264 \\ 0, & 0 \\ 0 & 0\end{array}$
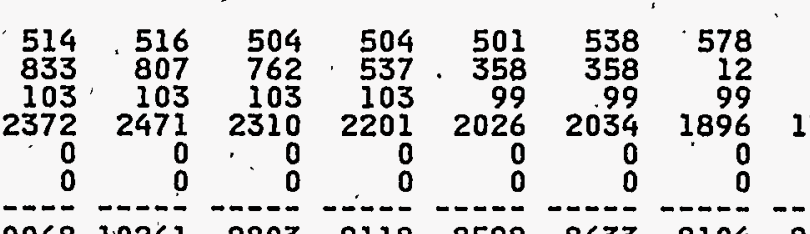

\begin{tabular}{rr}
621 & 616 \\
74 & 34 \\
99 & 99 \\
1782 & 1766 \\
0 & \\
0 & \\
\hline &
\end{tabular}

558
392
102
2056
0
$0 . \omega$

$8870^{-}$

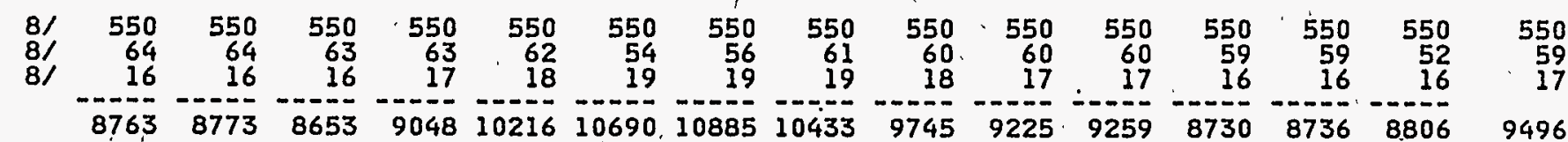

YDRO RESOURCES

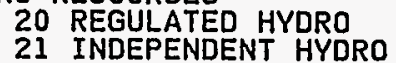

22 MAY WATER BUDGET

23 JUNE COL. RIVER FLOW AUG 9/

24 SUS. PKNG. ADJUSTMENT

25 CAN. ENT. NON-FED (CSPE)

27 RESTORATION

28 TOTAL HYDRO

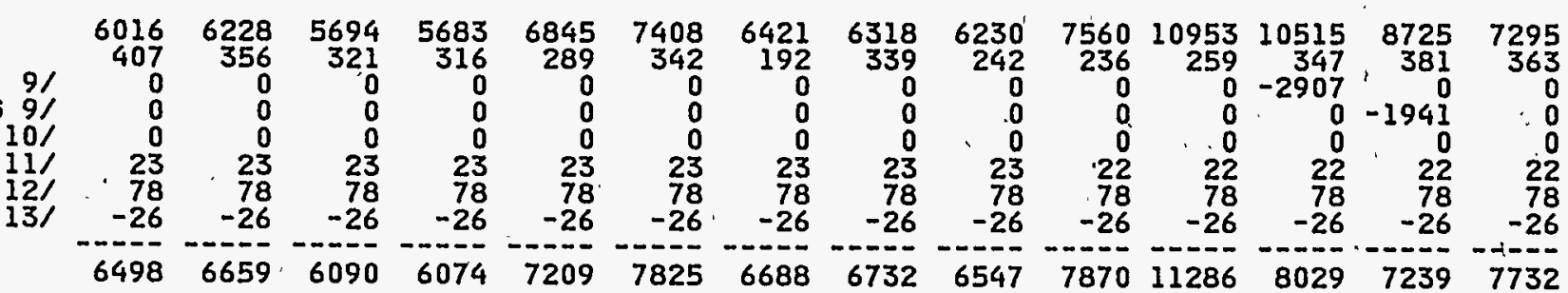

7209

313
-242

$-162$

23
78
-26

7193 
AABLE 2: FEDERAL SYSTEM (CONTINUED)

SUMMARY OF FEDERAL SYSTEM LOADS AND RESOURCES IN THE PACIFIC NORTHWEST REGION UNDER THE PACIFIC NDRTHWEST ELECTRIC POWER PLANNING AND CONSERVATION ACT

MEOIUM L OADS

1999- O OPERATING. YEAR

1994 WHITEBOOK: $12 / 20 / 94$

930 WATER YEAR

ENERGY IN AVERAGE MEGAWATTS

AUG
$1-15$ AUG
$-16-31$

SEP OCT NOV DEC JAN FEB MAR APR APR

MAY JUN JUL 12 MO

THER RESOURCES

29 SMALL THERMAL \& MISC

COMBUSTION TURBINES

31 RENEWABLES

33 COSORTS

34 CONTRACTS IN

35 LARGE THERMAL

36 NON-UTILITY GENERATION

37 RESOURCE ACQUISITIONS

38 TOTAL RESOURCES
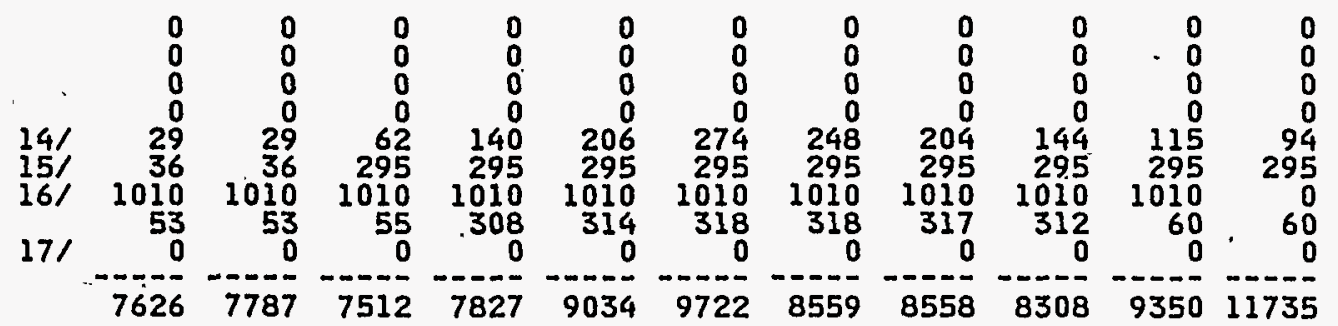

\begin{tabular}{rrrr}
0 & 0 & 0 & 0 \\
0 & 0 & 0 & 0 \\
0 & 0 & 0 & 0 \\
0 & 0 & 0 & 0 \\
4 & 0 & 18 & 50 \\
0 & 36 & 295 & 36 \\
0 & 0 & 505 & 1054 \\
0 & 40 & 54 & 53 \\
\hline 5 & 8104 & 0 & 0 \\
\hdashline 111 & 8925
\end{tabular} AVG

RESERVES AND MAINTENANCE

39 HYD, SM THRM \& MISC RES 18

40 LARGE THERMAL RESERVES $19 \%$

41 SPINNING RESERVES

42 DSI RESERVES

43 FEDERAL HYDRO MAINT

44 NET RESOURCES

181
191
211
221

\begin{tabular}{rrr}
0 & 0 & 0 \\
0 & 0 & 0 \\
0 & 0 & 0 \\
0 & 0 & 0 \\
0 & 0 & 0 \\
\hdashline 7626 & 7787 & 7512
\end{tabular}

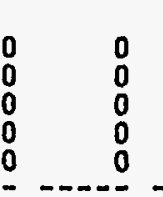

0
0
0
0
0
0
-

0
0
0
0
0
-
-

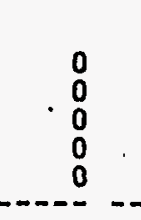

935011735

8576

SURPLUS/DEFICITS

45 FIRM SURPLUS/DEFICIT
46 TOTAL SURPLUS/DEFICIT

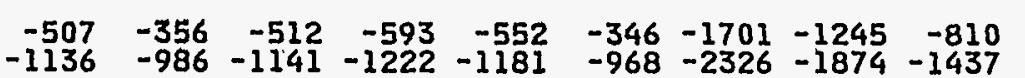

\begin{tabular}{lll}
0 & 0 & 0 \\
0 & 0 & 0 \\
0 & 0 & 0 \\
0 & 0 & 0 \\
0 & 0 & 0 \\
\hline
\end{tabular}

0
0
0
0
0

0
0
0
0
0

$\begin{array}{r}0 \\ 0 \\ 0 \\ 0 \\ 0 \\ \hdashline \\ \hdashline\end{array}$

$935011735 \quad 8104 \quad 81118925$

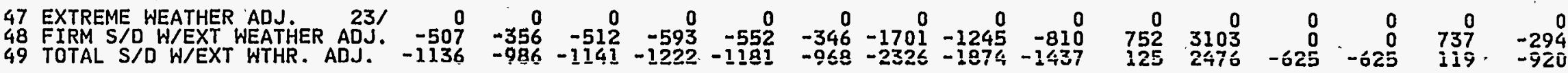
$\begin{array}{lllrrrrrrrrrrrrrrr}50 & \text { POSS FED EXT WTHR. OBLG 24/ } & 0 & 0 & 0 & 0 & 0 & 0 & 0 & 0 & 0 & 0 & 0 & 0 & 0 & 0 & 0 \\ 51 & \text { FIRM S/D W/EXT WTHR. OBLIG } & -507 & -356 & -512 & -593 & -552 & -346 & -1701 & -1245 & -810 & 752 & 3103 & 0 & 0 & 737 & -294 \\ 52 & \text { TOTAL S/D W/EXT WTHR. OBLIG } & -1136 & -986 & -1141 & -1222 & -1181 & -968 & -2326 & -1874 & -1437 & 125 & 2476 & -625 & -625 & 119 & -920\end{array}$

NOTE: 1. 'BPA SURPLUS POWER SALES CONTRACTS WITH THE PSW ARE SHOWN AS POWER SALES UNTIL THEY EXPIRE.

2. BPA SURPLUS POWER SALES CONTRACT WITH PSP\&L IS SHOWN AS A POWER SALE THROUGH JUNE 30, 2001.

3. THE FOLLOWING BPA CONTRACTS ARE RESOURCE OPTIONS AND NOT INCLUDED IN THIS ANALYSIS.

A. BGP TO BPA, SUPPLEMENTAL ENERGY

B. SCE TO BPA, SUPPLEMENTAL 
is TABLE 2: FEDERAL SYSTEM

SUMMARY OF FEDERAL SYSTEM LOADS AND RESOURCES IN THE PACIFIC NORTHWEST REGION UNDER THE PACIFIC NORTHWEST ELECTRIC POWER PLANNING AND CONSERVATION ACT

MEDIUM LOADS

2004- 5 OPERATING YEAR

1994 WHITEBOOK: $\quad 12 / 20 / 94$ RUN DATE: $12 / 20 / 94$

1930 WATER YEAR

ENERGY IN AVERAGE MEGAWATTS

AUG AUG

LOADS

FEDERAL AGENCIES

FEDERAL \& GEN PUBLIC LOSSES

DSI ALUMINUM FIRM

DSI NON-ALUM FIRM

SM \& NON GEN PUB PSC PUR $1 /$

8 FIRM SYSTEM LOAD

$1-1516-31$

OCT NOV DEC

AN FEB

MAR $:$ APR APR MAY JUN JUL 12 MVO

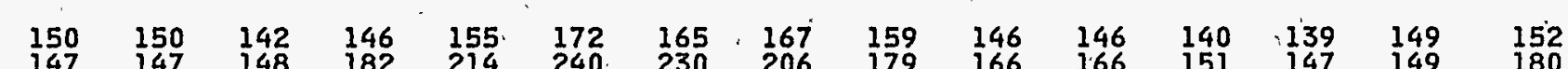

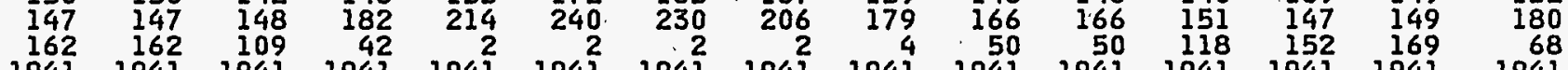

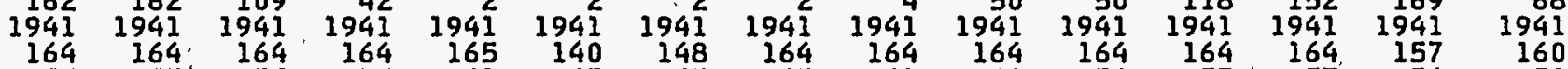

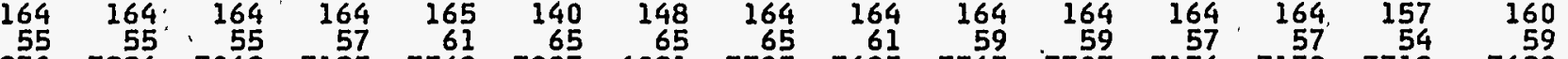

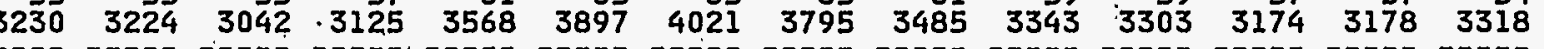

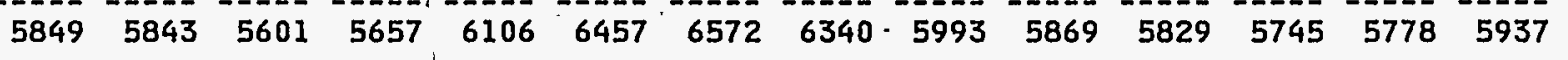

3429

5990

TRANSFERS OUT

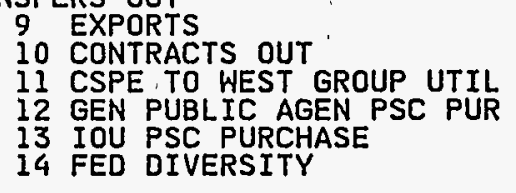

$2 j$
$3 \prime$
$4 \prime$
$5 \prime$
$6 \prime$
$7 \prime$

15 FIRM LOADS

INTERRUPTIBLE LOADS

16 DSI ALUM TOP QUARTILE

17 DSI NON-ALUMINUM TQ

18. TOP QUARTILE LOSSES

19 TOTAL LOADS

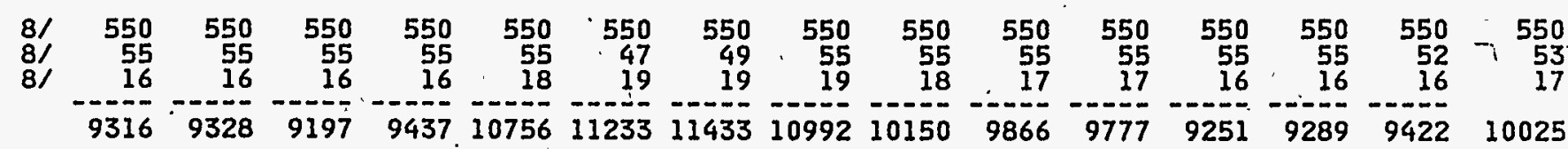

YDRO RESOURCES

20 REGULATED HYDRO

21 INDEPENDENT HYDRO

22 MAY WATER BUDGET

23 JUNE COL. RIVER FLOW AUG $9 /$

24 SUS. PKNG. ADJUSTMENT

25 CAN. ENT. NON-FED(CSPE)

26 CAN. ENT. NON-FED(CNDA)

27 RESTORATION.

28. TOTAL HYDRO

61
91
91
$10 /$
121
$13 /$

$\begin{array}{rrrrr}6016 & 6228 & 5694 & 5683 & 6845\end{array}$

\begin{tabular}{rrr}
6845 & 7408 & 6421 \\
289 & 342 & 192 \\
0 & 0 & 0 \\
0 & 0 & 0 \\
0 & 0 & 0 \\
0 & 0 & 0 \\
137 & 137 & 137 \\
-26 & -26 & -26 \\
\hline 7245 & 7861 & 6724
\end{tabular}

$\begin{array}{rr}6318 & 6230 \\ 339 & 242 \\ 0 & 0\end{array}$

$\begin{array}{rr}242 & 7560 \\ 0 & 236\end{array}$

$\begin{array}{rr}7560 & 109 \\ 236 & 259 \\ 0 & \end{array}$

\begin{tabular}{rrrrr}
0 & 10953 & 10515 & 8725 & 7295 \\
0 & 259 & 347 & 381 & 363 \\
0 & 0 & -2390 & 0 & 0 \\
0 & 0 & 0 & -1414 & 0 \\
0 & 0 & 0 & 0 & 0 \\
0 & 0 & 0 & 0 & 0 \\
7 & 137 & 137 & 137 & 137 \\
6 & -26 & -26 & -26 & -26 \\
\hdashline 7 & 11323 & 8583 & 7803 & 7769
\end{tabular}

7209
313

$-199$

$-118$

$\begin{array}{rrrr}0 & 0 & 0 & \\ 0 & 0 & 0 \\ 137 & 137 & 137 \\ -26 & -26 & -26 & -26\end{array}$

$137 \quad 137$

$\begin{array}{lll}6534 & 6695 & 6126\end{array}$

61

$6768 \quad 6583$

\footnotetext{
11323
} 
SUMMARY OF FEDERAL SYSTEM LOADS AND RESOURCES IN THE PACIFIC NORTHWEST REGION UNDER THE PACIFIC NORTHWEST ELECTRIC POWER PLANNING AND CONSERVATION ACT

1930 WATER YEAR
ENERGY IN AVERAGE MEGAWATTS
OTHER RESOURCES
29 SMALL THERMAL \& MISC
30 COMBUSTION TURBINES
31 RENEWABLES
32 COGENERATION
33 IMPORTS
34 CONTRACTS IN
35 LARGE THERMAL
36 NON-UTILITY GENERATION
37 RESOURCE ACQUISITIONS
38 TOTAL RESOURCES

\begin{tabular}{|c|c|c|c|c|c|c|c|c|c|c|c|c|c|c|c|}
\hline & . & & $\begin{array}{l}M \\
2\end{array}$ & $\begin{array}{l}D I \\
104-5\end{array}$ & $\begin{array}{l}M \\
\text { OPERA }\end{array}$ & NG $Y$ & SAR & & & & & 994 & $\begin{array}{l}{[T E B} \\
\text { JN D }\end{array}$ & & $\begin{array}{l}20 / 94 \\
20 / 94\end{array}$ \\
\hline & $\begin{array}{r}\text { AUG } \\
1-15\end{array}$ & $\begin{array}{r}\text { AUG } \\
16-31\end{array}$ & SEP & OCT & Nov & DEC & JAN & FEB & MAR & $\begin{array}{r}\text { APR } \\
1-15\end{array}$ & $\begin{array}{r}A P R \\
16-30\end{array}$ & MAY & JUN & JUL & 12 MO \\
\hline $\begin{array}{l}14 / \\
15 / \\
16 / \\
17 /\end{array}$ & $\begin{array}{r}0 \\
0 \\
1 \quad 0 \\
0 \\
29 \\
159 \\
1054 \\
53 \\
0\end{array}$ & $\begin{array}{r}0 \\
0 \\
0 \\
0 \\
29 \\
159 \\
1054 \\
53 \\
0\end{array}$ & $\begin{array}{r}0 \\
0 \\
0 \\
0 \\
62 \\
418 \\
1054 \\
55 \\
0\end{array}$ & $\begin{array}{r}0 \\
0 \\
0 \\
0 \\
140 \\
418 \\
1054 \\
308 \\
0\end{array}$ & $\begin{array}{r}0 \\
0 \\
0 \\
0 \\
206 \\
266 \\
1054 \\
314 \\
0\end{array}$ & $\begin{array}{r}0 \\
0 \\
0 \\
0 \\
274 \\
266 \\
1054 \\
318 \\
0\end{array}$ & $\begin{array}{r}0 \\
0 \\
0 \\
0 \\
248 \\
266 \\
1054 \\
318 \\
0\end{array}$ & $\begin{array}{r}0 \\
0 \\
0 \\
0 \\
204 \\
266 \\
1054 \\
317 \\
0\end{array}$ & $\begin{array}{r}0 \\
0 \\
0 \\
0 \\
144 \\
266 \\
1054 \\
312 \\
0\end{array}$ & $\begin{array}{r}0 \\
0 \\
0 \\
0 \\
114 \\
266 \\
1054 \\
60 \\
0\end{array}$ & $\begin{array}{r}0 \\
0 \\
0 \\
0 \\
93 \\
266 \\
0 \\
60 \\
0\end{array}$ & $\begin{array}{r}0 \\
0 \\
0 \\
0 \\
0 \\
7 \\
0 \\
40 \\
0\end{array}$ & $\begin{array}{r}0 \\
0 \\
0 \\
0 \\
18 \\
266 \\
527 \\
54 \\
0\end{array}$ & $\begin{array}{r}0 \\
0 \\
0 \\
0 \\
50 \\
159 \\
1054 \\
53 \\
0\end{array}$ & $\begin{array}{r}0 \\
0 \\
0 \\
0 \\
123 \\
252 \\
878 \\
183 \\
0\end{array}$ \\
\hline & 7829 & 7990 & 7714 & 8029 & 9085 & 9773 & 8610 & 8609 & 8359 & 9401 & 11742 & 8629 & 8668 & 9084 & -8754 \\
\hline $\begin{array}{l}18 / \\
19 \prime \\
20 \prime \\
21 \prime \\
22 \prime\end{array}$ & $\begin{array}{l}0 \\
0 \\
0 \\
0 \\
0\end{array}$ & $\begin{array}{l}0 \\
0 \\
0 \\
0 \\
0\end{array}$ & $\begin{array}{l}0 \\
0 \\
0 \\
0 \\
0\end{array}$ & $\begin{array}{l}0 \\
0 \\
0 \\
0 \\
0\end{array}$ & $\begin{array}{l}0 \\
0 \\
0 \\
0 \\
0\end{array}$ & $\begin{array}{r}0 \\
0 \\
0 \\
0 \\
0 \\
0\end{array}$ & $\begin{array}{l}0 \\
0 \\
0 \\
0 \\
0\end{array}$ & $\begin{array}{l}0 \\
0 \\
0 \\
0 \\
0\end{array}$ & $\begin{array}{l}0 \\
0 \\
0 \\
0 \\
0\end{array}$ & $\begin{array}{l}0 \\
0 \\
0 \\
0 \\
0\end{array}$ & $\begin{array}{l}0 \\
0 \\
0 \\
0 \\
0\end{array}$ & $\begin{array}{l}0 \\
0 \\
0 \\
0 \\
0\end{array}$ & $\begin{array}{l}0 \\
0 \\
0 \\
0 \\
0\end{array}$ & $\begin{array}{l}0 \\
0 \\
0 \\
0 \\
0\end{array}$ & $\begin{array}{l}0 \\
0 \\
0 \\
0 \\
0\end{array}$ \\
\hline & 7829 & 7990 & 7714 & 8029 & 9085 & 9773 & 8610 & 8609 & 8359 & 9401 & 11742 & 8629 & 8668 & 9084 & 8754 \\
\hline & -867 & -718 & -863 & -786 & -1048 & -844 & -2205 & -1760 & -1169 & 156 & 2587 & 0 & 0 & 280 & -651 \\
\hline
\end{tabular}

SURPLUS/DEFICITS

45 FIRM SURPLUS/DEFICIT
46 TOTAL SURPLUS/DEFICIT

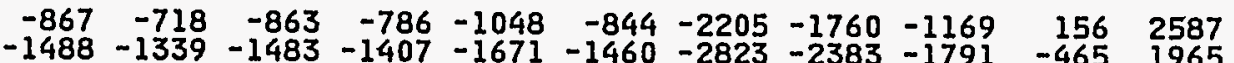

$\begin{array}{rrrr}0 & 0 & 280 & -651 \\ -621 & -621 & -338 & -1272\end{array}$

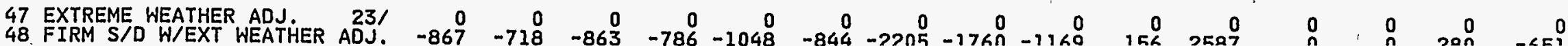

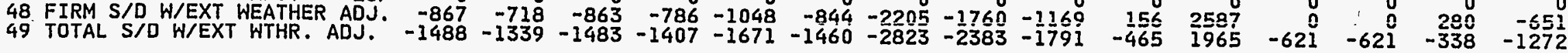

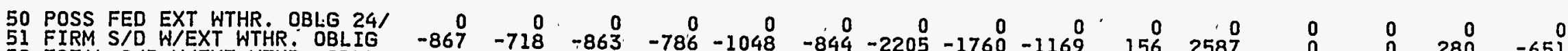

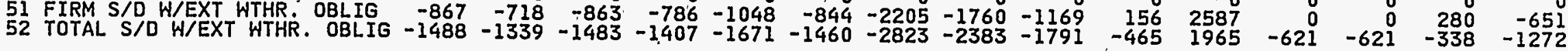

NOTE: 1. BPA SURPLUS POWER SALES CONTRACTS WITH THE PSW ARE SHOWN AS POWER SALES UNTIL THEY EXPIRE.

2. BPA SURPLUS POWER SALES CONTRACT WITH PSP\&L IS SHOWN AS A POWER SALE THROUGH JUNE 30, 2001.

THE CONTRACT THEN CONVERTS TO A SEASONAL POWER EXCHANGE WHICH EXPIRES JULY $1,2008$.

3. THE FOLLOWING BPA CONTRACTS ARE RESOURCE OPTIONS AND NOT INCLUDED IN THIS ANALYSIS.

A. BGP TO BPA, SUPPLEMENTAL ENERGY

B. SCE TO BPA, SUPPLEMENTAL ENERGY 
THIS PAGE INTENTIONALLY LEFT BLANK 
EXHIBIT 5

FEDERAL SYSTEM MONTHLY 50-HOUR CAPACITY SURPLUS/DEFICIT UNDER THE FIVE LOAD SCENARIOS FOR 1930 WATER CONDITIONS 
TABLE F-1: 50-HOUR SUSTAINED PEAKING

BASE CASE: EXISTING FEDERAL CONTRACTS

FEDERAL SYSTEM FIRM 50-HOUR CAPACITY SURPLUS/DEFICIT

INCLUDING EXTREME WEATHER ADJUSTMENTS DURING NOVEMBER THROUGH FEBRUARY

10 YEAR MONTHLY SUMMARY

ASSUMING NO NIGHTTIME RETURN CONSTRAINTS,

EXISTING FEDERAL CONTRACTS, AND NO NEW RESOURCE ACQUISITIONS

$$
\text { MEDIUM L OADS }
$$

1994 WHITEBOOK: $12 / 20 / 94$ RUN DATE: $12 / 20 / 94$

1930 WATER YEAR

AUG
$1-15$
$16-31$

PEAK IN MEGANATTS

$1995-96$
$1996-97$
$1997-98$
$1998-99$
$1999-00$
$2000-01$
$2001-02$
$2002-03$
$2003-04$
$2004-05$

$\begin{array}{llll}2949 & 3275 & 2179 & 1 \\ 2727 & 3057 & 2033 & 1 \\ 2952 & 3292 & 2456 & 1 \\ 2963 & 3306 & 2215 & 1 \\ 2854 & 3197 & 2110 & 1 \\ 2864 & 3204 & 2111 & 1 \\ 3162 & 3503 & 2387 & 1 \\ 3077 & 3418 & 2304 & 1 \\ 2649 & 2990 & 1892 & 1 \\ 2533 & 2874 & 1764 & 1\end{array}$

$\begin{array}{rr}1196 & 1197 \\ 1551 & 1450 \\ 1578 & 1434 \\ 1326 & 1150 \\ 1224 & 724 \\ 1222 & 678 \\ 1751 & 628 \\ 1646 & 497 \\ 1212 & 19 \\ 1078 & -152\end{array}$

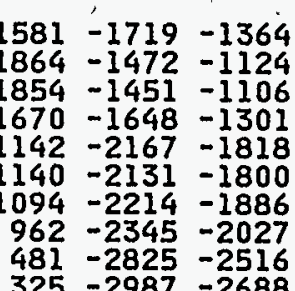

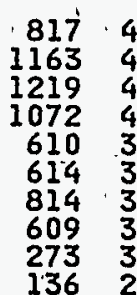
i

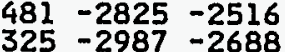

NOTE: 1. BPA SURPLUS POWER SALES CONTRACTS WITH THE PSH ARE SHOWN AS POWER SALES UNTIL THEY EXPIRE.

2. BPA SURPLUS POWER SALES CONTRACT WITH PSPEL IS SHOWN AS A POWER SALE THROUGH JUNE 30, 2001.

3. THE FOLOWING BPA
A. BGP TO BPA, SUPPLEMENTAL ENERGY
C. SCE TO BPA, OPTION ENERGY 
EXHIBITS 6 - 8

FEDERAL SYSTEM MONTHLY CAPACITY ANALYSIS UNDER MEDIUM LOADS FOR 1930 WATER CONDITIONS 
U) TABLE 2: FEDERAL SYSTEM

SUMMARY OF FEDERAL SYSTEM LOADS AND RESOURCES IN THE PACIFIC NORTHWEST REGION UNDER THE PACIFIC NORTHWEST ELECTRIC POWER PLANNING AND CONSERVATION ACT ASSUMING NO NIGHTTIME RETURN -CONSTRAINTS

ME D I U M L OADS

1995-96 OPERATING YEAR

1930 WATER YEAR

PEAK IN MEGAWATTS

LOADS

1 FEDER'AL AGENCIES

2. FEDERAL \& GEN PUBLIC LOSSES

3 USBR

4 DSI ALUMINUM FIRM

5 DSI NON-ALUM FIRM

6 DSI FIRM LOSSES

8 FIRM SYSTEM LOAD

RANSFERS OUT

9
10
1

15 FIRM LOADS

INTERRUPTIBLE LOADS

I6 DSI ALUM TOP QUARTILE

17 DSI NON-ALUMINUM TQ

19 TOTAL LOADS

20 REGULATED HYDRO

21 INDEPENDENT HYDRO

2 MAY WATER BUDGET

23 JUNE COL. RIVER FLOW AUG 9

24. SUS. PKNG. ADJUSTMENT

25 CAN. ENT. NON-FED (CSPE)

26 CAN: ENT: NON-FED (CNDA) 12

27 RESTORATION

28 TOTAL HYDRO

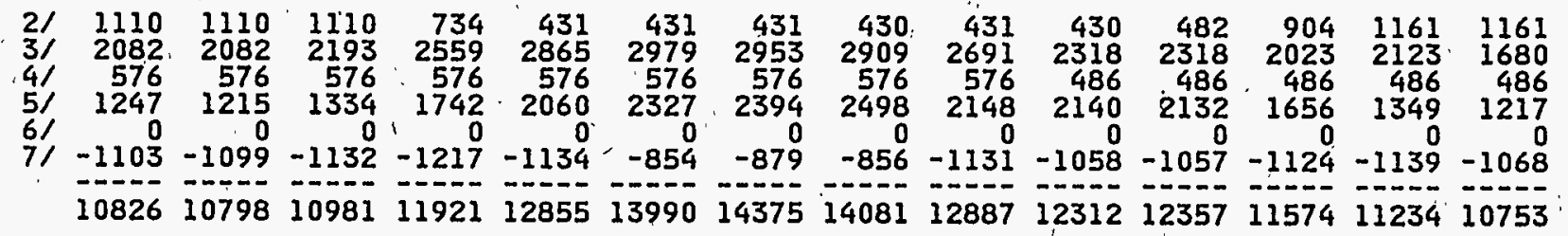

1994 WHITEBOOK: $12 / 20 / 94$ RUN DATE: $12 / 20 / 94$

AUG
$1-15$
$16-31$ SEP OCT NOV DEC JAN FEB MAR $\begin{gathered}\text { APR } \\ 1-15 \quad 16-30\end{gathered}$

\begin{tabular}{|c|c|c|c|c|c|c|c|c|c|c|c|c|c|}
\hline $\begin{array}{r}209 \\
199 \\
1886 \\
189\end{array}$ & $\begin{array}{r}191 \\
209 \\
199 \\
1886 \\
189 \\
60 \\
4180\end{array}$ & $\begin{array}{r}182 \\
242 \\
157 \\
1886 \\
189 \\
62 \\
4181\end{array}$ & $\begin{array}{r}191 \\
305 \\
75 \\
1927 \\
193 \\
68 \\
4767\end{array}$ & $\begin{array}{r}199 \\
351 \\
7 \\
1927 \\
210 \\
+75\end{array}$ & $\begin{array}{r}228 \\
388 \\
4 \\
1927 \\
201 \\
79\end{array}$ & $\begin{array}{r}213 \\
401 \\
4 \\
1965 \\
210 \\
85\end{array}$ & 3 & $\begin{array}{r}20 \\
31 \\
197 \\
21 \\
7\end{array}$ & $\frac{1}{2}$ & $\frac{1}{2}$ & 2 & 3 & \\
\hline & 691 & 689 & 75 & 0 & & 89 & & & & & & & \\
\hline
\end{tabular}

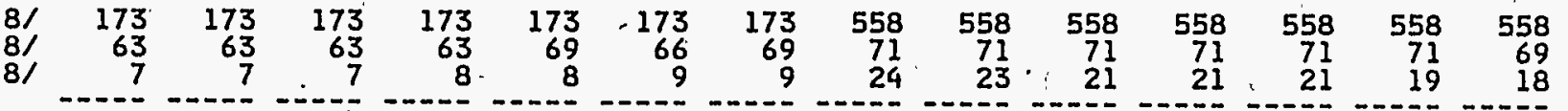

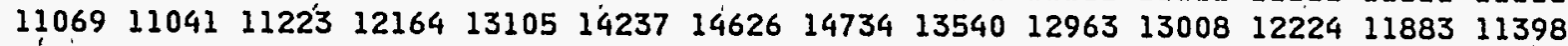

2026920494205242058120945209152088420844206682004619713194651967319636

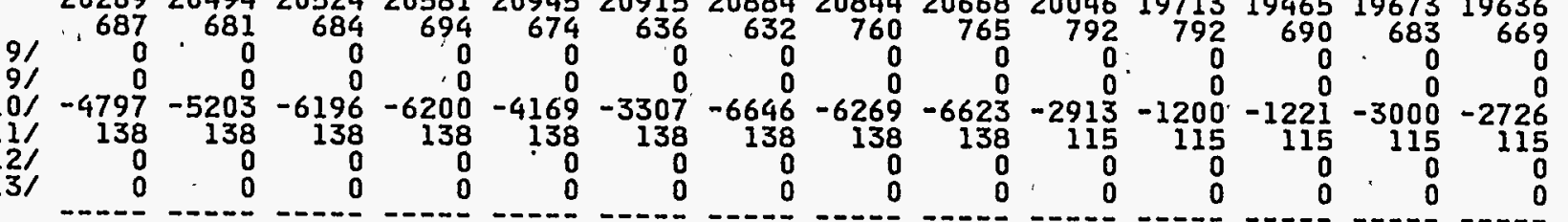

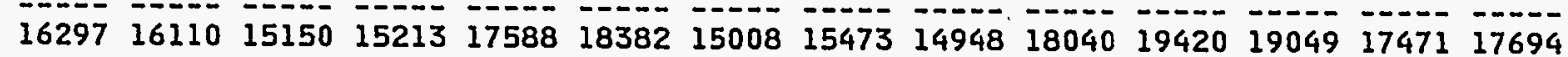


TABLE 2: FEDERAL SYSTEM (CONTINUED)

SUMMARY OF FEDERAL SYSTEM LOADS AND RESOURCES IN THE PACIFIC NORTHWEST REGION UNDER THE PACIFIC NORTHWEST ELECTRIC POWER PLANNING AND CONSERVATION ACT. ASSUMING NO NIGHTTIME RETURN CONSTRAINTS
ASURTHE ELETRIC POWER PLANNTNG AND

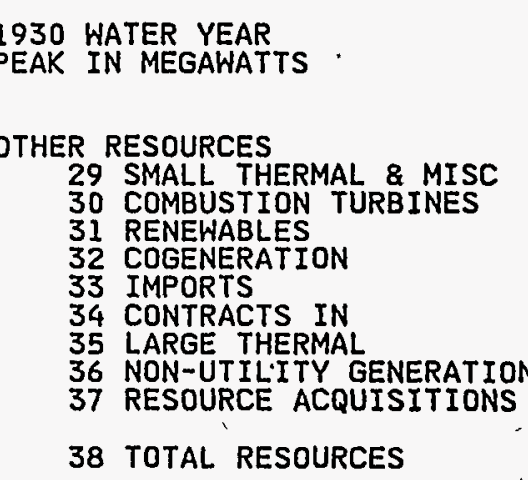


SUMMARY OF FEDERAL SYSTEM LOADS AND RESOURCES IN THE PACIFIC NORTHWEST REGION UNDER THE PACIFIC NORTHWEST ELECTRIC POWER PLANNING AND CONSERVATION ACT ASSUMING NO NIGHTTIME RETURN CONSTRAINTS

MEDIUM LOADS

1999- O OPERATING YEAR'

1994 WHITEBOOK: $12 / 20 / 94$ RUN DATE: $\quad 12 / 20 / 94$

1930 WATER YEAR
PEAK IN MEGAWATTS

AUG
$1-15 \quad$ AUG
$16-31$

SEP. OCT NOV DEC JAN

FEB MAR APR APR MAY JUN JUL

LOADS

1. FEDERAL AGENCIES

2 FEDERAL \& GEN PUBLIC LOSSES

DSI ALUMINUM FIRM

DSI ALUMINUM FIRM

6 DSI FIRM LOSSES

8 FIRM SYSTEM LOAD

\begin{tabular}{|c|c|c|c|c|c|c|c|c|c|c|c|c|c|}
\hline $\begin{array}{l}202 \\
199 \\
970 \\
216 \\
63\end{array}$ & $\begin{array}{r}196 \\
202 \\
199 \\
1970 \\
216 \\
63 \\
4332\end{array}$ & $\begin{array}{r}186 \\
235 \\
157 \\
1971 \\
214 \\
65 \\
4361\end{array}$ & $\begin{array}{r}197 \\
305 \\
76 \\
1970 \\
212 \\
70 \\
4962\end{array}$ & $\begin{array}{r}205 \\
352 \\
77 \\
1971 \\
210 \\
76\end{array}$ & $\begin{array}{r}235 \\
393 \\
4 \\
1971 \\
182 \\
79 \\
5857\end{array}$ & $\begin{array}{r}219 \\
403 \\
4 \\
1971 \\
188 \\
84\end{array}$ & $36 \frac{1}{3}$ & $\frac{2}{3}$ & 2 & $\begin{array}{r}2 \\
19 \\
2 \\
53\end{array}$ & & 45 & \\
\hline & & 10 & & & & & & & & & & & \\
\hline
\end{tabular}

TRANSFERS OUT

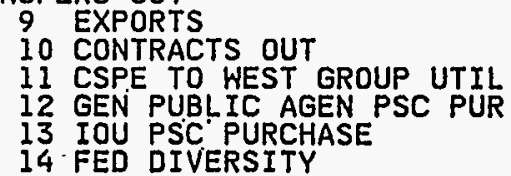

DIVERSITY

15 FIRM LOADS

INTERRUPTIBLE LOADS

16 DSI ALUM TOP QUARTILE

17 DSI NON-ALUMINUM TQ

19 TOTAL LOADS

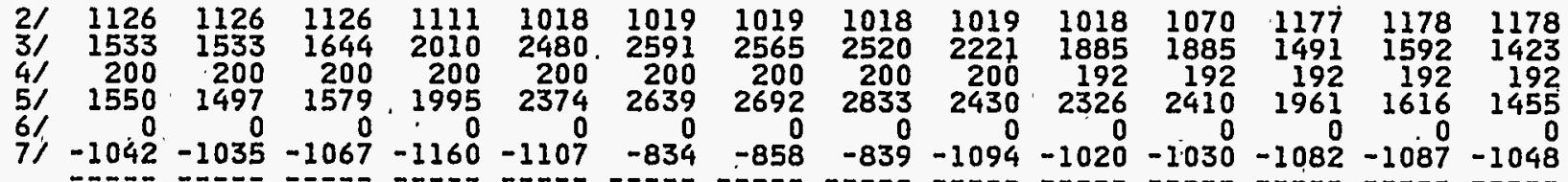

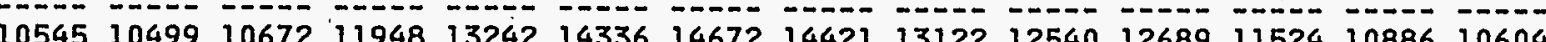

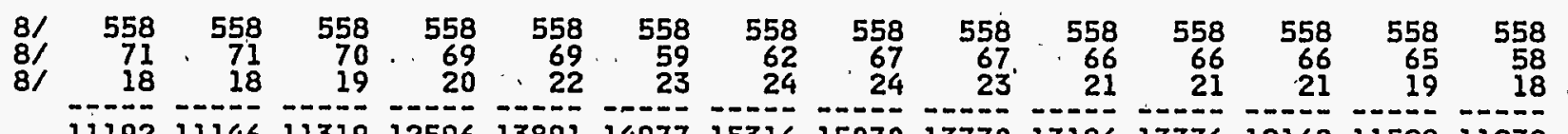

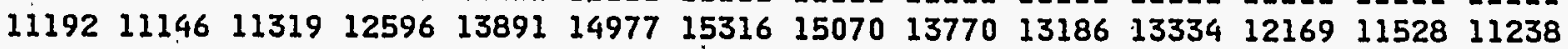

2026920494205242058120945209152088420844206682004619713194651967319636

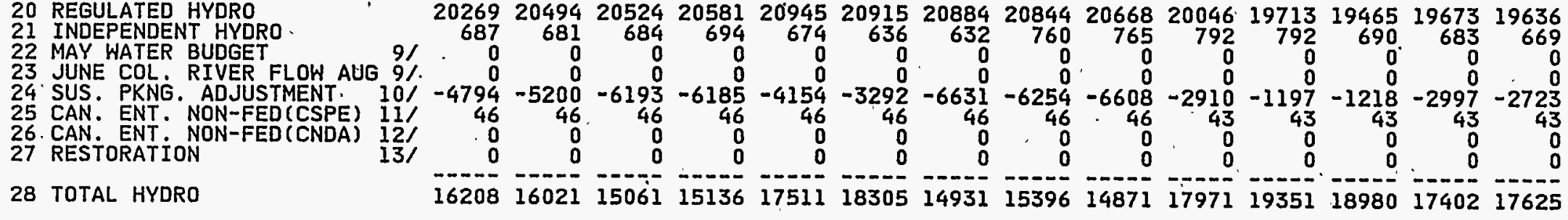

20 REGULATED HYDRO

22 MAY WATER BUDGET

23 JUNE COL. RIVER FLOW A

25 CAN. ENT. NON-FED(CSPE)

28 TOTAL HYDRO

$\begin{array}{llllllllllllll}16208 & 16021 & 15061 & 15136 & 17511 & 18305 & 14931 & 15396 & 14871 & 17971 & 19351 & 18980 & 17402 & 17625\end{array}$ 
SUMMARY OF FEDERAL SYSTEM LOADS AWO RESOURCES IN THE PACIFIC NORTHWEST REGTON UNDER THE PACIFIC NORTHWEST ELECTRIC POWER PLANNING AND CONSERVATION ACT ASSUMING NO NIGHTTIME RETURN CONSTRAINTS

\section{$M E D I U M \quad L O A D S$}

1999- 0 OPERATING YEAR

1994 WHITEBOOK: $12 / 20 / 94$

1930 WATER YEAR

PEAK IN MEGAWATTS

OTHER RESOURCES

29 SMALL THERMAL \& MISC

COMBUSTION TURBINES

31 RENEWABLES

33 IMPORTS

34 CONTRACTS IN

35 LARGE THERMAL

37 RESOURCE ACQUISITIONS

38 TOTAL RESOURCES

RUN DATE: $\quad 12 / 20 / 94$

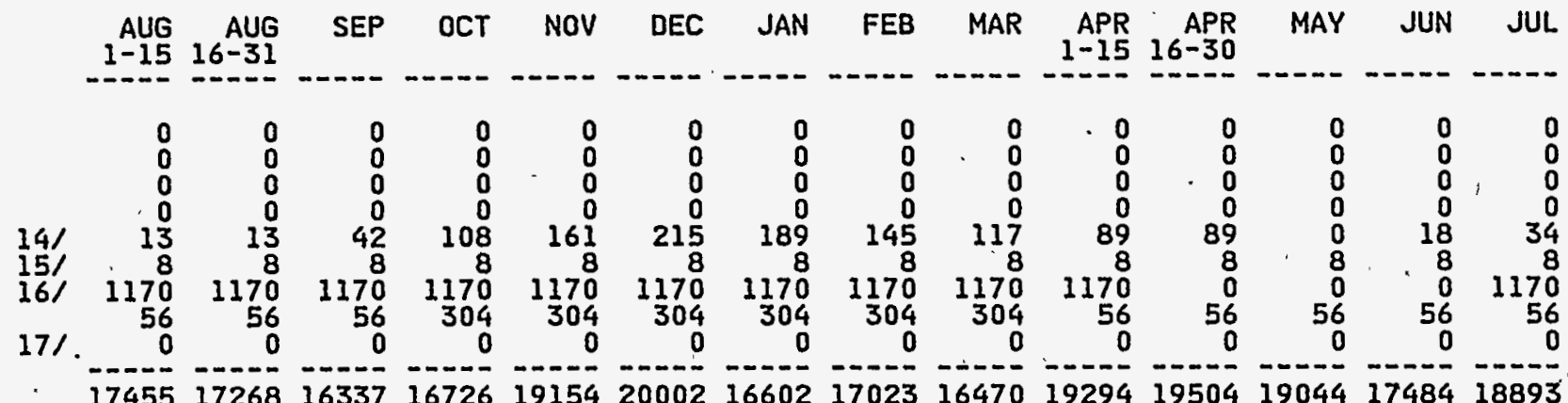

RESERVES AND MATNTENANCE

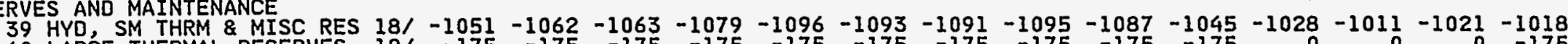

40 LARGE THERMAL RESERVES

41 SPINNING RESERVES

42 DSI RESERVES

44 NET RESOURCES

SURPLUS/DEFICITS

45 FIRM SURPLUS/DEFICIT

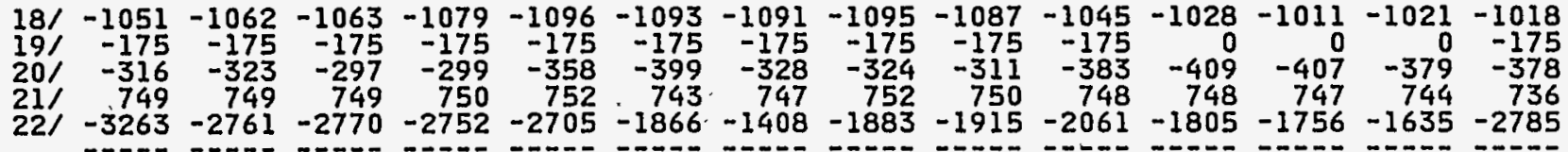

$\begin{array}{llllllllllllll}13399 & 13696 & 12782 & 13171 & 15571 & 17213 & 14347 & 14298 & 13733 & 16378 & 17010 & 16616 & 15194 & 15273\end{array}$

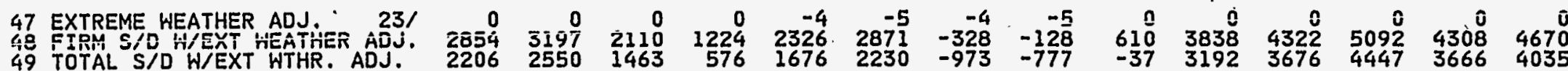

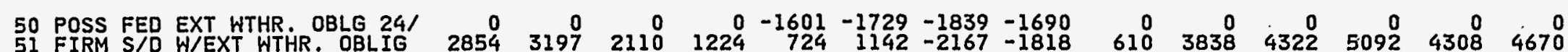

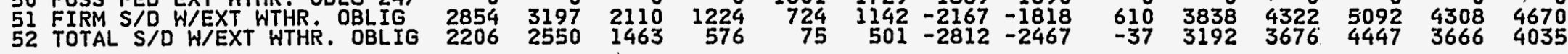

NOTE: 1. BPA SURPLUS POWER SALES CONTRACTS WITH THE PSW ARE SHOWN AS POWER SALES UNTIL THEY EXPIRE.

2. BPA SURPLUS POWER SALES CONTRACT WITH PSP\&L IS SHOWN AS A POWER SALE THROUGH JUNE $30,2001$.

THE CONTRACT THEN CONVERTS TO A SEASONAL POWER EXCHANGE WHICH EXPIRES JULY $1,2008$.

a)

3. THE FOLLOWING BPA CONTRACTS ARE RESOURCE OPTIONS AND NOT INCLUDED IN THIS ANALYSIS.

A. BGP TO BPA, SUPPLEMENTAL ENERGY

B. SCE TO BPA, SUPPLEMENTAL ENERGY

C; SCE TO BPA, OPTION ENERGY 
i) TABLE 2: FEDERAL SYSTEM

SUMMARY OF FEDERAL SYSTEM LOADS AND RESOURCES IN THE PACIFIC NORTHWEST REGION UNDER THE PACIFIC NORTHWEST ELECTRIC POWER PLANNING AND CONSERVATION ACT ASSUMING NO NIGHTTIME RETURN CONSTRAINTS

$$
M E D I U M \quad L O A D S
$$

2004- 5 OPERATING YEAR.

1994 WHITEBOOK: $12 / 20 / 94$.

1930 WATER YEAR $\begin{array}{rrrrrrrr}\text { AUG } & \text { AUG } & \text { SEP } & \text { OCT NOV DEC JAN FEB MAR APR APR MAY JUN JUL } \\ 1-15 & 16-31 & & \end{array}$

LOADS

FEDERAL AGENCIES
2 FEDERAL \& GEN PUBLIC LOSSES
3. USBR

4 DSI ALUMINUM FIRM

6 DSI FIRM LOSSES

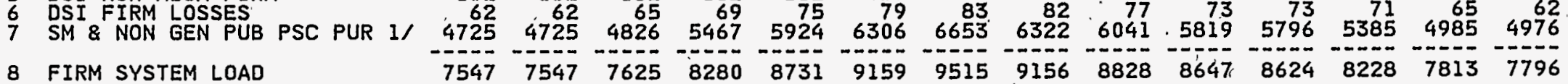

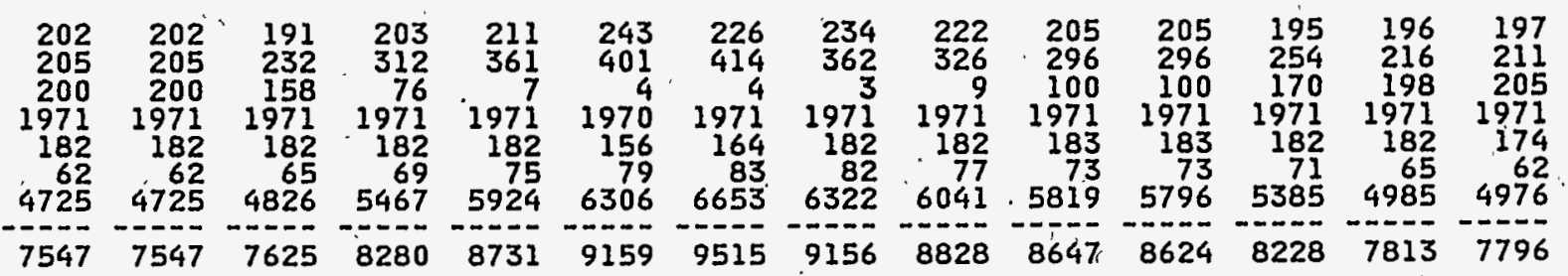

TRANSFERS OUT

9
10
1
1

15 FIRM LOADS

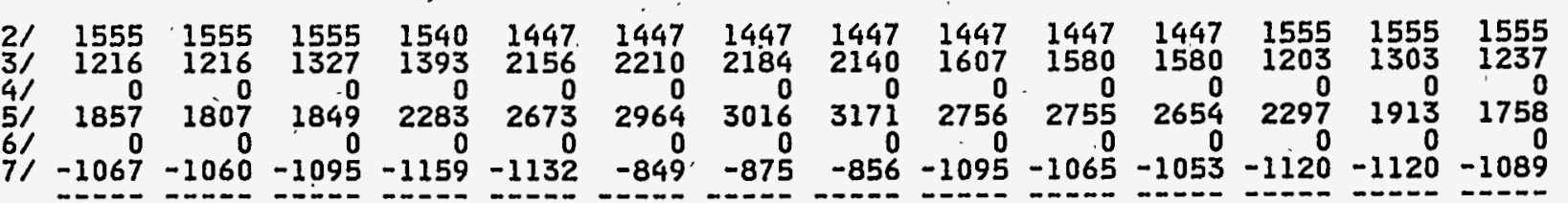
$\begin{array}{llllllllllllll}11109 & 11065 & 11261 & 12338 & 13874 & 14932 & 15288 & 15058 & 13543 & 13363 & 13252 & 12163 & 11465 & 11256\end{array}$

INTERRUPTIBLE LOADS

16 DSI ALUM TOP QUARTILE 18 TOP QUARTILE LOSSES

19 TOTAL LOADS

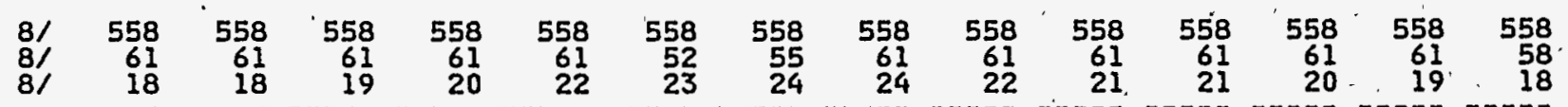
$\begin{array}{lllllllllllllll}1746 & 11702 & 11898 & 12977 & 14515 & 15565 & 15925 & 15701 & 14185 & 14004 & 13892 & 12803 & 12103 & 11891\end{array}$ HYDRO RESOURCES

20 REGULATED HYDRO

21 INDEPENDENT HYDRO

22 MAY HATER BUDGET

23 JUNE COL. RIVER FLOW AUG 9

24 SUS: PKNG. ADJUSTMENT

25 CAN. ENT. NON-FED (CSPE) II/

26 CAN. ENT: NON-FED(CNDA) $12 /$

28 TOTAL HYDRO

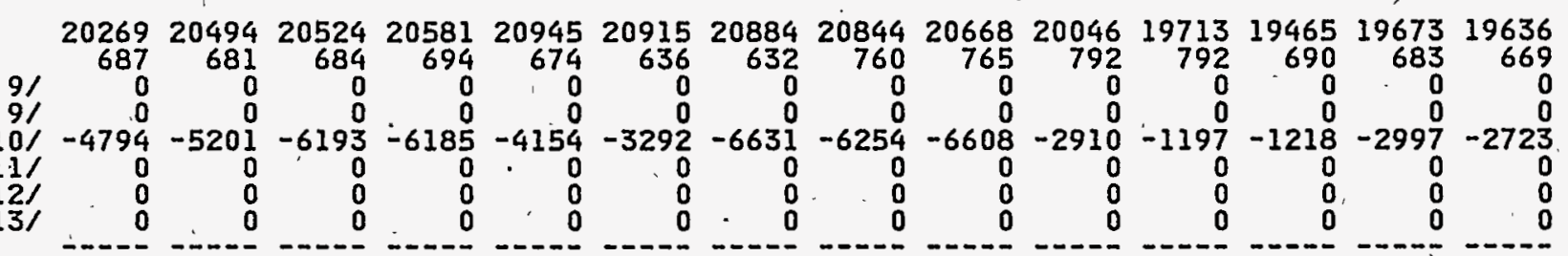

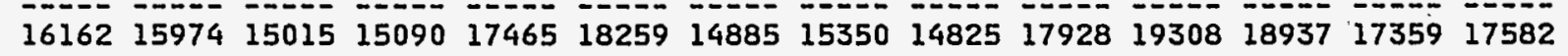


SUMMARY OF FEDERAL SYSTEM LOADS AND RESOURCES IN THE PACIFIC NORTHWEST REGION UNDER THE PACIFIC NORTHWEST ELECTRIC POWER. PLANNING AND CONSERVATION ACT

ME D I U M L OA D S 2004- 5 OPERATING YEAR
1994 WHITEBOOK: $12 / 20 / 94$ RUN DATE: . $12 / 20 \% 94$

330 WATER YEAR

PEAK IN MEGAWATTS

OTHER RESOURCES

29 SMALL THERMAL \& MISC

COMBUSTION TURBINES

31 RENEWABLES

ION

33 IMPORTS

34 CONTRACTS IN

36 NON-UTILITY GENERATION

37 RESOURCE ACQUISITIONS

38 TOTÁL RESOURCES

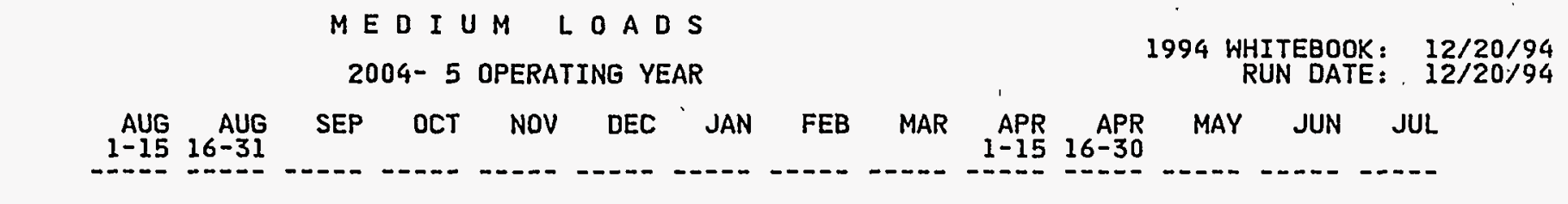

URPLUS/DEFICITS

45 FIRM SURPLUS/DEFICIT

$\begin{array}{llllllllllllll}2533 & 2874 & 1764 & 1078 & 1642 & 2226 & -995 & -815 & 136 & 2965 & 3709 & 4404 & 3680 & 4273 \\ 1896 & 2237 & 1127 & 439 & 1001 & 1593 & -1632 & -1457 & -505 & 2325 & 3069 & 3764 & 3043 & 3639\end{array}$

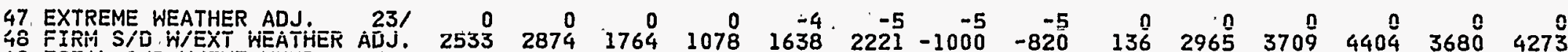
$\begin{array}{llllllllllllllll}40 \text { FIRHA SID WHEXT WEA THEF ADJj. } & 2533 & 2874 & 1764 & 1078 & 1638 & 2221 & -1000 & -820 & 136 & 2965 & 3709 & 4404 & 3680 & 4273 \\ 49 \text { TOTAL S/D W/EXT WTHR. ADJ. } & 1896 & 2237 & 1127 & 439 & 997 & 1588 & -1637 & -1462 & -505 & 2325 & 3069 & 3764 & 3043 & 3639\end{array}$

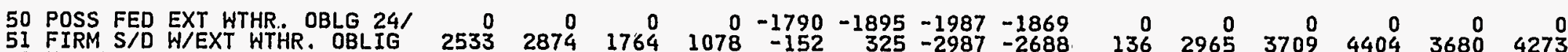

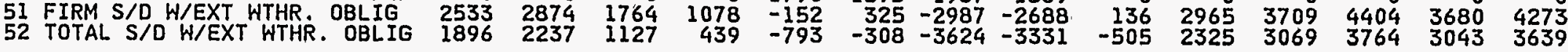

NOTE: 1. BPA SURPLUS POHER SALES CONTRACTS WITH THE PSW ARE SHOWN AS POWER SALES UNTIL THEY EXPIRE.

2. BPA SURPLUS POWER SALES CONTRACT WITH PSPEL IS SHOWN AS A POWER SALE THROUGH JUNE 30, 2001.

3. THE FOLLOWING BPA CONTRACTS ARE RESOURCE OPTIONS AND NOT INCLUDED IN THIS ANALYSIS.

A. BGP TO BPA, SUPPLEMENTAL ENERGY

B. SCE TO BPA, SUPPLEMENTAL ENERGY 


\section{FEDERAL SYSTEM FOOTNOTES}

\section{For Exhibits 1 through 8}

1. BPA's small and nongenerating public agencies' purchases are requirements these agencies place on BPA under their power sales contracts and BPA's partnership program. BPA's obligation is each agency's net firm load requirement not served by its own dedicated resources.

2. BPA's exports include surplus firm power sales to the cities of Burbank, Glendale, and Pasadena, and to Southern California Edison; BPA's surplus firm power sale to M-S-R Public Power Agency, which converts to a capacity sale on November 1, 2009; BPA's capacity contracts with the cities of Anaheim and Riverside; BPA's capacity for exchange energy with deferred return with the Sacramento Municipal Utility District and San Diego Gas and Electric; BPA's capacity for exchange energy contracts with the cities of Anaheim, Pasadena, and Riverside; BPA's diversity exchange with the city of Riverside; BPA's delivery of environmental storage to Southern California Edison; BPA's contract with BC Hydro for Canadian Entitlement beginning April 1, 1998; and BPA's Northwest-Southwest Intertie losses.

3. BPA's contracts out include its contracts of Canadian Entitlement capacity and supplemental capacity to Pacific Northwest public agencies and IOUs, which expire March 31, 2003; BPA's contracts with Clark County PUD and other public agencies (Packwood Lake); BPA's WNP-1 obligation contracts with Montana Power Company, Pacific Power and Light, Portland General Electric, Puget Sound Power and Light, and Washington Water Power; BPA's WNP-3 settlement contracts with Pacific Power and Light, Portland General Electric, Puget Sound Power and Light, and Washington Water Power; BPA's power transfer through Pacific Power and Light's system to serve BPA's Southern Idaho load; BPA's capacity sale with Montana Power Company; BPA's surplus firm power sale to Puget Sound Power and Light, which converts to a seasonal power exchange in OY 2001-02; BPA's surplus firm capacity sale to Washington Water Power; BPA's bridge capacity sale to Pacific Power and Light through July 31, 1995; BPA's capacity sale to Portland General Electric; BPA's deferred power exchange with Washington Water Power; and BPA's Baker Head loss replacement with Puget Sound Power and Light.

4. Columbia Storage Power Exchange (CSPE) is the sale of the Canadian share of downstream benefits under the Columbia River Treaty with Canada to a group of Northwest utilities, expiring April 1, 2003.

5. BPA's generating public agencies' purchases are requirements which these agencies place on BPA under their power sales contracts and BPA's partnership program. BPA's obligation is each agency's net firm load requirement not served by its own 
dedicated resources. These contracts actually expire June 30, 2001; however, they are assumed to remain in effect through the 20-year study period.

6. Generating private utility purchase is the contracted peak and energy requirement placed on the Federal system under the IOUs' power sales contracts with BPA Currently, no IOU is placing load on BPA under a power sales contract.

7. Federal diversity is a percentage reduction applied to the Federal system non-coincidental peak utility requirements. This is due to the fact that all peaking electrical loads do not occur simultaneously throughout the region.

8. DSIs' aluminum and nonaluminum top quartile load and associated line losses are BPA's interruptible loads.

9. May Water Budget and June Columbia River Flow Augmentation is the energy loss due to the overgeneration which may be unusable as a firm resource on the Federal system due to the operation of the hydro system.

10. Sustained peaking adjustment is a percentage reduction applied to the Federal hydro system to meet a capacity load of 50 hours per week. This adjustment also includes reductions for Federal hydro maintenance, spinning reserves, forced outage reserves, and summer flow augmentation on the Lower Snake River and John Day hydro projects.

11. Canadian Entitlement Return non-Federal to the Columbia River Storage Exchange (CSPE) reflects the public agencies' and IOUs' obligation of Canadian Entitlement allocation to the Northwest entities of the CSPE, which expires March 31, 2003.

12. Canadian Entitlement Return non-Federal to Canada reflects the Federal system, public agencies', and IOUs' obligation of Canadian Entitlement allocation to Canada, which begins April 1, 1998.

13. Restoration adjusts for the losses and gains of the hydro system due to Canadian storage under the terms of the Pacific Northwest Coordination Agreement. It is an obligation to those utilities that gained generation from the addition of Canadian storage, and a resource gain to utilities that lost generation from Canadian storage.

14. Imports includes exchange energy to BPA from the cities of Anaheim, Pasadena, and Riverside; capacity for energy exchange agreements (\#1 and \#2) with the city of Pasadena; seasonal replacement energy from the city of Riverside; Southern California Edison's return of environmental storage to BPA; exchange energy from the M-S-R Public Power Agency after its surplus firm sale converts to a capacity/energy exchange beginning November 1, 2009; exchange energy returned from San Diego Gas and Electric; deferred energy returned from Sacramento Municipal Utility District, San Diego Gas and Electric, and Washington Water Power; power purchases from Basin Electric Cooperative and TransAlta; power from Pacific Power and Light's Wyoming Division to serve BPA's Southern Idaho load; and BC Hydro's deliveries of power to BPA.

15. Federal contracts in includes exchange energy to BPA from Montana Power Company, energy delivered to BPA by Northern Wasco County PUD from its McNary Fishway project; WNP-3 settlement exchange energy from Pacific Power and Light, Portland General Electric, Puget Sound Power and Light, and Washington 
Water Power; deferred power exchange energy from Washington Water Power; seasonal power exchange energy from Puget Sound Power and Light beginning in OY 2001-02; and power purchases from Puget Sound Power and Light and Montana Power Company.

16. Federal large thermal consists of the generation from WNP-2, operated by WPPSS.

17: Federal NUGs include: Tenaska II (Tenaska at Fredrickson), SDS Lumber (Klickitat Energy), Clearwater Dam (owned by the State of Idaho Department of Water Resources), and Wyoming Wind.

18. Resource acquisitions are resources BPA has identified and contracted for future purchase. When new Federal resource acquisitions are contracted for and/or on line, they will be included in the loads and resources balance.

19. Hydro, small thermal and miscellaneous resources, and combustion turbine reserve requirements are estimated at 5 percent of the Federal capacity of these resources.

20. Large thermal reserve requirements are estimated at 15 percent of the WNP-2 nuclear project.

21. Federal spinning reserve is the reserve generating capacity maintained to provide a regulating margin for the automatic generation and frequency control of power generation.

22. Direct service industrial reserve requirements are one-third of the industrial firm load, or the sum of the reserve requirements for Federal hydro, small thermal and miscellaneous resources, combustion turbines, and large thermal resources, whichever is smaller.

23. Hydro maintenance is the sum of all Federal hydro project maintenance based on the mean of the 1983-84 through 1988-89 schedules submitted to the Northwest Power Pool.

24. Extreme weather adjustmient for BPA's directly served loads.

25. Possible Federal extreme weather adjustment is the possible load on BPA by public agencies customers having the right to place this obligation on BPA. 
SECTION VIII

\section{PACIFIC NORTHWEST REGIONAL EXHIBITS}




\section{THIS PAGE INTENTIONALLY LEFT BLANK}




\section{EXHIBIT 9 \\ REGIONAL CRITICAL PERIOD ANALYSIS \\ ENERGY FOR 10 OPERATING YEARS}


SUMMARY OF PACIFIC NORTHWEST REGIONAL LOADS AND RESOURCES

UNDER THE PACIFIC NORTHWEST ELECTRIC POWER PLANNING AND CONSERVATION ACT

ME I U M 'L O A D S

OPERATING YEAR

MEGAWATTS

FIRM LOADS

1 SYSTEM FIRM: LOADS

3 FEDERAL DIVERSITY

: 4 FIRM LOADS

INTERRUPTIBLE LOADS

5 REGIONAL INTER. LOADS

6 TOTAL LOADS

HYDRO RESOURCES

7 REGULATED HYDRO

8 INDEPENDENT HYDRO

9 MAY WATER BUDGET

10 JUNE COL. RIVER FLOW AUG

SUS. PKNG. ADJUSTMENT

12 TOTAL HYDRO

OTHER RESOURCES

13 SMALL THERMAL \& MISC

14 COMBUSTION TURBINES

15 RENEWABLES

17 IMPORTS

18 CENTRALIA

19 JIM BRIDGER
20 COLSTRIP I \& 2

21 BOARDMAN

23 COLSTRIP 3

24 WNP

25 COLSTRIP 4

26 FED RESOURCE ACQUIS

27. NON-UTILITY GENERATION

28 TOTAL RESOURCES

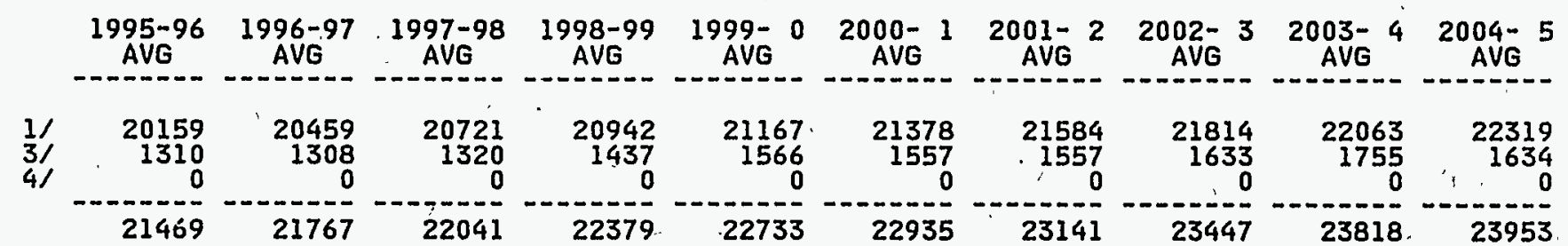

21

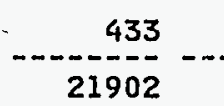

\begin{abstract}
638
\end{abstract}

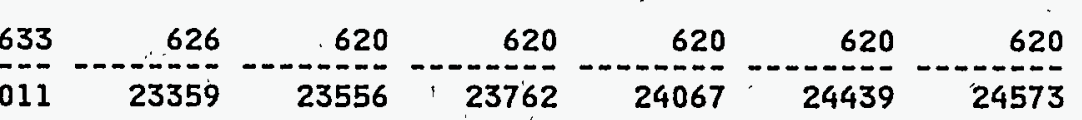

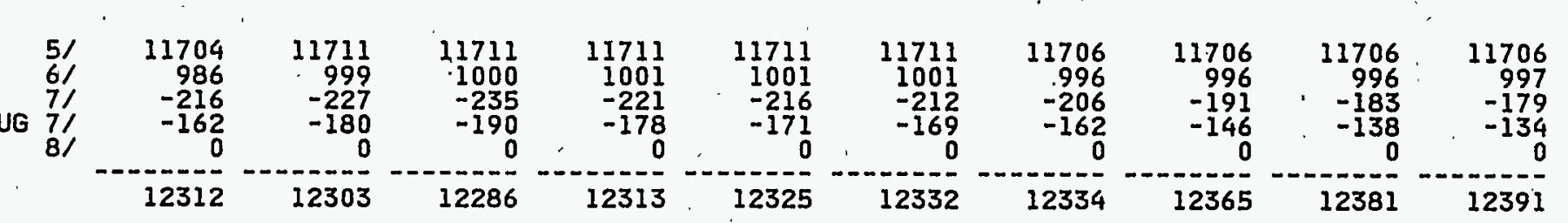


SUMMARY OF PACIFIC NORTHHEST REGIONAL LOADS AND RESOURCES UNDER THE PACIFIC NORTHWEST ELECTRIC POWER PLANNING AND CONSERVATION ACT

MEDIUM LOADS OPERATING YEAR
1994 WHITEBOOK: $12 / 20 / 94$ RUN DATE: $12 / 20 / 94$
MEGAHATTS

RESERVES AND MAINTENANCE

29 HYD SM THRM \& MISC RES 30 LARGE THERMAL RESERVES 31 BPA SPINNING RESERVES 33 HYDRO MAINTENANCE 34 NET RESOURCES

SURPLUS/DEFICITS 35 FIRM SURPLUS/DEFICIT
36 TOTAL- SURPLUS/DEFICIT

37 EXTREME WEATHER ADJ.

38 FIRM S/D W/EXT WEATHER $21 /$ 39 TOTAL SID W/EXT WTHR. ADJ.

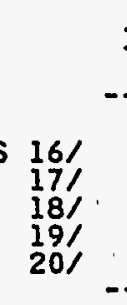
$1995-96$
AVG

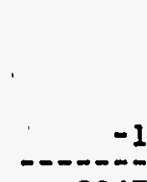

1997-98 1998-99 1999-

2000- 1 2001- $2,2002-3$ 2003- 4 2004- 5 AVG AVG AVG AVG AVG AVG

$2002-3$
AVG
AVG
AVG

$\begin{array}{r}0 \\ 0 \\ 0 \\ 0 \\ -11 \\ \hdashline 20839\end{array}$

20635

-834
-1268

-928
-1566

0

-834
-1268
0
-928

-928
-1566
0
0
0
0
-11

$21001 \quad 20980$

-1399
-2031

$-1678$

$\begin{array}{rr}0 & 0 \\ 0 & 0 \\ 0 & 0 \\ 0 & 0 \\ -11 & -11\end{array}$

0
0
0
0
-11

20962

21002

$\cdot \begin{aligned} & 0 \\ & 0 \\ & 0 \\ & 0 \\ & -31\end{aligned}$

$-12$

-1770
-2396

-1933
-2554

-2290
-2910

$-1040^{\circ}$
$-1678^{-}$

0
-1399
-2031

$-1770^{\circ}$
-2396

-1933
-2554

-2290
-2910

\begin{tabular}{rrr}
0 & 0 & 0 \\
0 & 0 & 0 \\
0 & 0 & 0 \\
0 & 0 & 0 \\
-11 & -11 & -11 \\
\hline 20874 & 20919 & 20836 \\
-2573 & -2899 & -3117 \\
-3193 & -3520 & -3737 \\
0 & 0 & 0 \\
-2573 & -2899 & -3117 \\
-3193 & -3520 & -3737
\end{tabular}




\section{THIS PAGE' INTENTIONALLY LEFT BLANK}




\section{EXHIBITS $10-12$}

REGIONAL MONTHLY ANALYSIS UNDER MEDIUM

LOADS FOR 1930 WATER CONDITIONS 
UNDER THE PACIFIC NORTHWEST ELECTRIC POWER PLANNING AND CONSERVATION ACT

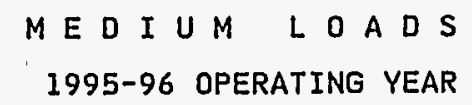

1995-96 OPERATING YEAR 1994 WHITEBOOK: $12 / 20 / 94$
RUN DATE: $12 / 20 / 94$

1930 WATER YEAR
ENERGY IN AVERAGE MEGAWATTS

RUN DATE: $12 / 20 / 94$

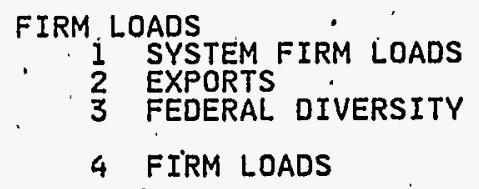

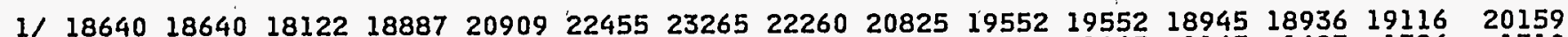

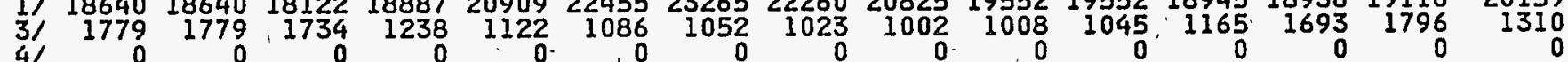

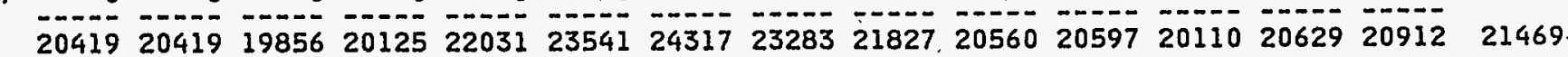

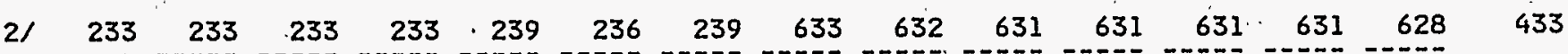
206522065220089203582226923777245562391722459211922122920741212592154021902

HYDRO RESOURCES

7 REGULATED HYDRO

8 INDEPENDENT HYDRO

10. MAY WATER BUDGET

10 JUNE COLL. RIVER FLOW AUG 12 TOTAL HYDRO

5/ $9782 \quad 9934,9375,95981111512039 \quad 11022 \cdot 1101910511 \quad 1188416984158861406311659 \quad 11715$

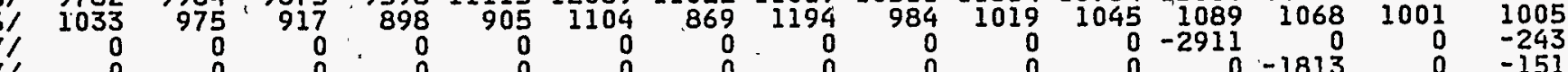

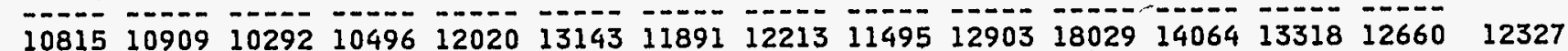
OTHER RESOURCES

13 SMALL THERMAL \& MISC 14 COMBUSTION TURBINES 15 RENEWABLES

16 COGENERA

18 CENTRALIA

19 JIM BRIDGER

20 COLSTRIP 1 \& 2

21 BOARDMAN

23 COLSTRIP 3

25 COLSTRIP 4

27 NON-UTILITY GENERATION 15/

$\begin{array}{rrr}71 & 71 & 70 \\ 543 & 543 & 543 \\ 47 & 47 & 47 \\ 51 & 51 & 267 \\ 1829 & 1829 & 1573 \\ 1295 & 1295 & 1295 \\ 635 & 635 & 635 \\ 358 & 358 & 356 \\ 426 & 426 & 426 \\ 202 & 202 & 202 \\ 528 & 528 & 527 \\ 983 & 983 & 983 \\ 657 & 657 & 657\end{array}$

28 TOTAL RESOURCES
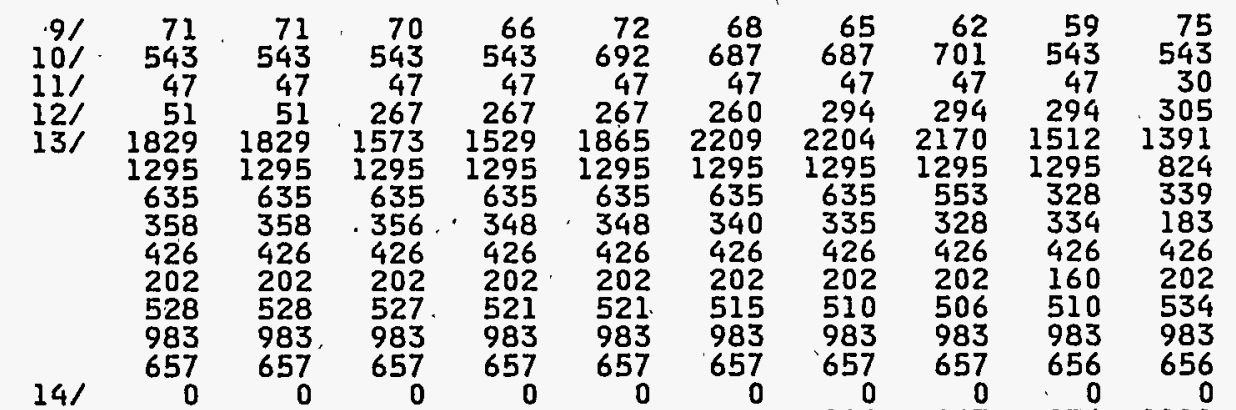

$1136 \quad 1139 \quad 1059$

$954 \quad 920$

002026

947

$\begin{array}{rrr}0 & 0 \\ 974 & 0\end{array}$
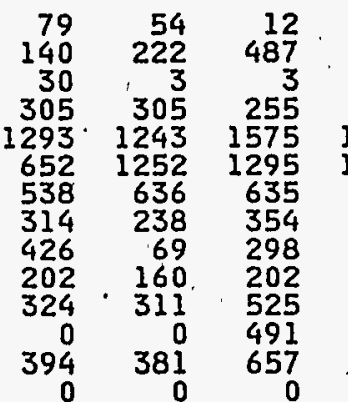

3000

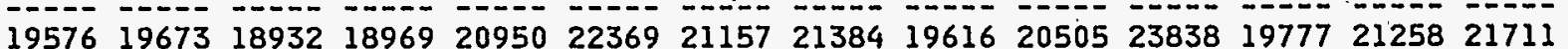

63
544
37
263
1733
1245
586
331
386
195
496
819
623
0
1012

1012 

SUMMARY OF PACIFIC NORTHWEST REGIONAL LOADS AND RESOURCES
UNDER THE PACIFIC NORTHWEST ELECTRIC POWER PLANNING AND CONSERVATION ACT

1930 WATER YEAR MEDI UM. LOADS 1995-96 OPERATING YEAR

1994 WHITEBOOK: $12 / 20 / 94$ ENERGY IN AVERAGE MEGAWATTS

ME D I U M L O A D S
1995-96 OPERATING YEAR
AUG AUG SEP OCT NOV DEC JAN FEB MAR APR APR MAY JUN JUL 12 MO
$1-15$ 16-31

RESERVES AND MAINTENANCE

29 HYD, SM THRM \& MISC RES $16 /$

30 LARGE. THERMAL RESERVES

31 BPA SPINNING

33 HYDRO MAINTENANCE

$\begin{array}{rrrr}16 / & 0 & 0 & 0 \\ 171 & 0 & 0 & 0 \\ 18 / & 0 & 0 & 0 \\ 19 / & 0 & 0 & 0 \\ 20 / & -3 & -25 & -9\end{array}$

\begin{tabular}{rr}
0 & 0 \\
0 & 0 \\
0 & 0 \\
0 & 0 \\
-9 & -9 \\
\hline-9 & -9 \\
\hline
\end{tabular}

\begin{tabular}{rr}
0 & 0 \\
0 & 0 \\
0 & 0 \\
0 & 0 \\
-9 & -4 \\
-9 & -4 \\
\hline
\end{tabular}

\begin{tabular}{rrrrr}
0 & 0 & 0 & 0 & 0 \\
0 & 0 & 0 & 0 & 0 \\
0 & 0 & 0 & 0 & 0 \\
0 & 0 & 0 & 0 & 0 \\
0 & 0 & 0 & -5 & -7 \\
\hline
\end{tabular}

34 NET RESOURCES

$\begin{array}{lllllllll}19545 & 19648 & 18923 & 18960 & 20946 & 22369 & 21157 & 21384 & 1961\end{array}$

SURPLUS/DEFICITS

35 FIRM SURPLUS/DEFICIT

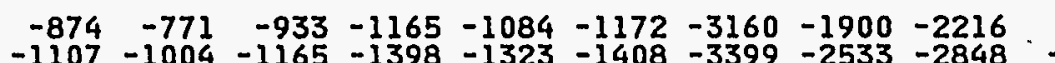

37 EXTREME WEATHER ADJ. 21 . $\begin{array}{lllllllll}-1107 & -1004 & -1165 & -1398 & -1323 & -1408 & -3399 & -2533 & -2848\end{array}$

0497

$$
\begin{array}{rrrr}
0 & 0 & 0 & 0 \\
0 & 0 & 0 & 0 \\
0 & 0 & 0 & 0 \\
0 & 0 & 0 & 0 \\
-8 & -20 & -15 & -50
\end{array}
$$

0
0
0
0
-12

39 TOTAL S/D W/EXT WTHR. ADJ.

$\begin{array}{rrrrrrrrr}0 & 0 & 0 & 0 & 0 & 0 & 0 & 0 & 0 \\ -874 & -771 & -933 & -1165 & -1084 & -1172 & -3160 & -1900 & -2216\end{array}$

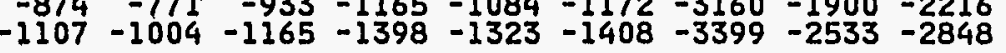

$\begin{array}{rr}-63 & 3233 \\ -694 & 2602\end{array}$

197572124321661

20648 
UNDER THE PACIFIC NORTHWEST ELECTRIC POWER PLANNING AND CONSERVATION ACT

\section{MEDIUM LOADS}

1999- O OPERATING YEAR

1930 WATER YEAR
ENERGY IN AVERAGE MEGAWATTS

FIRM LOADS

1 SYSTEM FIRM LOADS

3 EXPORTS DIVERSITY

4 .FIRM LOADS

INTERRUPTIBLE LOADS

5 REGIONAL INTER. LOADS

6 TOTAL LOADS

HYDRO RESOURCES

7 REGULATED HYDRO

8 INDEPENDENT HYDRO

Io JUNE COL. RIVER FLOW AU

10 JUNE COL. RIVER FLON

12 TOTAL HYDRO

OTHER RESOURCES

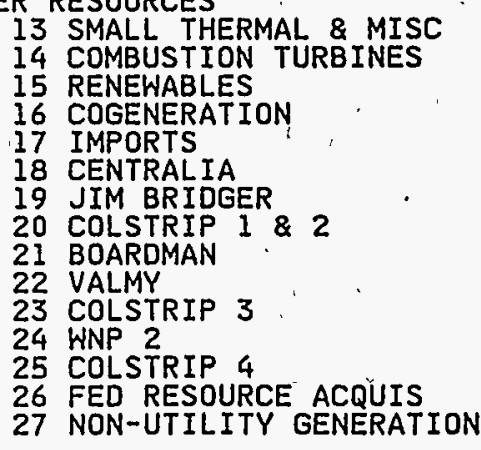

28 TOTAL RESOURCES

AUG AUG SEP OCT NOV DEC JAN FEB MAR APR APR MAY JUN JUL 12 MO
$1-15$
$16-31$

$1 / 197261972619196199152195723539242932328321798 \quad 204852048519866198772006621167$

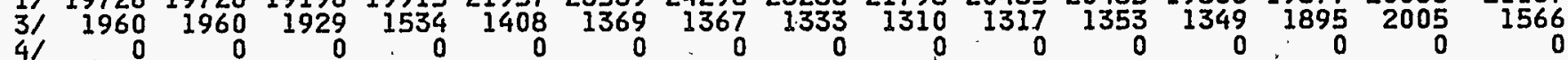

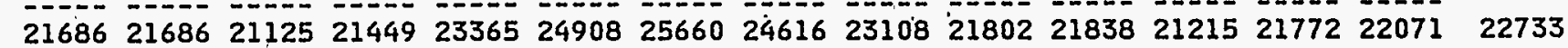

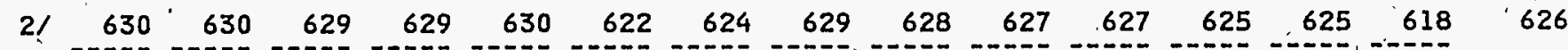

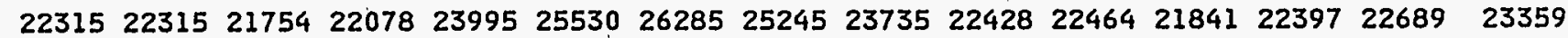

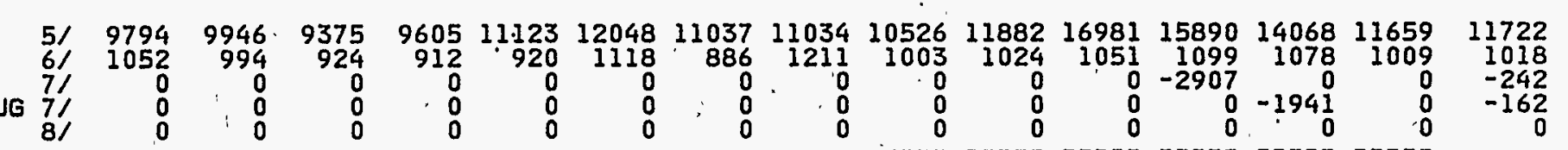
$\begin{array}{lllllllllllllll}10846 & 10940 & 10299 & 10517 & 12043 & 13166 & 11923 & 12245 & 11529 & 12906 & 18032 & 14082 & 13205 & 12668 & 12337\end{array}$

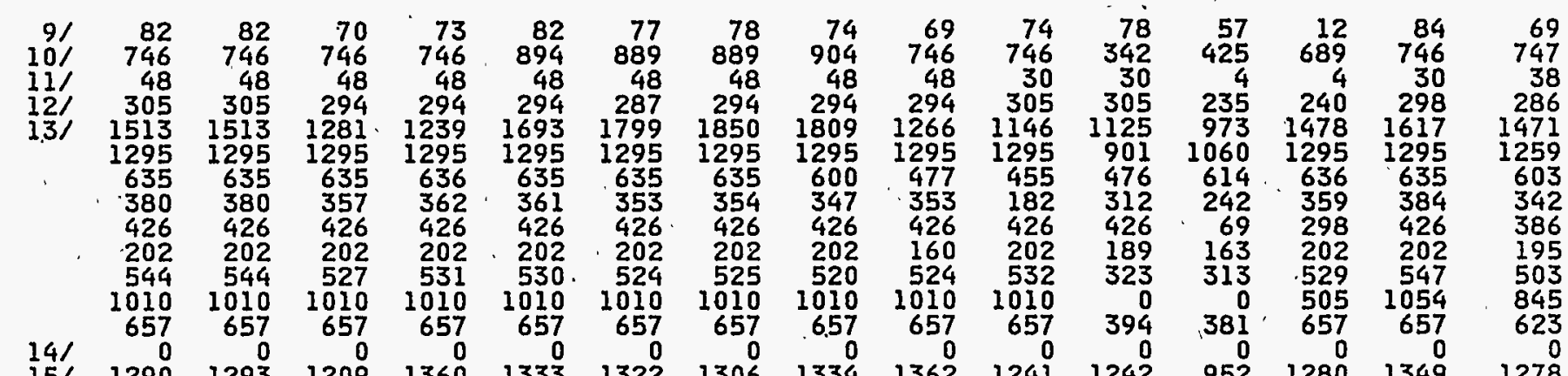

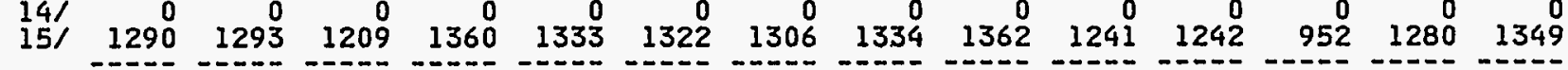
1997920076190561939621503226902149221765202162120724175195692138921992 
TABLE I: PACIFIC NORTHWEST REGIONAL AREA

SUMMARY OF PACIFIC NORTHWEST REGIONAL LOADS AND RESOURCES UNDER THE PACIFIC NORTHWEST ELECTRIC POWER PLANNING AND CONSERVATION ACT

$$
\text { MEOIUM LOADS }
$$

1999- O OPERATING YEAR

1994 WHITEBOOK: $\quad 12 / 20 / 94$

1930 WATER YEAR

ENERGY IN AVERAGE MEGAWATTS

$\underset{1-15}{\text { AUG }} \underset{16-31}{\text { AUG }}$

RESERVES AND MAINTENANCE

29 HYD, SM THRM \& MISC RES 16/

30 LARGE THERMAL RESERVES 17

31 BPA SPINNING RESERVES

33 HYDRO MAINTENANCE

$18 \%$
$190 \%$

34 NET RESOURCES

SURPLUS/DEFICITS

35 FIRM SURPLUS/DEFICIT

36 TOTAL SURPLUS/DEFICIT

$\begin{array}{rrrrr}-31 & -26 & -0 & 0 & 0 \\ -31 & -9 & -4\end{array}$

-1096 (20051

DEC JAN FEB MAR APR
$1-15$ APR
$16-30$ MAY JUN JUL 12 MO

37 EXTREME WEATHER ADJ. 21 .

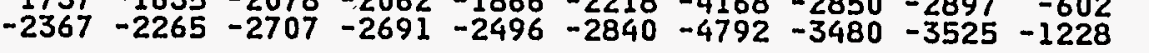

$\begin{array}{llll}-1666 & -398 & -129 & -1763\end{array}$

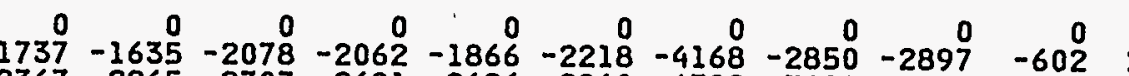

39. TOTAL S/D W/EXT WTHR. ADJ.

$\begin{array}{llllllllll}-1737 & -1635 & -2078 & -2062 & -1866 & -2218 & -4168 & -2850 & -2897 & -602 \\ -2367 & -2265 & -2707 & -2691 & -2496 & -2840 & -4792 & -3480 & -3525 & -1228\end{array}$

\begin{tabular}{rrrrr}
0 & 0 & 0 & 0 & 0 \\
\hline & $-1666^{2}$ & $-398^{2}$ & $-129^{\circ}$ & $-176^{3}$
\end{tabular}

$\begin{array}{lllll}1704 & -2291 & -1023 & -747 & -2389\end{array}$ 
SUMMARY OF PACIFIC NORTHWEST REGIONAL LOADS AND RESOURCES

UNDER THE PACIFIC NORTHWEST ELECTRIC POWER PLANNING AND CONSERVATION ACT

MEDIUM L OADS

1930 HATER YEAR

ENERGY IN AVERAGE MEGAWATTS

FIRM LOADS

1 SYSTEM FIRM LOADS

2 EXPORTS

4 FIRM LOADS

INTERRUPTIBLE LOADS

5 REGIONAL INTER. LOADS

6. TOTAL LOADS

HYDRO RESOURCES

7 REGULATED HYDRO

8 INDEPENDENT HYDRO

I0 JUNE COL. RIVER FLOW AUG

II SUS. PKNG. ADJUSTMENT

12 TOTAL HYDRO

OTHER RESOUREES

13 SMALL THERMAL \& MISC

14 COMBUSTION TURBINES

15 RENEWABLES

16 COGENERATION

17 IMPNTRA

18 CENTRALIA

20 COLSTRIP 1 \&

20 COLSTRIP 1 \&

21 BOARDMAN

23 COLSTRIP 3

23 COLSTRI

25 COLSTRIP 4

26 FED RESOURCE ACOUIS

27 NON-UTILITY GENERATION

28 TOTAL RESOURCES
2004- 5 OPERATING YEAR

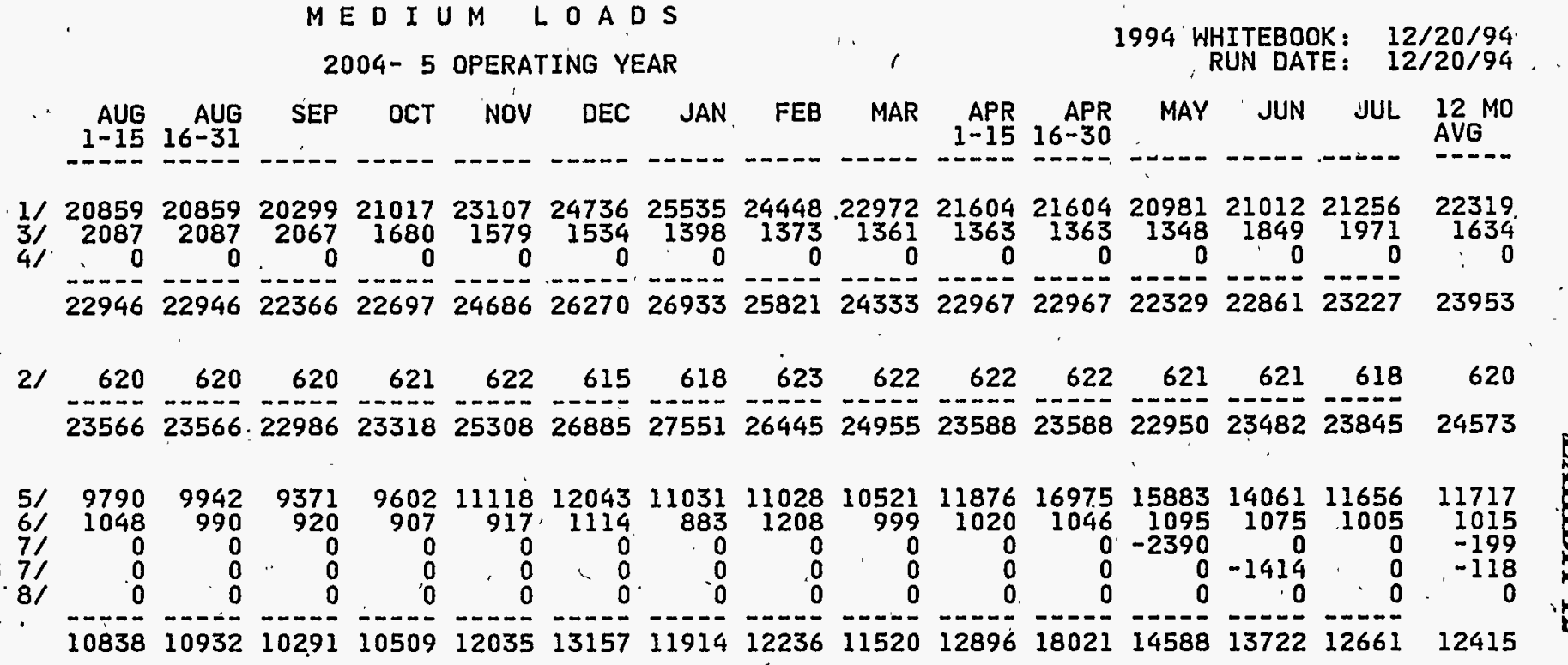

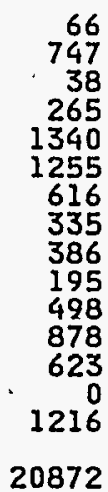


SUMMARY OF PACIFIC NORTHWEST REGIONAL LOADS AND RESOURCES
UNDER THE PACIFIC NORTHWEST ELECTRIC POWER PLANNING AND CONSERVATION ACT

ME DIUM LOADS

2004- 5 OPERATING YEAR
1994 WHITEBOOK $12 / 20 / 94$ RUN DATE: $12 / 20 / 94$

1930 WATER YEAR
ENERGY IN AVERAGE MEGAWATTS

$\underset{1-15}{A-16-31}$

FEB MAR

$\underset{1-15}{A P R} \quad \begin{array}{r}\text { APR } \\ 16-30\end{array}$

MAY JUN JUL 12 MO

RESERVES AND MAINTENANCE

29 HYD, SM THRM \& MISC RES $16 /$

30 LARGE THERMAL RESERVES 17

31 BPA SPINNING RESERVES

32 DSI RESERVE

33 HYDRO MAINTENANCE

34 NET RESOURCES

171
$18 /$
$19 \%$
$20 \%$

$\begin{array}{r}0 \\ 0 \\ 0 \\ -31 \\ \hline\end{array}$

0
0
0
0
-26
-26

$\begin{array}{rr}0 & 0 \\ 0 & 0 \\ 0 & 0 \\ 0 & 0 \\ 9 & -4\end{array}$

$\begin{array}{r}0 \\ 0 \\ 0 \\ 0 \\ 0 \\ \hdashline\end{array}$

JAN

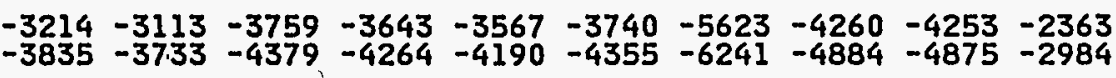

35 FIRM SURPLUS/DEFICIT
36 TOTAL SURPLUS/DEFICIT

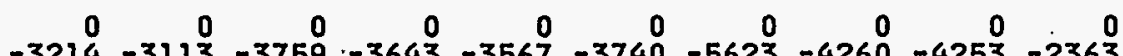

37 EXTREME WEATHER ADJ. 21 .

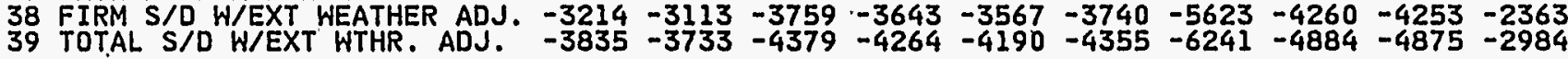

$$
\begin{array}{rr}
0 & 0 \\
0 & 0 \\
0 & 0 \\
0 & 0 \\
-7 & -8
\end{array}
$$

$\begin{array}{rrrr}0 & 0 & 0 & 0 \\ 0 & 0 & 0 & 0 \\ 0 & 0 & 0 & 0 \\ 0 & 0 & 0 & 0 \\ -8 & -20 & -15 & -50\end{array}$ AVG

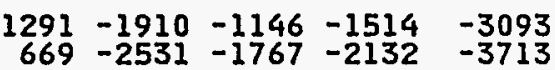

$12900-1910-1146-1514-3093$

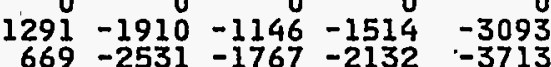




\section{THIS PAGE INTENTIONALLY LEFT BLANK}




\section{EXHIBIT 13 \\ REGIONAL MONTHLY 50-HOUR CAPACITY SURPLUSIDEFICIT UNDER THE FIVE LOAD SCENARIOS FOR 1930 WATER CONDITIONS}


TABLE R-1: 50-HOUR SUSTAINED. PEAKING

BASE CASE: EXISTING REGIONAL CONTRACTS

REGIONAL FIRM 50-HOUR CAPACITY, SURPLUS/DEFICIT

INCLUDING EXTREME WEATHER ADJUSTMENTS DURING NOVEMBER THROUGH FEBRUARY

10 YEAR MONTHLY SUMMARY

ASSUMING NO NIGHTTIME RETURN CONSTRAINTS,
EXISTING REGIONAL CONTRACTS, AND NO NEW RESOURCE ACQUISITIONS

MEDIUM LOADS

1994 WHITEBOOK: $12 / 20 / 94$ RUN DATE: $12 / 20 / 94$

\section{WATER YEAR}

$$
\begin{array}{r}
\text { AUG } \\
1-15 \\
-16-31
\end{array}
$$$$
\text { SEP OCT NOV DEC JAN }
$$$$
\text { FEB MAR }
$$$$
\begin{array}{r}
\text { APR } \\
1-15 \quad \text { APR } \\
16-30
\end{array}
$$

MAY JUN JUL

PEAK IN MEGAWATTS

$\begin{array}{llll}1995-96 & 4585 & 5032 & 448 \\ 1996-97 & 4051 & 4351 & 406 \\ 1997-98 & 4027 & 4473 & 403 \\ 1998-99 & 3759 & 4204 & 340 \\ 1999-00 & 3326 & 3770 & 32 \\ 2000-01 & 3001 & 3446 & 271 \\ 2001-02 & 2820 & 3265 & 24 \\ 2002-03 & 2466 & 2910 & 231 \\ 2003-04 & 1688 & 2133 & 14 \\ 2004-05 & 1540 & 1984 & 117\end{array}$

1421
1790

$\begin{array}{llll}667 & -3302 & -2647 & 1440\end{array}$

$\begin{array}{ll}03 & 1485 \\ 19 & 369\end{array}$

1848

369
$-213-12$

$191-3718$

$479-640-1679$

$226-5119$

$-5523-4345$

$\begin{array}{lll}-5882 & -5289 & -667\end{array}$

$\begin{array}{llll}-2385 & -6300 & -5703 & -1655\end{array}$

$2004-05$

15401984 
EXHIBITS $14-16$ REGIONAL MONTHLY CAPACITY ANALYSIS UNDER MEDIUM LOADS FOR 1930 WATER CONDITIONS 
$\infty$ TABLE 1: PACIFIC NORTHWEST REgIONAL AREA

SUMMARY OF PACIFIC NORTHWEST REGIONAL LOADS AND RESOURCES UNDER THE PACIFIC NORTHWEST ELECTRIC POWER PLANNING AND ASSUMING NO NIGHTTIME. RETURN CONSTRAINTS

MEIDIUM L O A D S

1995-96 OPERATING YEAR 1994 WHITEBOOK: $\quad 12 / 20 / 94$
RUN DATE: $\quad 12 / 20 / 94$

1930 WATER YEAR
PEAK IN MEGAWATTS

FIRM LOADS

1 SYSTEM FIRM LOADS

2 :EXPORTS

4 FIRM LOADS

INTERRUPTIBLE LOADS

5 REGIONAL INTER. LOADS

6. TOTAL LOADS

HYDRO RESOURCES

7 REGULATED HYDRO

8 INDEPENDENT HYDRO

9 MAY WATER BUDGET

10.JUNE COL. RIVER FLOW AUG

12 TOTAL HYDRO

AUG
$1-15$
$16-31$

$1 / 2419524195239422671228956 \quad 311323231931189291152749827498258072501124747$

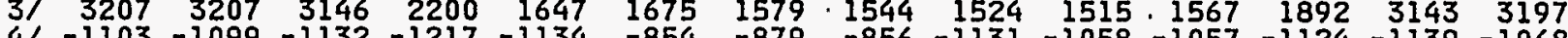

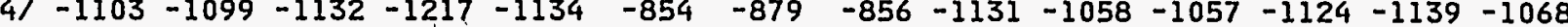

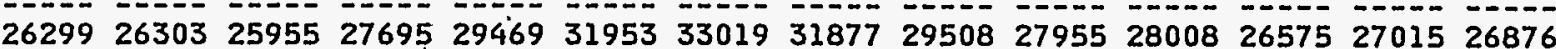

$\begin{array}{lllllllllllllll}21 & 352 & 352 & 345 & 335 & 379 & 309 & 404 & 778 & 806 & 763 & 763 & 768 & 773 & 768\end{array}$

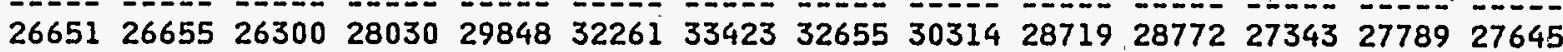
5/.30620 $3097531239313453152831414 \quad 31444 \quad 31138 \quad 31045 \quad 30305 \cdot 30250 \quad 298053020830311$

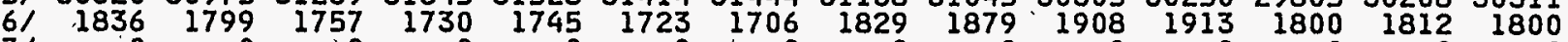

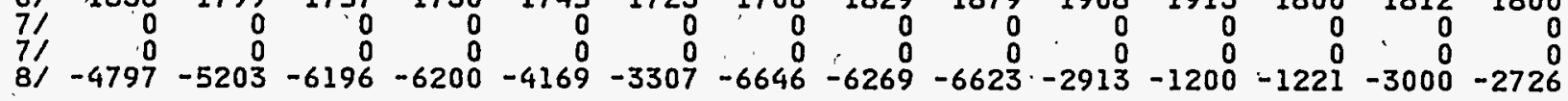

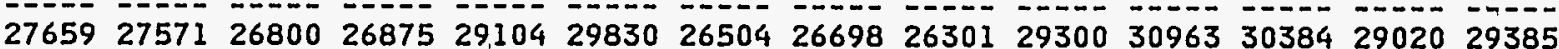

DTHER RESOURCES

13 SMALL THERMAL \& MISC

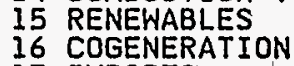

17 IMPORTS

18 CENTRALIA

20 COLSTRIP I \& 2

21 BDARDMAN

22 VALMY

23 COLSTRIP 3

24 WINP 2

25 COLSTRIP

26 FED RESOURCE ACQUIS

27 NON-UTILITY GENERATION 15/

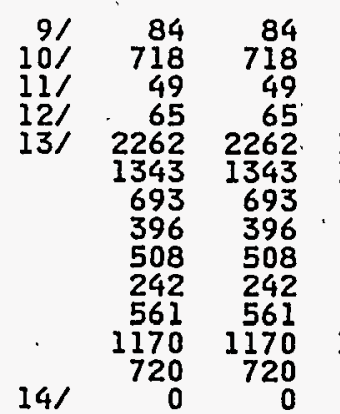

$$
\begin{array}{rrrrrrrr}
72 & 69 & 165 & 162 & 159 & 155 & 65 & 74 \\
718 & 718 & 1416 & 1416 & 1416 & 1416 & 718 & 718 \\
49 & 49 & 49 & 49 & 50 & 50 & 50 & 50 \\
302 & 302 & 302 & 282 & 329 & 329 & 329 & 340 \\
1710 & 1764 & 2116 & 2662 & 2634 & 2652 & 1930 & 1546 \\
1343 & 1343 & 1343 & 1343 & 1343 & 1343 & 1343 & 672 \\
693 & 693 & 692 & 693 & 693 & 520 & 346 & 346 \\
372 & 367 & 376 & 371 & 364 & 357 & 359 & 188 \\
508 & 508 & 508 & 508 & 508 & 508 & 508 & 508 \\
242 & 242 & 242 & 242 & 242 & 242 & 242 & 242 \\
545 & 541 & 548 & 544 & 540 & 535 & 536 & 548 \\
1170 & 1170 & 1170 & 1170 & 1170 & 1170 & 1170 & 1170 \\
720 & 720 & 720 & 720 & 720 & 720 & 720 & 720
\end{array}
$$

28 TOTAL RESOURCES

$378593777136536 \quad 36558 \quad 39904 \quad 41129 \quad 378113785435812 \quad 37768$ 37953 370633774030701 
TABLE $1:$ PACIFIC NORTHWEST REGIONAL AREA

SHEET 2 OF 2

SUMMARY OF PACIFIC NORTHWEST REGIONAL LOADS AND RESOURCES

UNDER THE PACIFIC NORTHWEST ELECTRIC POWER PLANNING AND CONSERVATION ACT ASSUMING NO NIGHTTIME RETURN CONSTRAINTS

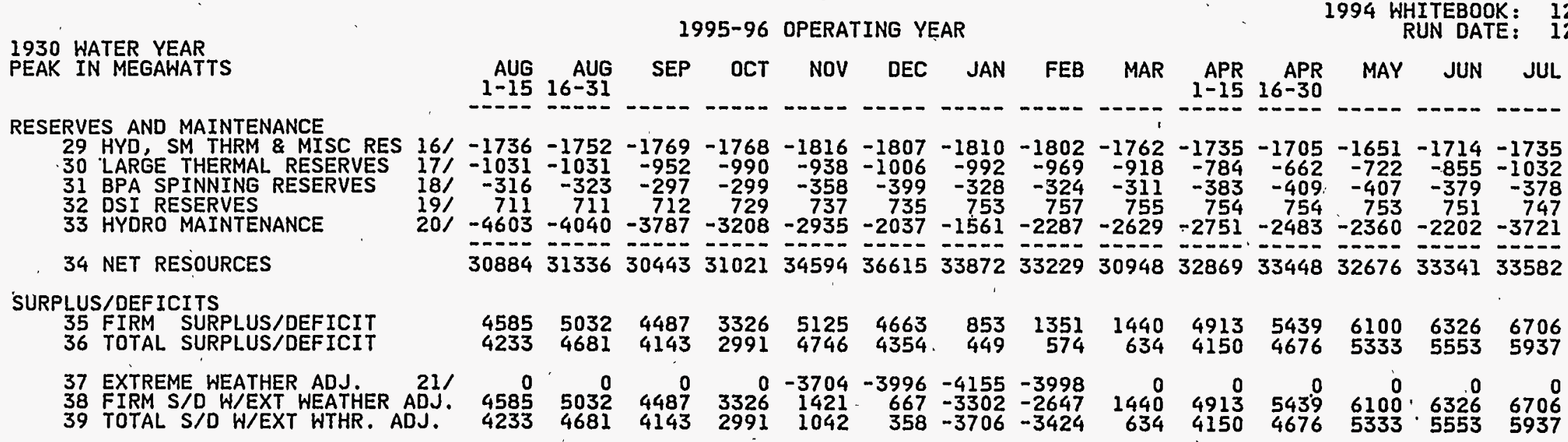

ME D I M L L A D S

1995-96 OPERATING YEAR
1994 WHITEBOOK: $12 / 20 / 94$ $12 / 20 / 94$ 


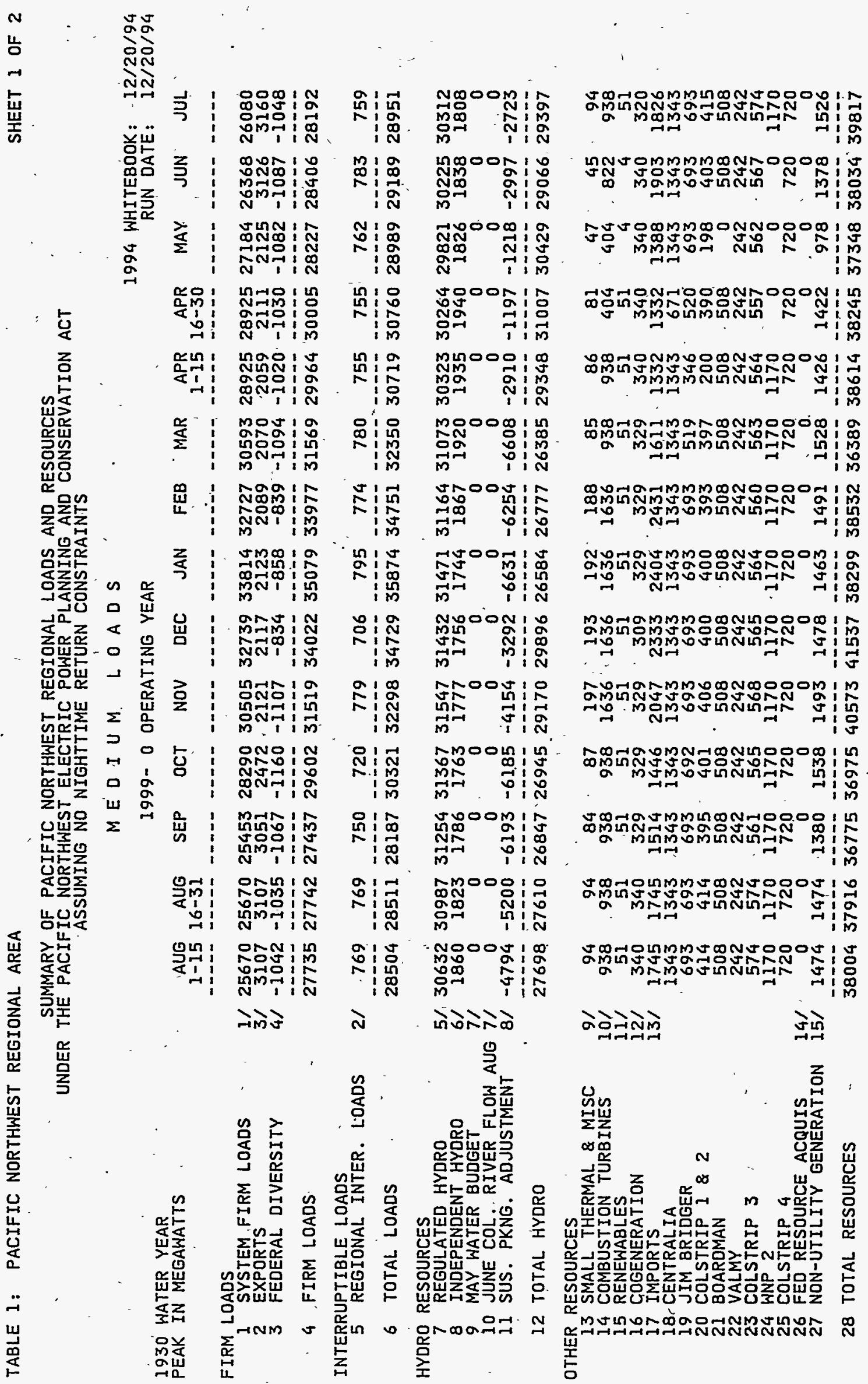


SUMMARY OF PACIFIC NORTHWEST REGIONAL LOADS AND RESOURCES
UNDER THE PACIFIC NORTHWEST ELECTRIC POWER PLANNING AND CONSERVATION ACT ASSUMING NO NIGHTTIME RETURN CONSTRAINTS

1930 WATER YEAR

ME D I M LOADS

PEAK IN MEGAWATTS

1999- O OPERATING YEAR

1994 WHITEBOOK: 12/20/94

RUN DATE: $12 / 20 / 9.4$

RESERVES AND MAINTENANCE

29 HYD, SM THRM \& MISC RES

30 LARGE THERMAL RESERVES

33 . HYDRO MAINTENANCE

SEP OCT NOV DEC JAN

34 NET RESOURCES

SURPLUS/DEFICITS

35 FIRM SURPLUS/DEFICIT

37 EXTREME WEATHER ADJ. $21 /$

38 FIRM S/D W/EXT WEATHER ADJ.

AUG AUG

-...-. -

$16 /$
$17 /$
$18 /$
$19 /$
$20 /$

$\begin{array}{rr}-1767 & -1783 \\ -1004 & -1004\end{array}$

-.-.-.-

$\begin{array}{rr}\text { APR } & \text { APR } \\ 1-15 & 16-30\end{array}$

MAY JUN JUL

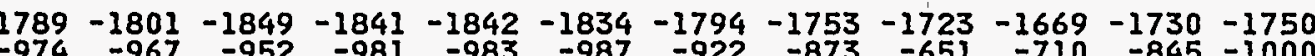

$\begin{array}{llllllllllllll}-316 & -323 & -297 & -299 & -358 & -399 & -328 & -324 & -311 & -383 & -409 & -407 & -379 & -378\end{array}$

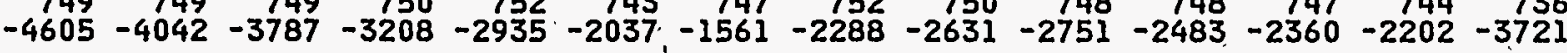

$\begin{array}{llllllllllllllll}31061 & 31513 & 30677 & 31449 & 35231 & 37023 & 34332 & 33851 & 31481 & 33602 & 33727 & 32949 & 33623 & 33704\end{array}$

$\begin{array}{llllllllllllll}3326 & 3770 & 3240 & 1848 & 3712 & 3000 & -747 & -126 & -88 & 3638 & 3722 & 4722 & 5217 & 5512\end{array}$

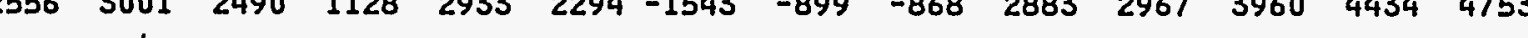

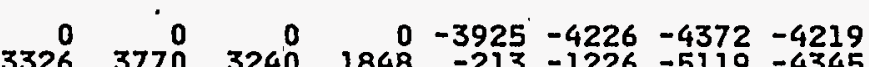

$\begin{array}{llllllll}3326 & 3770 & 3240 & 1848 & -213 & -1226 & -5119 & -4345 \\ 2556 & 3001 & 2490 & 1128 & -992 & -1932 & -5915 & -5118\end{array}$

-88
-868

$3638^{\circ}$

$3722 \quad 4722$

$00^{\circ} \quad 0$

39 TOTAL S/D W/EXT WTHR. ADJ. 
SUMMARY OF 'PACIFIC NORTHWEST REGIONAL LOADS AND RESOURCES UNDER THE PACIFIC NORTHWEST ELECTRIC POWER PLANNING AND CONSERVATION ACT
ASSUMING NO NIGHTIME RETURN CONSTRAINTS

\section{MEDIUM L O A D S}

2004- 5 OPERATING YEAR

1994 WHITEBOOK: $\quad 12 / 20 / 94$

1930 HATER YEAR

FIRM LOADS

1 SYSTEM FIRM LOADS

2 EXPORTS 3 FEDERAL DIVERSITY

4 FIRM LOADS

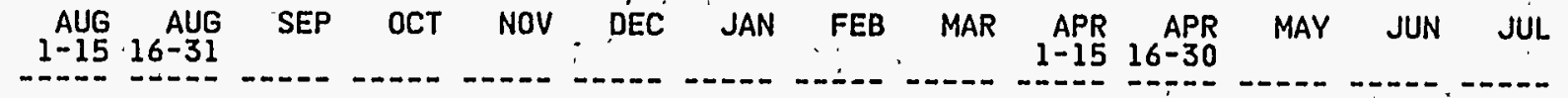

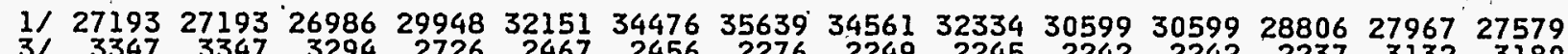

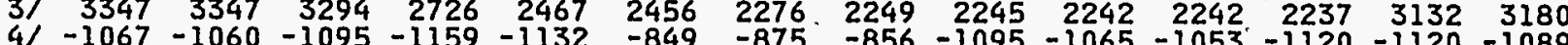

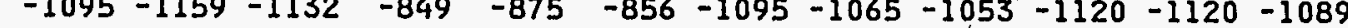

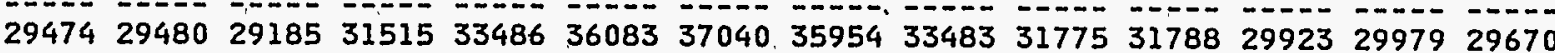

INTERRUPTIBLE LOADS

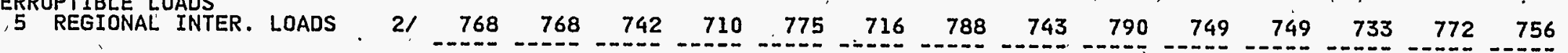

6 TOTAL LOADS $\quad \begin{array}{llllllllllllllll}30242 & 30249 & 29926 & 32225 & 34261 & 36800 & 37828 & 36698 & 34273 & 32525 & 32537 & 30656 & 30752 & 30426\end{array}$

HYDRO RESOURCES

7 REGULATED HYDRO

8 INDEPENDENT HYDRO

9 MAY WATER BUDGET

10 JUNE COL. RIVER FLOW AUG

II SUS. PKNG. ADJUSTMENT

12 TOTAL HYDRO

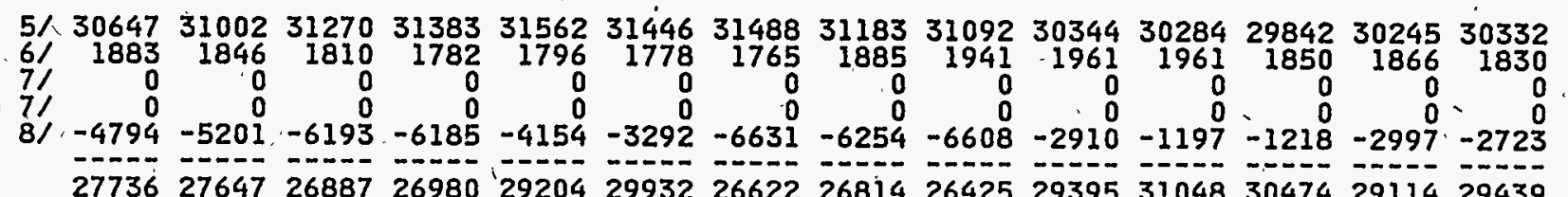

OTHER RESOURCES

13 SMALL THERMAL \& MISC

14 COMBUSTION

16 COGENERATION

17 IMPORTS

18 CENTRALIA

19 JIM BRIDGER ,

20 COLSTRIP 1

21 BOARDMAN

22 VALMY

24 WNP 2

25 COLSTRIP 4

26 FED RESOURCE ACQUIS

28 TOTAL RESOURCES

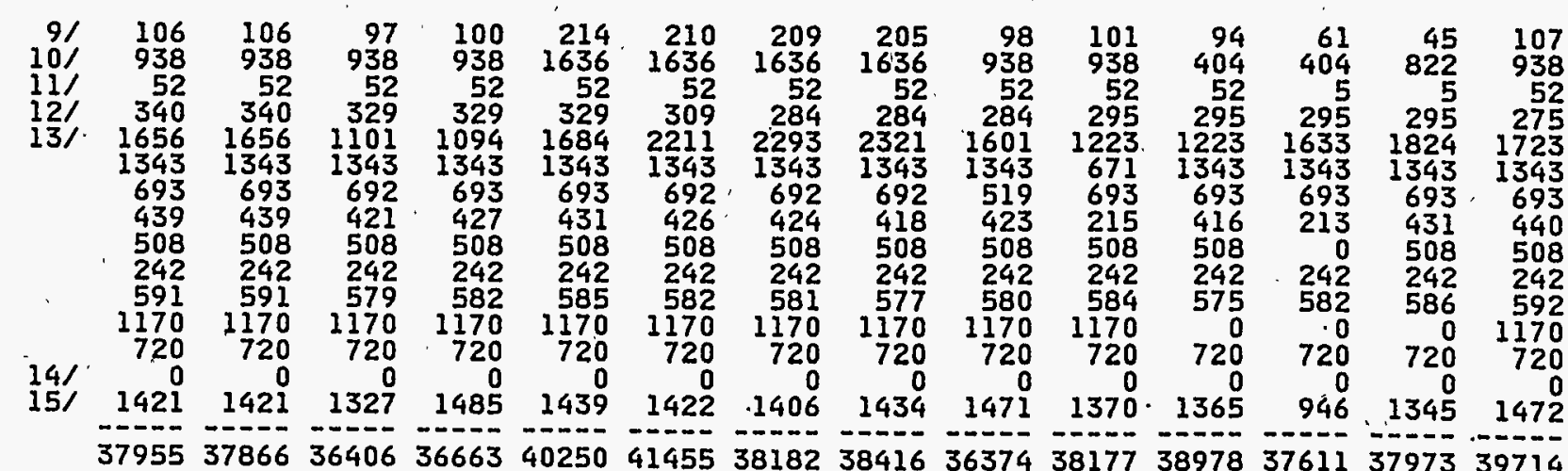

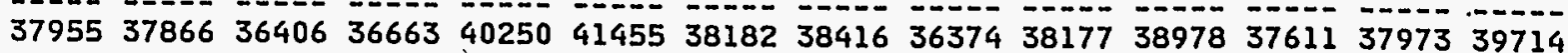


TABLE 1: PACIFIC NORTHWEST REGIONAL AREA

SUMMARY OF PACIFIC NORTHWEST REGIONAL LOADS AND RESOURCES

UNDER THE PACIFIC NORTHWEST ELECTRIC POWER PL ANNING AND CONSERVATION ACT ASSUMING NO NIGHTTIME RETURN CONSTRAINTS

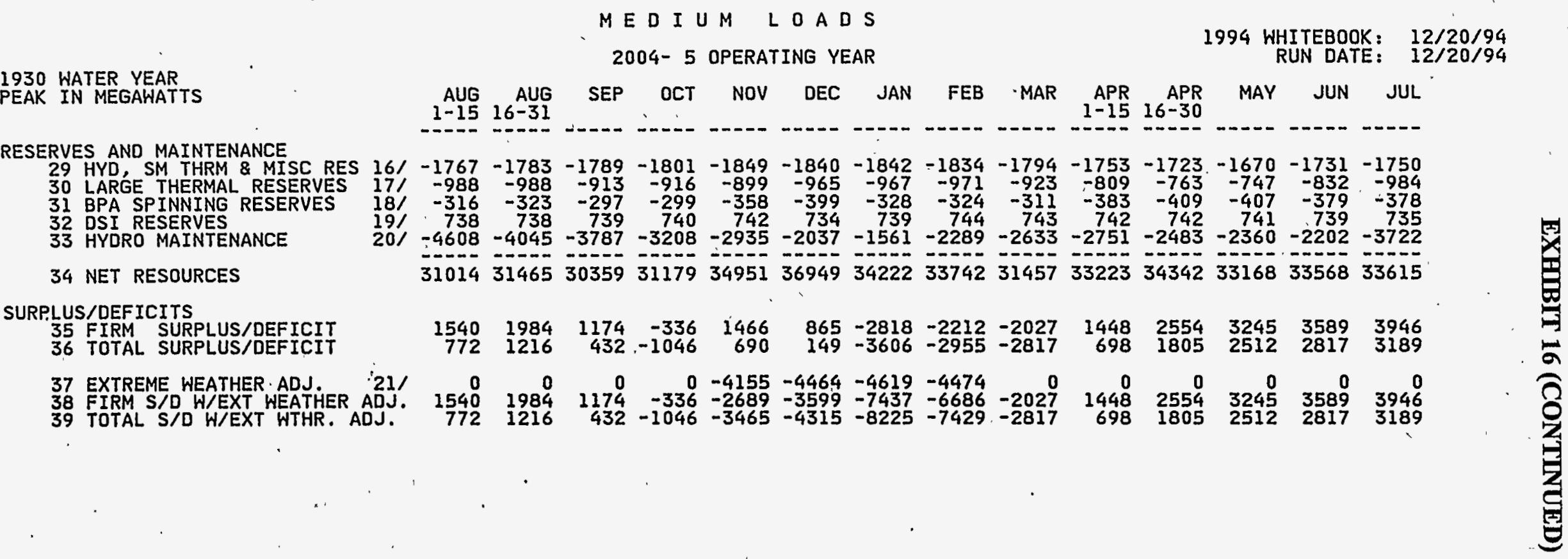




\section{REGIONAL FOOTNOTES}

\section{For Exhibits 9 through 16}

1. Firm loads for the region include the sum of the estimated firm loads of Federal agencies, public agencies, direct service industries (DSIs), investor-owned utilities (IOUs), and associated transmission losses. Peak loads represent non-coincidental capacity demands adjusted to account for Federal system diversity; they are based on the prediction of normal weather and have a 50-percent chance of being exceeded.

2: Total loads for the region include system firm loads, plus BPA's nonfirm loads, which include industrial top-quartile loads, associated transmission losses, and Utah Power. Company's interruptible load.

3. Exports from the region' by Northwest utilities include BPA's surplus firm power sales to the cities of Burbank, Glendale, Pasadena, Sacramento Municipal Utility District, San Diego Gas and Electric, and Southern California Edison; BPA's surplus firm power sale to M-S-R Public Power Agency, which converts to a capacity sale on November 1, 2009; BPA's capacity contracts with the cities of Anaheim and Riverside; BPA's 'capacity for exchange energy contracts with the cities of Anaheim, Pasadena, and Riverside; BPA's environmental storage agreement with Southern California Edison; BPA's optional capacity agreement with Southern California Edison; BPA's contract with BC Hydro for Canadian Entitlement beginning April 1, 1998; BPA's Northwest-Southwest Intertie losses; Idaho Power Company's power sales to Sierra Pacific, the cities of Azusa, Banning, and Colton in California, the city of Washington in Utah, and Utah Associated Municipal Power Systems (UAMPS); Montana Power Company's power sales to the Los Angeles Department of Water and Power; Pacific Power and Light's transfer to its Northern California load, and power sales to the California Department of Water Resources, Pacific Gas and Electric, Southern California Edison, Sacramento Municipal Utility District,' and the Western Area Power Administration (WAPA); Portland General Electric's power sales to the cities of Burbank and Glendale, Southern California Edison, and WAPA, and seasonal power exchange deliveries to Southern California Edison; Seattle City Light's seasonal power exchange deliveries to Pacific Gas and Electric; Puget Sound Power and Light's seasonal power exchange deliveries to Pacific Gas and Electric; Washington Water Power's seasonal power exchange deliveries to Pacific Gas and Electric; the City of Idaho Falls' contract with Utah Power Company for Gem State Hydro; Seattle City Light's seasonal power exchange deliveries to Northern California Public Agencies; and Snohomish County Public Utility District's seasonal power exchange with Sacramento Municipal Utility District, and Tacoma Public Utilities' power sale to WAPA.

Also included in exports are resources purchased by utilities outside the region. These include WAPA's purchase of the output of Longview Fibre, 14.2 percent of the 
Boardman coal plant sold to San Diego Gas and Electric, and 10 percent of the Boardman coal plant sold to the City of Turlock, CA.

4. Federal diversity is a percentage reduction applied to the Federal system non-coincidental peak utility allocation requirements. This is because all peaking electrical loads do not occur simultaneously throughout the region.

5. Regulated hydro includes those hydro dams where the firm energy generation of the dam is affected by the release of stored water from upstream reservoirs. Regulated hydro generation is determined by completing a hydro regulation study of the Pacific Northwest hydro system.

6. Independent hydro includes those hydro dams where no reservoirs exist upstream to release stored water and the firm energy is based on fixed historical flows. Hydro independents are not changed as a part of the hydro regulation study.

7. May Water Budget and June Columbia River Flow Augmentation is the energy loss due to the overgeneration which may be unusable as a firm resource on the Federal system due to the operation of the hydro system.

8. Sustained peaking adjustment is a percentage reduction applied to the Federal hydro system to meet a capacity load of 50 hours per week. This adjustment also includes reductions for Federal hydro maintenance, spinning reserves, forced outage reserves, and summer flow augmentation on the Lower Snake River and John Day hydro. projects.

9. Small thermal and miscellaneous resources include Tacorna Public Utilities' Steam Plant No. 2; Idaho Power Company's Energy Management System; Portland General Electric's Summit units; Puget Sound Power and Light's Crystal Mountain and Shuffleton; Montana Power Company's portion of Corette and Bird in the region; and Seattle City Light's Boundary.

10. Combustion turbines include Clark County Public Utility's Cogentrix; Idaho Power Company's Wood River; Portland General Electric's Bethel and Beaver; Puget Sound Power and Light's Whidbey Island, Whitehorn, Fredrickson, and Fredonia units; and Washington Water Power's Northeast units.

11. Renewables include Emerald County PUD's Short Mountain; and Washington Water Power's Kettle Falls.

12. Cogeneration includes Eugene Water and Electric Board's WEYCO Energy Center; Snohimish County PUD's Scott Paper; and Portland General Electric's Coyote Springs. Longview Fibre output is sold outside the region to WAPA.

13. Imports include exchange energy to BPA from the cities of Anaheim, Pasadena, and Riverside; exchange energy from the M-S-R Public Power Agency after their surplus firm sale converts to a capacity/energy exchange beginning November 1, 2009; deferred energy returns from Sacramento Municipal Utility District and San Diego Gas and Electric; exchange energy returned from San Diego Gas and Electric; power from Pacific Power and Light's Wyoming Division to serve BPA's Southern Idaho load; Power purchases from Basin Electric Cooperative and Powerex (TransAlta); seasonal power exchange deliveries to BPA from the cities of Pasadena and Riverside; environmental storage returns to BPA from Southern California Edison; Pacific 
Power and Light transfers from their Wyoming division and seasonal power exchange deliveries to Portland General Electric from Southern California Edison; power sale deliveries to Puget Sound Power and Light from BC Hydro, and seasonal power exchange deliveries from Pacific Gas \& Electric and from Puget Sound Power and Light to Seattle City Light; Utah Power Company's intra-company transfer; seasonal power exchange deliveries to Washington Water Power from Pacific Gas and Electric; power deliveries to Seattle City Light from BC Hydro for Ross replacement; seasonal power exchange deliveries from Northern California Public Agencies to - Seattle City Light; and BC Hydro's delivery of power to BPA for the Portland General Electric inter-company pool.

14. Resource acquisitions are resources BPA has identified and contracted for future purchase. When new Federal resource acquisitions are contracted for and/or on-line, they will be included in the loads and resources balance.

15. Non-utility generation (NUG) resources include generation provided to utilities by independent power producers and resources included under the Public Utility Regulatory Policies Act (PURPA). This study included 189 individual NUGs.

16. Hydro, small thermal and miscellaneous resources, and combustion turbine reserve requirements are estimated at 5 percent of the capacity of these resources for all utilities in the region.

17. Large thermal reserves requirements are estimated at 15 percent of the total capacity of the Pacific Power and Light thermal import into the region plus the large thermal resources owned by utilities in the region.

18. Federal spinning reserves equal the reserve generating capacity maintained to provide a regulating margin for the automatic generation and frequency control of power generation.

19. Direct service industry reserve requirements are estimated at one-third of the industrial firmload, or the sum of the reserve requirements for Federal hydro, small thermal and miscellaneous resources, combustion turbines, and large thermal; whichever is smaller.

20. Hydro maintenance is the sum of individual Federal system, public agency, and IOU hydro project maintenance, based on the average of the 1983-84 through 1988-89. schedules submitted to the Northwest Power Pool.

21. Extreme weather adjustment is the sum of all utility load responses with Pacific Northwest cold weather, and has a 5-percent chance of being exceeded. 
2

\section{SECTION IX} GLOSSARY 


\section{GLOSSARY}

Average Megawatts - A unit of electrical consumption or production over a year. It is equivalent to the energy produced by the continuous use of 1 megawatt of capacity served over a period of 1 year. (Equivalent to 8.76 gigawatt hours, 8,760 megawatt hours, or 8,760,000 kilowatt hours.)

Biomass - Any organic matter that is available on a renewable basis, including forest residues, agricultural crops and waste, wood and-wood wastes, animal wastes, livestock operation residue, aquatic plants, and municipal wastes.

Boiling Water Reactor (BWR) - A nuclear power plant in which stearn from the reactor is fed directly into the steam turbine.

Bonneville Power Administration (BPA) - BPA is a power marketing agency, responsible for acquiring and delivering sufficient power to meet its contractual obligations to serve the electrical needs of its customers. BPA does not own generating resources.

Calendar Year - Calendar year (CY) is the 12-month period January 1 through December 31. For example, CY 1994 is January 1, 1994 through December 31, 1994.

Capacity - The maximum power that an electrical system or machine such as a hydro powered or thermal powered generating plant can produce under specified conditions.

Capacity Factor - The ratio of the average load on a machine or piece of equipment over a given period to the maximum power rating of the machine or equipment.

Cogeneration - The simultaneous production of electricity and useful heat energy from a fuel source. Often this is accomplished by the recovery of waste energy caused by various industrial and commercial operations. This is typically used for industrial processes or space heating applications.

Columbia River Flow Augmentation (CRFA) - A part of the National Marine Fisheries Service Biological Opinion dated March 16, 1994, that calls for the storage of water in the winter for later release in the late spring in order to assist in the downstream migration of juvenile salmon and steelhead.

Conservation - Any reduction in electrical power consumption as a result of increases in the efficiency of energy use, production, or distribution.

Critical Period - That portion of the historical streamflow record during which the recorded streamflows, combined with all available reservoir storage, produced the least amount of energy.

Dedicated Resources - Generating resources owned by a utility and used to serve its firm loads. These resources are declared for a rolling 7-year period in Exhibit I of: the utilities' power sales contracts with BPA.

Direct Service Industries (DSI) - A group of industrial customers that: purchase electric power directly from BPA. Most DSIs are aluminum and other primary metal smelting plants.

Diversity - An adjustment applied to peak loads to reflect the fact that all peaking electrical demands do not occur simultaneously across the region.

Energy Load - The demand for power averaged over a specified period of time.

Federal Columbia River Power System (FCRPS) - The FCRPS consists of 30 Federal hydroelectric projects constructed and operated by the U.S. Army Corps of Engineers (COE), U.S. Bureau of Reclamation (USBR), plus BPA's transmission facilities.

Federal System - The Federal system is a combination of BPA's customer loads and contractual obligations, and resources from which BPA acquires the power it sells. The resources include plants operated by the U.S Army Corps of Engineers (COE), U.S. Bureau of Reclamation (USBR), and hydroelectic projects owned by the city of Idaho Falls and WPPSS. BPA markets the thermal generation from WNP-2, operated by WPPSS. 
50-Hour Peak Capacity - The amount of capacity that can be sustained for 10 hours a day during peak-load hours for a 5-day week.

Firm Capacity - Maximum on-peak electrical energy which is considered assurable to the customer to meet all contractual peak load requirements over a defined period.

Firm Energy - Electric power which is considered assurable to the customer to meet all contractual energy load requirements over a defined period.

Firm Energy Load Carrying Capability (FELCC) - The amount of electrical energy load that a hydro system could serve on a firm basis under critical-period streamflows.

Fiscal Year - In this study, fiscal year (FY) is the 12 month period October 1 to September 30. For example FY 1994-95 is October 1, 1994 to September 30, 1995.

Forced Outage Reserve - Capacity that is held in reserve, for use in case a generating unit malfunctions.

Forced Energy Sale (Spill) - Electrical energy that cannot be accepted into the system and must either be sold or spilled due to constraints and limitations of hydro projects.

Forebay - The portion of the reservoir at a hydroelectric plant that is immediately upstream of the generating station.

Historical Streamflow Record - The unregulated streamflow database of the 50 years from July 1928 to June 1978.

Hydroregulation - A study simulating operation of the Pacific Northwest electric power system that incorporates the historical streamflow record, monthly loads, thermal and other non-hydro resources, hydroelectric plant data for each project, and the constraints limiting each project's operation.

Interruptible Loads - Loads that can be interrupted in the event of a power deficiency on the supplying system.

Megawatts - A unit of electrical power equal to 1 million watts or 1,000 kilowatts.

Model Conservation Standards (MCS) - A set of energy-efficient building standards for new electrically heated commercial and residential buildings. It also includes standards for residential and commercial buildings that have been changed to electric space heating.

Nondedicated Resources - Resources brought into service after June 1980 by BPA customers who choose not to use them to serve their own firm loads.

Nonfirm Energy - Electrical power produced by the hydro system that is available with water conditions better than those of the critical period without appreciably jeopardizing reservoir refill. It is available in varying amounts depending upon season and weather conditions.

Nonfirm Energy Loads - Loads that are served with nonfirm energy whenever it is available.

Obligation - Capacity and energy the Federal system is required to provide to public agencies and IOUs under their power sales contracts with BPA.

Operating Year - For this study, operating year (OY) is the 12-month period August 1 through July 31. For example, OY 1994-95 is August 1, 1994 through July 31, 1995.

Peak Load - The maximum demand for power during a specified period of time.

Programs In Perspective ,- An annual program conducted by BPA to take the agency's proposed programs and budgets before the public, both to explain the agency's plans and to get constructive feedback.

PURPA Resources - Resources declared by utilities according to the Public Utility Regulatory Policies Act of 1978 (Public Law 95-617).

Region - The geographic area defined by the Pacific Northwest Electric Power Planning and Conservation Act. It includes Oregon, Washington, Idaho, Montana west of the Continental Divide, portions of Nevada, Utah, and Wyoming that lie within the Columbia River drainage basin, and any nural electric cooperative customer not in the geographic area described above but served by BPA on the effective date of the Northwest Power Planning Act.

Resource Acquisitions - Conservation or generating resourcès acquired in order to meet projected firm energy deficits.

Spinning Reserves - Reserve generating capacity which is maintained for immediate response to load variations. This provides a regulating margin for controlling the automatic generation and frequency of power in the Federal system. 
Surplus Firm Capacity - The maximum amount of assured electrical power above the firm peak loads served by the power-system.

Surplus Firm Energy - The amount of assured electrical energy above the firm energy loads served by the power system.

Sustained Peak - The peaking capacity necessary to sustain a load for a given period of time.

Water Budget - A part of the Pacific Northwest Power Planning Council's Fish and Wildlife Program that calls for a quantity of water to be released in order to assist in the downstream migration of juvenile salmon and steelhead. 